\title{
Upper thermal threshold of Lepidurus arcticus (Branchiopoda, Notostraca) in lakes on the southern outreach of its distribution range
}

\author{
Tore Qvenild, Eirik Fjeld', Arne Fjellheim ${ }^{3}$ Johan Hammar, Trygve Hesthagen ${ }^{5}$ and Hanna-Kaisa Lakka,
}

\author{
Qvenild T, Fjeld E, Fjellheim A, Hammar J, Hesthagen T and Lakka H-K. 2021. Upper thermal threshold of \\ Lepidurus arcticus (Branchiopoda, Notostraca) in lakes on the southern outreach of its distribution range. Fauna \\ norvegica 41: 50-88.
}

\begin{abstract}
The Arctic tadpole shrimp Lepidurus arcticus has a circumpolar distribution and the Scandes (Fennoscandian Mountains) marks its southernmost limit in Europe. Within this area, 391 natural and 88 regulated lakes with L. arcticus have been identified, of which $87 \%$ are above the treeline. The lakes hosting L. arcticus decrease in altitude from south to north, which results from its temperature preferences. The majority of the locations are at a lower lake air temperature than $11^{\circ} \mathrm{C}$ which is equivalent to a water temperature near $14^{\circ} \mathrm{C}$. This is assumed to be near the upper thermal threshold for L. arcticus. In lakes that exceed this average summer water temperature (1 July - 15 September), sustainable populations seem to be rare. In warmer lakes, life cycle mismatches are assumed to explain the absence of $L$. arcticus, most likely by affecting the embryo and juvenile stages. The distribution appears to be dichotomous, with one large northern area north of $65^{\circ} \mathrm{N}$ and one separated southern "island". Only two locations of $L$. arcticus are known for the area between latitudes 62.88 and $64.39^{\circ} \mathrm{N}$. In this part of the Scandes, the lakes are likely too warm to host $L$. arcticus as most of them are situated below $700 \mathrm{~m}$ a.s.l. This may also be the case in the northernmost region, north of $70^{\circ} \mathrm{N}$, where only 11 populations are recorded. Most of the lakes in this area typically occurs below $400 \mathrm{~m}$ a.s.l. L. arcticus populations are sensitive to fish predation, and dense fish populations may be another stressor limiting its distribution. In contrast to water bodies in the High Arctic where L. arcticus only exists in shallow, fishless ponds, in the Scandes they co-exist with fish in $97 \%$ of the findings. Global warming has already modified the environment of the Scandes, and populations of $L$. arcticus are at threat in many of the small and shallow water bodies at low altitudes.
\end{abstract}

doi: 10.5324/fn.v4li0.3832. Received: 2020-11-17. Accepted: 2021-07-04. Published online: 2021-12-07. ISSN: $1891-5396$ (electronic).

Keywords: Arctic tadpole shrimp, Scandes, Fennoscandian mountain ridge; distribution, thermal conditions, upper thermal threshold, life cycle mismatch, treeline, climate indicator, climate change

1. County Governor of Innlandet, Statens hus, Parkgata 36, NO-2317 Hamar, Norway

2. Fjeld og vann AS, Terrasseveien 31A, NO-1363 Høvik, Norway

3. NORCE Norwegian Research Centre AS, Nygårdsgaten 112, NO-5008 Bergen, Norway

4. Institute of Freshwater Research, Stångholmsvägen 2, SE-178 93 Drottningholm, Sweden

5. Norwegian Institute for Nature Research (NINA), PO Box 5685, Torgården, NO-7485 Trondheim

6. Department of Biological and Environmental Science, University of Jyväskylä, P.O. Box 35, FI-40014 Jyväskylä, Finland

7. Kilpisjärvi Biological Station, Faculty of Biological and Environmental Sciences, University of Helsinki, P.O. Box 4, Yliopistonkatu 4, FI-00100 Helsinki, Finland

Corresponding author: Tore Qvenild

E-mail: fmhetq@fylkesmannen.no

\section{INTRODUCTION}

Climate change over broad temporal scales has affected the distribution and composition of the regional vegetation in many areas, and an increasing treeline has proved to be a good indicator of long-term climate change (Dahl \& Nesje 1996). The treeline in the Fennoscandian Mountain Ridge $\left(59\right.$ to $\left.71^{\circ} \mathrm{N}\right)$, also known as the Scandes, was far above the present treeline in early-to mid-Holocene (7600-4500 BP). From reconstructions of the treeline, the temperature in that period may roughly have been $1.5-2^{\circ} \mathrm{C}$ higher than at present
(1961-1990). The warm period in early-Holocene may be regarded as an early analogue for the increased precipitation and temperature that is projected towards the end of the century (Hanssen-Bauer et al. 2017).

Ecological sensitivity is high in mountain habitats, where many species live at the threshold of their tolerance and thus close to their geographical limit (Lindholm et al. 2015). Lepidurus arcticus (Pallas, 1793) is a cold adapted Branchiopod species (Figure 1) with a circumpolar distribution (Rogers 2001; Hessen et al. 2004; Lakka 2013). Protracted warm periods may be problematic for $L$. arcticus in 


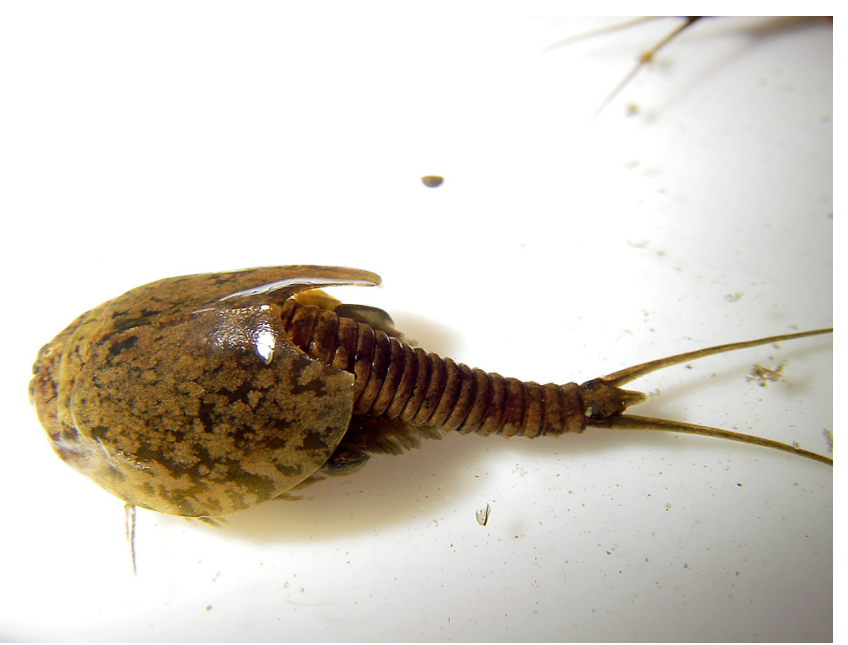

Figure I. The Arctic tadpole shrimp Lepidurus arcticus is a large ( $2-4$ $\mathrm{cm})$ cold-water adapted species which mainly occurs in lakes above the treeline in the Scandes. Photo: Hanna-Kaisa Lakka.

Scandes which marks the southernmost part of its distribution range in Europe (Sømme 1934; Økland \& Økland 2003). This may result in a range retraction of the species, as has already been experienced by another Branchiopod species, the Branchinecta palludosa O.F.Müller, 1758 (Lindholm et al. 2012, 2015).

Branchiopoda without cladocerans are commonly known as the "large branchiopods" (Brendonck et al. 2008). The order Notostraca is composed of the family Triopsidae and includes two genera (Triops and Lepidurus) of "living fossils" which have undergone minimal gross morphological change since their divergence over 250 million years ago (Longhurst 1955). Lepidurus arcticus (Figure 1) is one of these large branchiopods. Evidence of this "living fossil" has been found in lake sediments. For example, remains have been found inside the skull of a mammoth that lived during the ice age approximately 39000 BP (Neretina et al. 2020).

All the crustacean groups inhabiting temporary water bodies have evolved means to survive periods of desiccation and freezing. The production of resistant or diapause eggs that can withstand such harsh conditions has enabled successful invasion and colonization of these habitats (Longhurst 1955). The dry eggs can remain viable for decades without re-hydration (Donald 1983; Belk 1988, cited in Brendonck et al. 2008; Hann \& Lonsberry 1991). However, drying or freezing is not mandatory. In practically all Brachiopoda, it is common to have both dormant and subitaneous embryos (Hann \& Lonsberry 1991).

Lepidurus arcticus has a univoltine life cycle emerging from the resting eggs at snow melt and fulfils its development during a short mountain summer, before they reproduce and cease (Sømme 1934). The development and growth from hatching to adults has proved to be highly dependent on water temperature (Qvenild et al. 2018).

Distribution of L. arcticus in the Scandes, occurs near sea-level in the northernmost region, and at progressively higher altitudes towards the south (Sømme 1934; Økland \& Økland 2003). This distribution pattern has mainly been explained by their temperature preferences (Sømme 1934; Aass 1969; Økland \& Økland 2003). However, colonization history, water quality and snow deposition may also limit its distribution (Lingdell \& Engblom 2002; Qvenild \& Hesthagen 2019).

The optimal temperature of $L$. arcticus is approximately $10^{\circ} \mathrm{C}$ (Lakka 2013). This is met in Arctic conditions only for short periods but may frequently be experienced in Scandes lakes. As an adult, $L$. arcticus tolerates temperatures from $1.8^{\circ} \mathrm{C}$ (Lakka 2013) up to $19^{\circ} \mathrm{C}$
(Arnold 1966), although water temperature may be higher for short duration exposures (Borgstrøm 2019). For the juvenile stages, the upper lethal limit appears to be lower than $15^{\circ} \mathrm{C}$ (Pasquali et al. 2019).

Temperature drives the biological processes needed for fulfilling a life cycle. This input has often been expressed in terms of cumulative thermal units as degree-days (Bottrell 1975), being equivalent with the average water temperature in a specific period. Although L. arcticus may tolerate a wide range of temperatures, the lower altitudinal limit of lakes hosting $L$. arcticus clearly indicate that the thermal input at some level may be too high. Our main intention in this study is to outline the distribution of $L$. arcticus throughout the Scandes and correlate it with local thermal conditions. This may give some indication of its upper thermal threshold. As L. arcticus mainly occur in lakes situated in the Alpine or sub-Arctic zones in the Scandes (Sømme 1934; Økland \& Økland 2003), its distribution can also be related to the treeline which throughout the mountain ridge are limited by birch (Betula pubescens), roughly following the $10^{\circ} \mathrm{C}$ July isotherm (Odland 1996).

Acquisition of thermotolerance data for organisms is essential, not only to determine the role of temperature related to reproduction, growth and survival, but also to predict the consequences of global warming to vulnerable cold-water adapted species like L. arcticus. A changing climate affects the species-specific extinction risk for L. arcticus (Lakka 2020). Thus, global warming imposes thermal risks that need to be studied from a species perspective in their natural habitats.

\section{METHODS AND MATERIAL}

The Scandes run through the Scandinavian Peninsula. To the north, they form the border between Norway and Sweden, just touching the north-western part of Finland. The fact that the central mountain ridge borders the coastline of Norway, makes the rivers draining to the west and north into the North Atlantic Ocean short, steep and violent, in comparison to the long and gentle rivers draining to the east and south into the distant Baltic Sea (Hammar 2002). The mountain range has a length of ca $1700 \mathrm{~km}$, measured from Stavanger to the Varanger Peninsula in the north $\left(59-70^{\circ} \mathrm{N}\right)$, and a width of ca 320 $\mathrm{km}$ at its broadest span between Kristiansund and Hamar $\left(8-11^{\circ} \mathrm{E}\right)$. Its vast high plateaus and huge mountain massifs with alpine relief are deeply gouged by glaciers and numerous rivers draining in all cardinal directions. The mountain range creates a rain shadow of which the eastern part is considerably drier than the western part. In the area where the Arctic tadpole shrimp L. arcticus, occur, the yearly precipitation varies from more than $2800 \mathrm{~mm}$ on the western side of the mountains to less than $400 \mathrm{~mm}$ on the eastern fells. In most areas, the mountain range is situated above the treeline. The upper limit of birch (Betula pubescens) is some 150-200 m above the treeline for conifers (Dahl \& Nesje 1996), also going farther north.

In this paper, we use the term "Lepidurus lake" as a lake of any size, hosting $L$. arcticus also including regulated lakes. However, analysing the thermal conditions met in L. arcticus populations we only use natural lakes as temperature conditions are highly impacted by the management regime in the regulated ones (see Aass 1969).

Winter precipitation is calculated for the period (1 October - 30 April) as a mean for the normal period (1961-1990) by the NEVINA procedure (NVE Atlas, nve.no) for most of the Norwegian lakes along the transect and interpolated to nearby locations for the rest. For the Swedish area which are located near the Norwegian border, we have used the values from the nearest Norwegian locality. For the 
Finnish Lepidurus lakes we have used values from the meteorological station Kilpisjärvi Kyläkeskus for the period 1978-1989 (https:// en.ilmatieteenlaitos.fi/). Finnish and Swedish Lepidurus lakes have in general low winter precipitation $(<500 \mathrm{~mm})$.

\section{Mapping of the distribution}

Most of the records are from stomach analyses of fish as this has proved to be far the most effective method to detect the presence of L. arcticus, especially when it appears in low numbers and/ or has a patchy distribution (Fjellheim et al. 2007; Qvenild \& Hesthagen 2019). Other methods used to detect $L$. arcticus have included traditional methods as bottom samplers, plankton sieves and benthic littoral kick samples.

The Norwegian Biodiversity Information Centre (NBIC), offers a detailed, national coverage of L. arcticus (https://www. artsdatabanken.no). Most of these records were presented in Økland \& Økland (2003). Similar records are available (https://bioatlas.se) from the Swedish Biodiversity Data Infrastructure (SBDI). For Finland we used information given by different authors (Koli 1957; Järvinen et al. 2014; Lakka et al. 2019; Lakka 2020). We have updated these datasets processing a vast amount of scientific and pertinent literature in addition to own observations. All the records are given in Appendix 1.

\section{Air and water temperatures in the Scandes}

The normal period refers to the standard reference period (19611990) set by the World Meteorological Organization (WMO). Such data is delivered by the Norwegian and Finnish national net of meteorological stations (https://met.no/; https://ilmatieteenlaitos.fi/). Daily air temperatures were obtained from the same stations. We have used data from eight meteorological stations throughout the Scandes (Table 1, Figure 2) situated 72 to $973 \mathrm{~m}$ a.s.l.

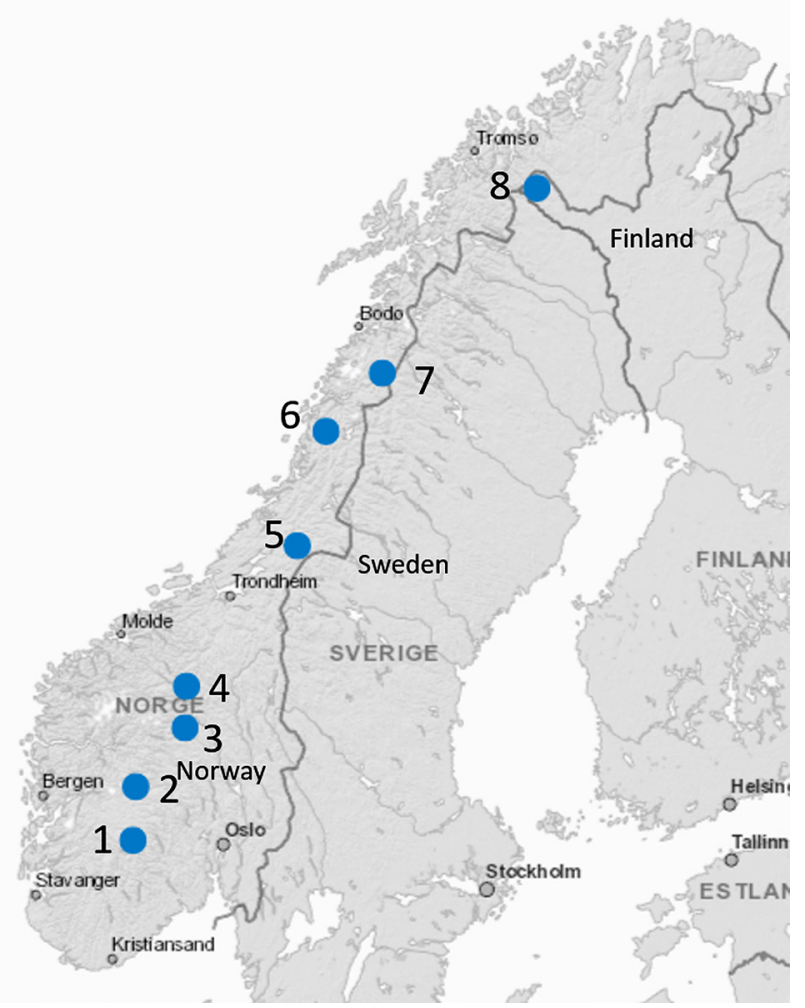

Figure 2. Location of the eight meteorological stations providing temperature data (1 Møsstrond; 2 Geilo-Olderbråten; 3 Skåbu; 4 Fokstugu; 5 Snåsa; 6 Mosjøen lufthavn; 7 Saltfjellet; 8 Kilpisjärvi Kyläkeskus). Norwegian Mapping Authority CC BY 4.0.

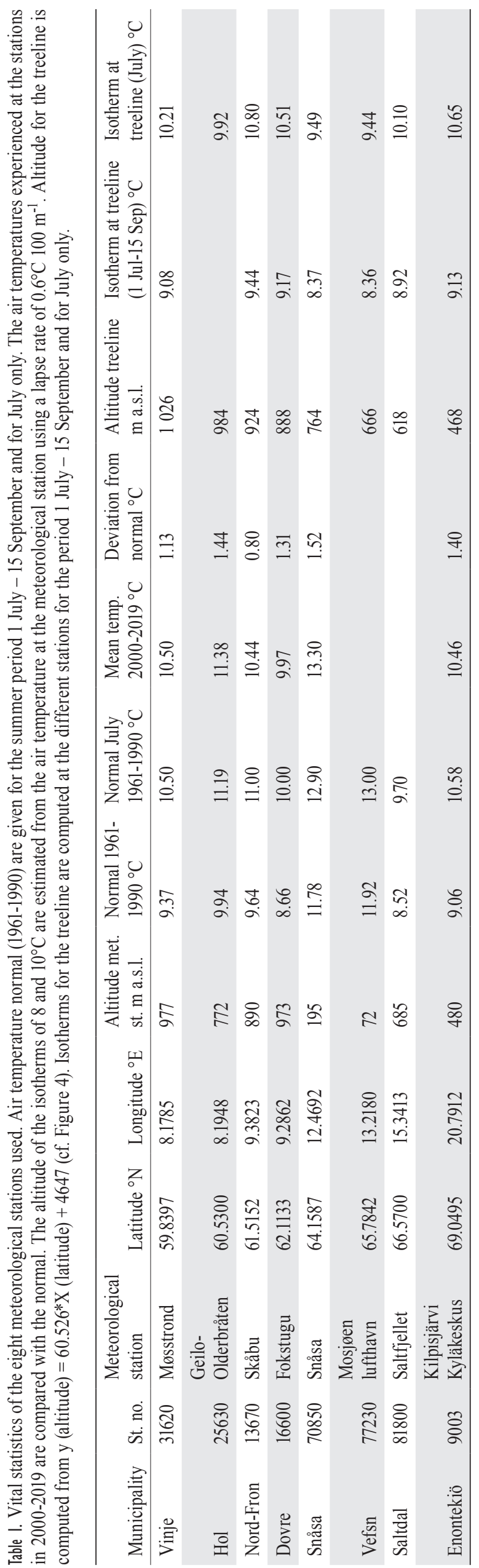




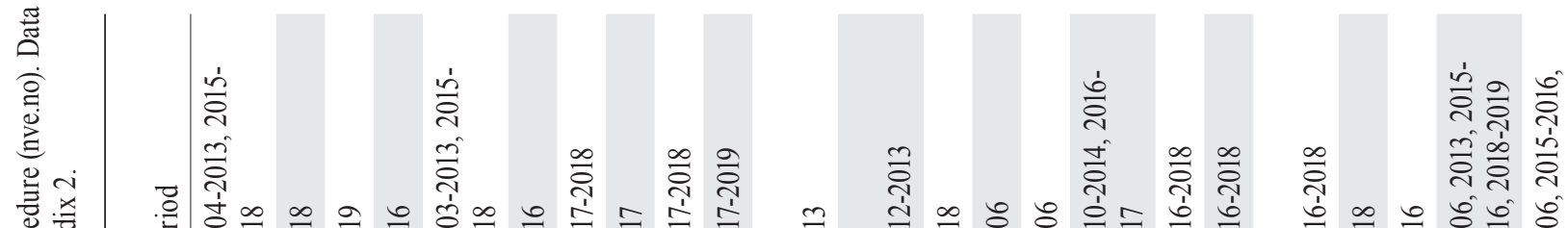

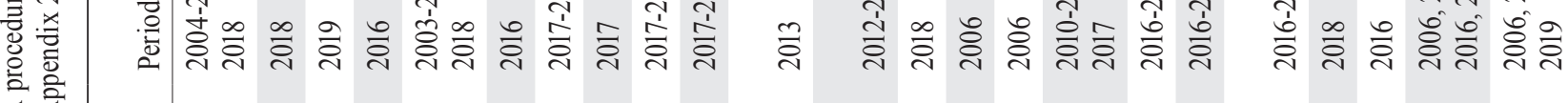

岩岸

穵

承

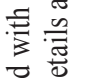

递苍

鸪

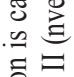

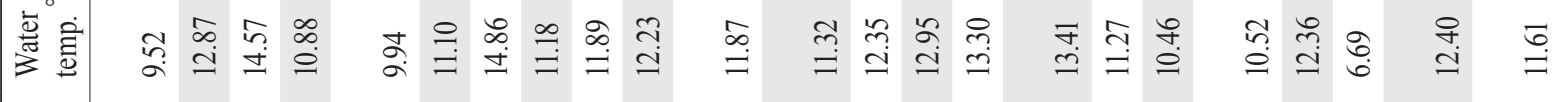

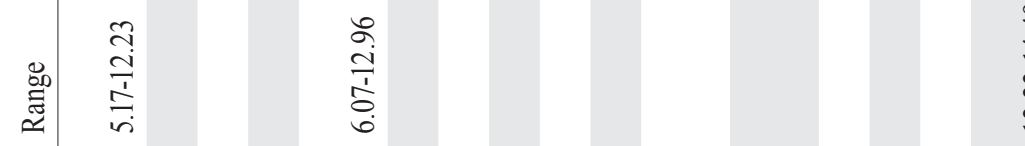

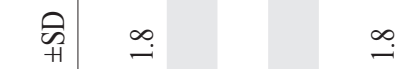

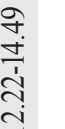

密惫

总,

离莣

3

递

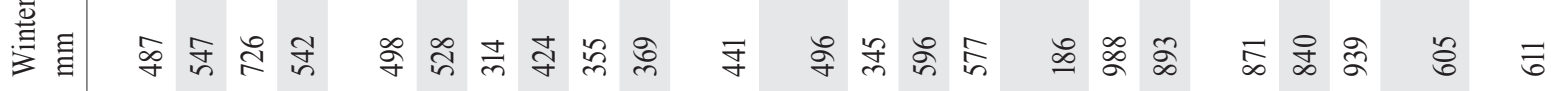

焉

旁帘

竞

主焉

:

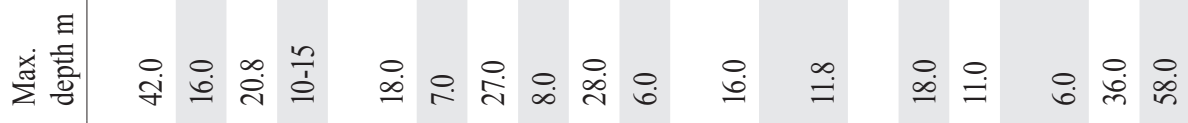

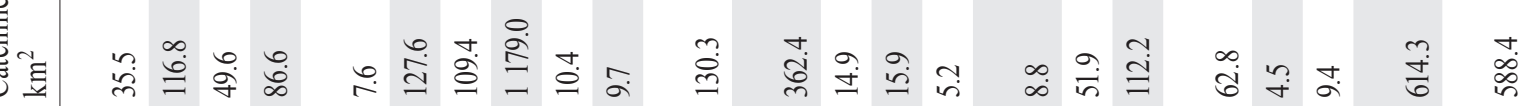

它

志

苍

호욜

$\frac{8}{0}$

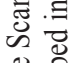

吾

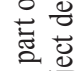

产

䓂 密

을

约

范

들

ํํㅇㅎำ

임

苛

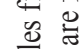

焉

可

密蓄

를

离完

空

当

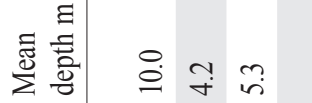

$\stackrel{\infty}{+} \uparrow$

aे

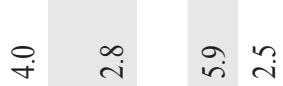

$\underset{\infty}{\infty} \stackrel{\infty}{=}$

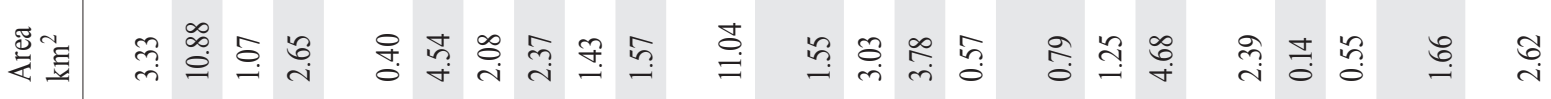

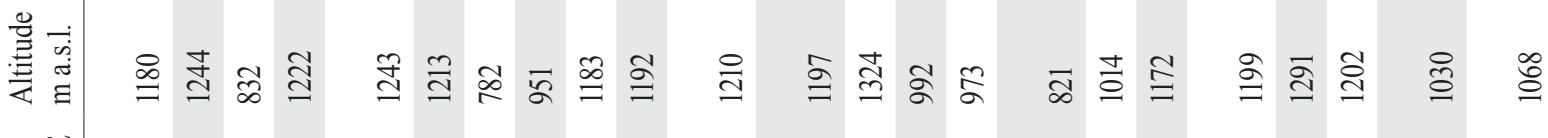
띠

䒿

:

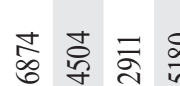

索究

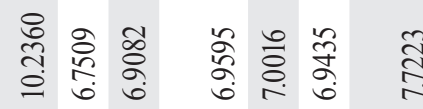

惫

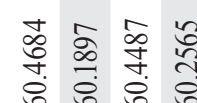

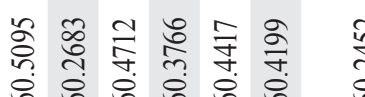

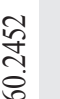

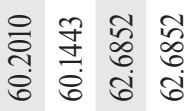

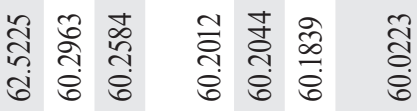

窝

言

홈

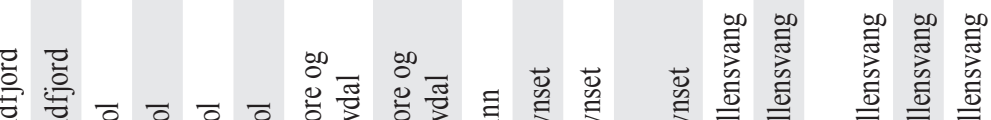

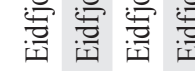

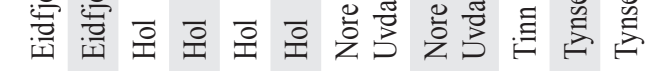

怘总离

竞高竞

$\stackrel{\circ}{?}$

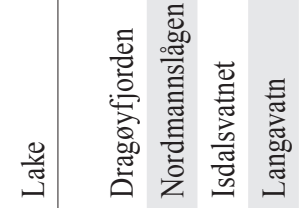

志

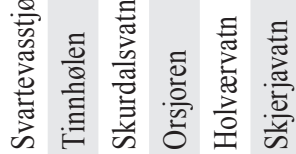

$\stackrel{\circ}{9}$

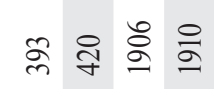

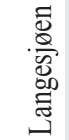

离

है 


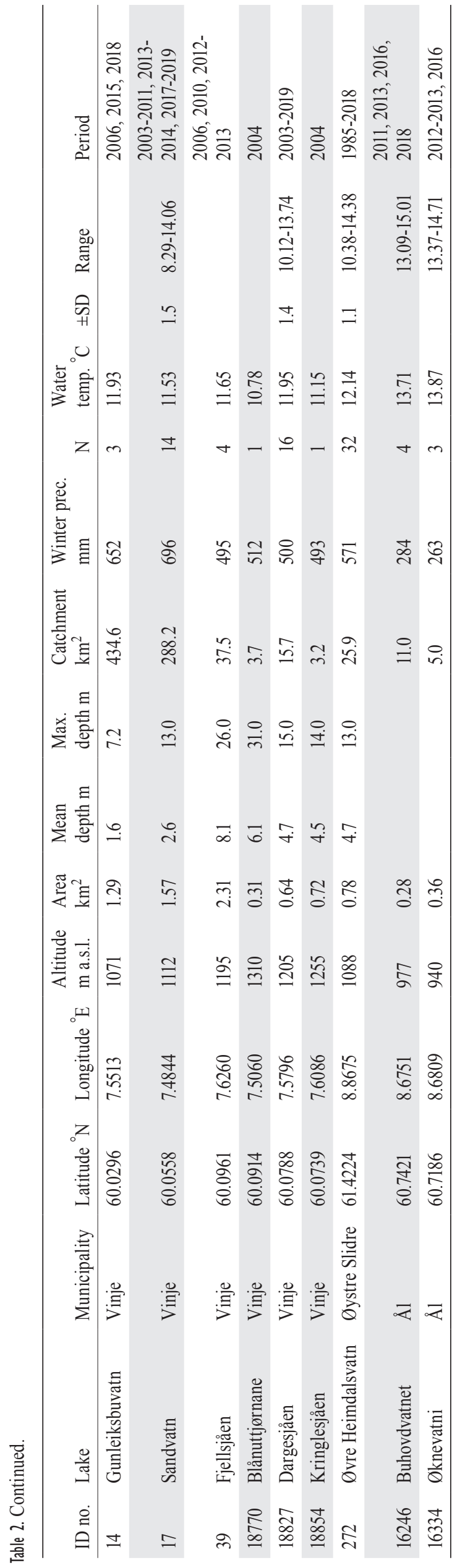

Continuous daily monitoring of water temperature data is available for only a limited number of lakes in the Scandes. Lake Øvre Heimdalsvatn has been surveyed since 1958 (Brittain \& Borgstrøm 2010) and after 1985 water temperature has been measured (Hydra II, nve.no). In addition, we have used own observations from 31 Norwegian lakes in the southern part of the Scandes during the period 2003-2019. Most of the lakes are situated at the Hardangervidda mountain plateau $\left(59.9-60.6^{\circ} \mathrm{N}, 6.9-8.4^{\circ} \mathrm{E} ; 832-1386 \mathrm{~m}\right.$ a.s.l.) which provides a wide range of different climatic conditions (see Qvenild \& Hesthagen 2019). In total, water temperatures are available from 32 lakes, representing 153 average summer values (Table 2, Appendix 2). Lepidurus arcticus is recorded in 26 of the lakes (Appendix 2). The six lakes without $L$. arcticus were included to strengthen the correlation between lake air temperature and water temperature in mountain lakes.

In this context, the summer period was defined to be 1 July - 15 September as most of the temperature loggers have operated continuously in this period. The surface water temperature (subsequently referred to as water temperature) was obtained by temperature loggers (mainly the Hobo UA-002-64) which were placed in the littoral zone at 1-3 m depth. In a few lakes, temperature loggers were also placed in the profundal zone. Hence, water temperature and lake air temperature refer to an average for the period 1 July -15 September.

The air temperature is lowered by a linear adiabatic lapse rate with increasing altitude. The lapse rate may vary with topography, regional and temporal climatic variables, variable altitudinal range and for temperature variability (Odland 1996). Laaksonen (1976) calculated a general lapse rate in Fennoscandia based on data from 612 meteorological stations. Regression between altitude and mean July temperature provided a lapse rate of $0.57^{\circ} \mathrm{C} 100 \mathrm{~m}^{-1}\left(\mathrm{R}^{2}=0.90\right)$. Data from 40 meteorological stations in the Swiss Alps revealed

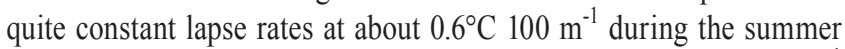
(Livingstone et al. 1995). An approximate lapse rate of $0.6^{\circ} \mathrm{C} 100 \mathrm{~m}^{-1}$ is widely accepted for the summer season in Fennoscandia (Odland 1996; Dahl \& Nesje 1996; Kvambekk \& Melvold 2010) and hence, we assume this to be a good proxy to calculate air temperature at the specific lakes.

The air temperature at the meteorological stations were transformed to isotherms along the Scandes by using this lapse rate. Further, these data were used to estimate the air temperature (later noted as lake air temperature) at the 32 lakes represented with water temperature profiles. For the specific meteorological stations, the air temperature normal, using the average daily temperature (1 July - 15 September) for the period 1961-1990, are provided (Table 1). This was used to estimate the altitudes $\left(\mathrm{Alt}_{10}{ }^{\circ} \mathrm{C}\right)$ where the air temperature is $10^{\circ} \mathrm{C}$ at the specific latitudes (Lat) of the meteorological stations. The $10^{\circ} \mathrm{C}$ isotherm is given by the regression line:

$\mathrm{Alt}_{10^{\circ} \mathrm{C}}=-64.229 * \mathrm{Lat}+4698.4$

From this regression $\left(\mathrm{R}^{2}=0.91\right)$, the lake air temperatures normal at the specific lakes were calculated. From the latitude of the lake, we calculated $\mathrm{Alt}_{10^{\circ} \mathrm{C}}$ and adjusted this to the real altitude of the lake by using the lapse rate $0.6^{\circ} \mathrm{C} 100 \mathrm{~m}^{-1}$.

To provide data from a lake where we could have expected $L$. arcticus but where it is not found, we included Lake Skurdalsvatnet (782 $\mathrm{m}$ a.s.l.) at the eastern fells of Hardangervidda (Table 2). In the early 1900s, the lake was thoroughly studied focusing on brown trout and its food organisms. The lake was surveyed at 21 occasions through seven years "without finding the least trace of the organism", i.e. 
L arcticus (Dahl 1917, 1926, 1932). In the upstream lakes, L. arcticus was the main food item for brown trout. This pattern was confirmed by new surveys in 1974 and 1975 (Amundsen 1976). We hypothesize Lake Skurdalsvatnet to be too warm for $L$. arcticus and thus, this particular lake may give an indication of the upper thermal threshold of the species. We used the meteorological station 25720 Haugastøl (996 $\mathrm{m}$ a.s.l.) $24 \mathrm{~km}$ northwest to the lake, to estimate the lake air temperature for summers before 1975 .

\section{Statistical methods}

The non-linear relationship between lake air temperature and water temperature for 26 lakes with Lepidurus and 6 lakes without were modelled with cubic splines (lambda $=4$ ), and $95 \%$ confidence bands for the curves were estimated from bootstrapped samples (random sampling with replacements, 1000 samples).

For five of the Lepidurus lakes we have numerous data on lake air and water temperatures (n: 14-39), which allowed us to give a closer statistical analysis of their relationship. Hence, we performed an analysis of covariance (ANCOVA) with water temperature as the response variable and lake air temperature (log-transformed), lake and their interactions as predictors.

The probability of the Lepidurus lakes to be situated above or beneath the tree line was modelled with a nominal logistic model with altitude and latitude as predictor variables.

We used the statistical program JMP (v. 15.2.0, SAS Institute Inc. 2019) for these analyses.

\section{RESULTS}

\section{Geographic distribution of Lepidurus arcticus in the Scandes}

Lepidurus arcticus has been recorded in 479 lakes in the Scandes mountains, covering latitudes $59.48-70.74^{\circ} \mathrm{N}$ and elevations $74-1524$ m a.s.l. (Figure 3, Appendix 1). Norwegian locations, ranging both further south and north than those in Sweden and Finland, dominate the dataset. On the Norwegian mainland, 315 and 79 are natural and regulated lakes, respectively. On the Swedish side, 78 locations were recorded, of which eight are regulated. In Finland, L. arcticus was found in six lakes and one small pond of which one is regulated (Lake Inarijärvi). Although Lake Inarijärvi, is not considered part of the Scandes, it was included in this material.

The geographic distribution of natural lakes covers two major alpine areas; one vast northern area with 167 records north of $64.39^{\circ} \mathrm{N}$, and the other in the south with 222 locations (59.48 to $\left.62.87^{\circ} \mathrm{N}\right)$. The natural Lepidurus lakes recorded in the southernmost part of the Scandes were situated at altitudes from 489 to $1524 \mathrm{~m}$ a.s.l. Between 62.88 and $64.5^{\circ} \mathrm{N}$, only two natural lakes with $L$. arcticus are known, both situated in Sweden. In this area, few mountains reach altitudes above $700 \mathrm{~m}$ a.s.l. In the northernmost part, north to $70^{\circ} \mathrm{N}$, only 11 natural lakes where located, all at altitudes below $327 \mathrm{~m}$ a.s.l. In this area, the mountains are barely hills, few reaching more than $400 \mathrm{~m}$ a.s.l. (Figure 4). The altitudes of the natural lakes with L. arcticus thus decline towards the north. Information of lake depths are only known from 78 natural lakes (Appendix 1). The deepest lake has a maximum depth of $77 \mathrm{~m}$. Of these limited numbers of lakes, $30 \%$ are shallower than $10 \mathrm{~m}$ and $60 \%$ are shallower than $20 \mathrm{~m}$. Consequently, most of the lakes must be characterized as relatively deep lakes.

Most of the Swedish records of $L$. arcticus were found in northern river-systems known to contain numerous natural fish-free head-water lakes. All the natural Finnish Lepidurus lakes are from the north-

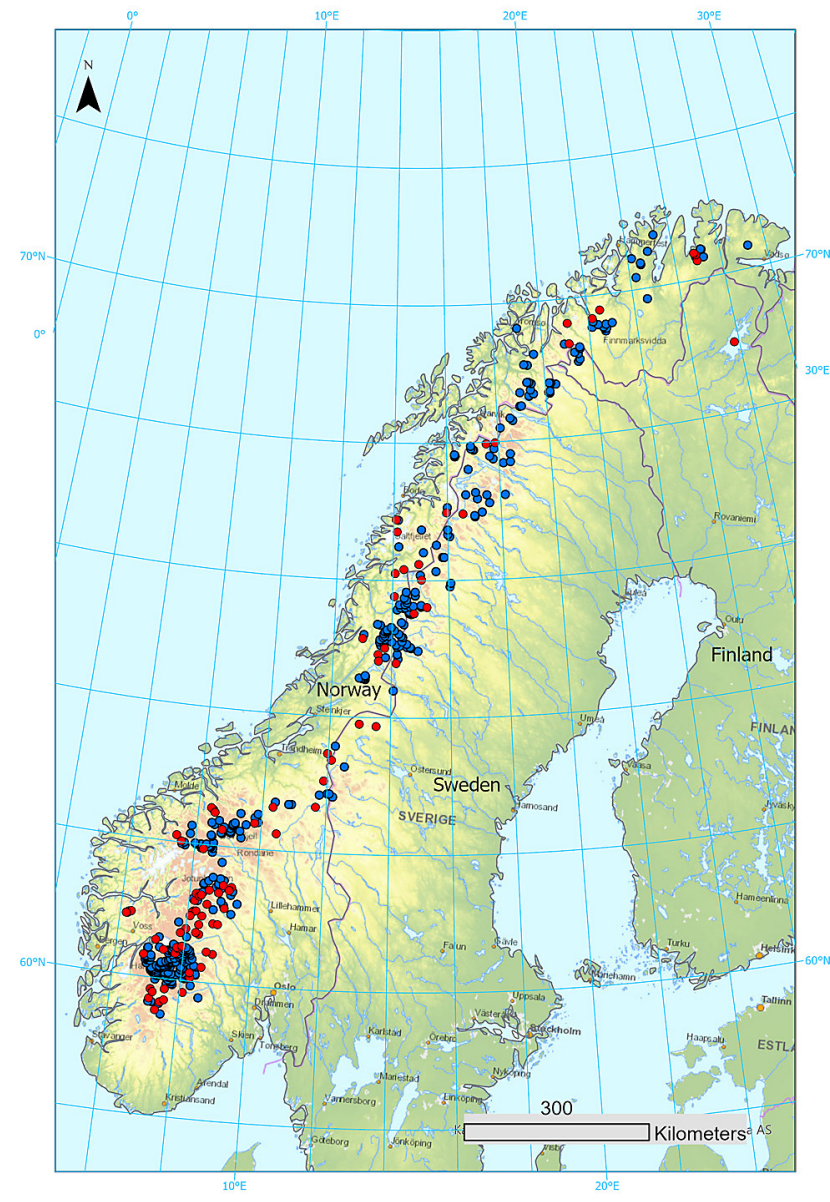

Figure 3. Distribution of 479 lakes hosting Lepidurus arcticus in the Scandes. Natural lakes (391) are indicated by blue dots and regulated lakes (88) with red dots. Norwegian Mapping Authority CC BY 4.0.

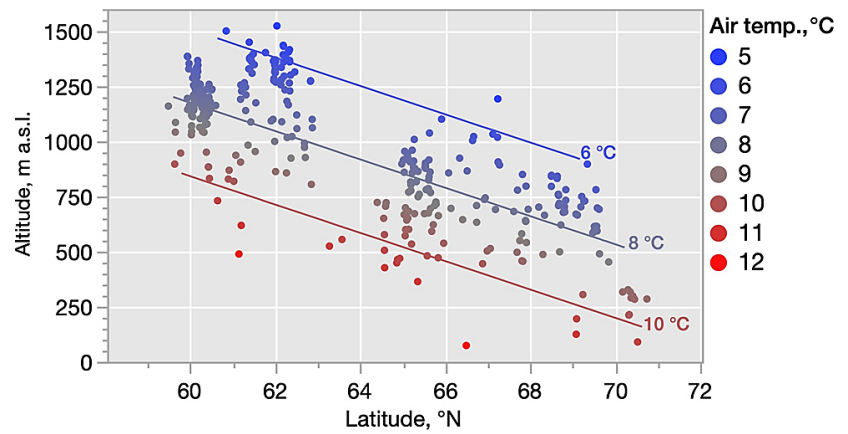

Figure 4. Contour plot of average summer (1 July - 15 September) lake air temperature, latitude and altitude for 391 lakes with Lepidurus arcticus. A central tendency in the lake distribution is that they are spread around the $8^{\circ} \mathrm{C}$ isotherm in the plot. Air temperatures are indicated by a continuous colour scale (blue - gray -red)

western part of Finnish Lapland in the municipality of Enontekiö. In addition, $L$. arcticus is known from the regulated Lake Inarijärvi in the municipality of Inari.

\section{Diversity of fish in the Lepidurus lakes}

As L. arcticus is an attractive prey for benthic fish, the diversity of fish species has been listed. Fish status is available from 379 of the 391 natural Lepidurus lakes. A total of ten fish species (Appendix 1) were documented (if a specific reference is not given in Appendix 1, 
we have used NIBC (Artsdatabanken) or own data). Given the fact that most records of $L$. arcticus originate from fish diet analysis, only a small number of ponds were considered free of fish $(\sim 3 \%)$. Most of the 379 natural lakes host brown trout (89\%), with many being introduced. Arctic char is also frequently occurring (>23\%), especially in the northern Scandes. The invasive Eurasian minnow Phoxinus phoxinus (L., 1758) has now spread to many of the Lepidurus lakes and have established in at least $9 \%$ of them. Grayling Thymallus thymallus (L., 1758), burbot Lota lota (L., 1758), perch Perca fluviatilis L., 1758, whitefish Coregonus lavaretus (L., 1758), ninespine stickleback Pungitius pungitius (L., 1758), northern pike Esox lucius L., 1758 and non-native American brook trout Salvelinus fontinalis (Mitchill, 1814) do also occur in some lakes. In addition, the regulated Lake Inarijärvi has three more species (salmon Salmo salar L. 1758, threespine stickleback Gasterosteus aculeatus L. and non-native lake trout Salvelinus namaycush (Walbaum, 1792)) and contained in total thirteen fish species.

\section{Interrelationship of lake air temperature and water temperature}

The frequency distribution of lake air temperature for the 391 Lepidurus lakes (Figure 5), shows an absolute range of about $5-12^{\circ} \mathrm{C}$, and an interquartile range of $7.1-8.5^{\circ} \mathrm{C}$, with mean and median values of 7.9 and $7.8^{\circ} \mathrm{C}$, respectively. Recent (2000-2019) summer temperatures (1 July - 15 September) were $0.91-1.52^{\circ} \mathrm{C}$ higher compared to the reference period 1961-1990 (Table 1).

The $8^{\circ} \mathrm{C}$ isotherm decreased from 1205 to $657 \mathrm{~m}$ a.s.l. from south $\left(\right.$ Møsstrond $59.83^{\circ} \mathrm{N}$ ) to north (Kilpisjärvi Kyläkeskus $69.05^{\circ} \mathrm{N}$ ), respectively.

The relationship between lake air temperature and water temperature reveal a nonlinear regression (Figure 6). Tested against real lake air temperatures, the deviation to the estimated values were minor in our reference lakes (cf. Stor-Innsjøen. Dragøyfjorden, Veivatnet, Buhovdvatnet and Øknevatn in southern Norway, cf. Appendix 2). When the lake air temperature exceeded $10^{\circ} \mathrm{C}$, the water temperature was $2-4^{\circ} \mathrm{C}$ higher than lake air temperature. In summers being warmer than $10^{\circ} \mathrm{C}$, the water temperatures becomes near $14^{\circ} \mathrm{C}$ in the Lepidurus lakes and only seldomly higher. For mountain lakes without $L$. arcticus, the water temperature may be higher. In our data matrix the highest water temperature in summer was $15.8^{\circ} \mathrm{C}$ in Lake Skurdalsvatnet (no L. arcticus) in 2018.

The water temperature measurements of the 32 lakes (of which 26 had $L$. arcticus) revealed that most of the lakes with lake air

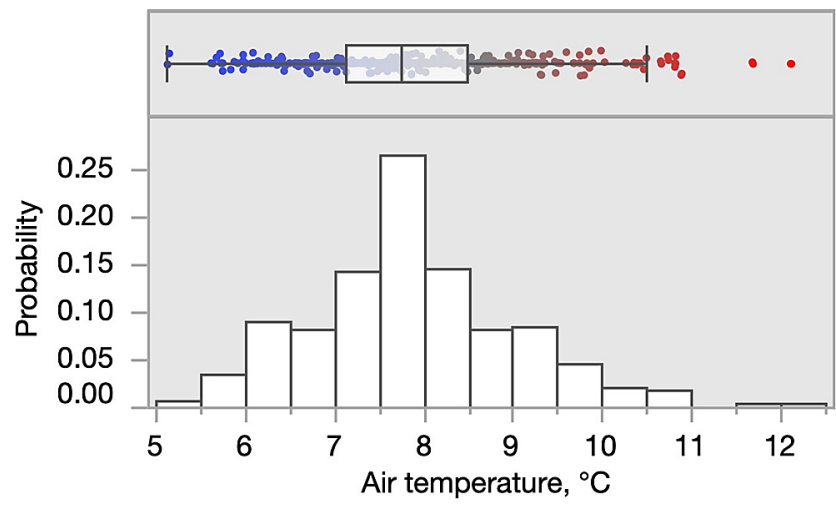

Figure 5. The distribution of average summer (1 July - 15 September) lake air temperature in 391 lakes with Lepidurus arcticus. The box-and-whiskers plot shows the interquartile range (IQR) as a box with the median as a vertical line, whereas the whiskers represent the 25 -percentile - $1.5 \mathrm{IQR}$ and 75-percentile + 1.5 IQR, respectively. Individual lake air temperatures are shown by a continuous colour scale (blue - gray -red) as in Figure 4.

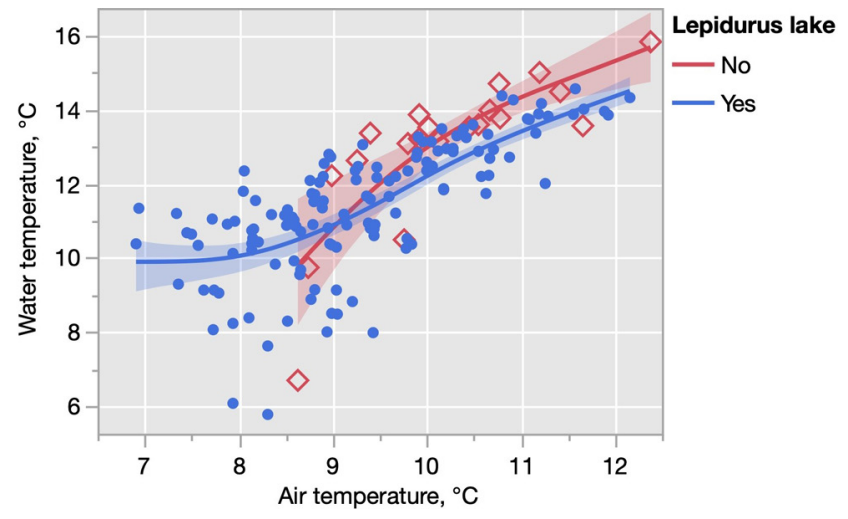

Figure 6. Relationship between average summer (1 July - 15 September) lake air temperature and water temperature in lakes with and without Lepidurus arcticus. Number of observations are as follows: for 26 Lepidurus lakes, $\mathrm{n}=133$; for 6 lakes without Lepidurus arcticus, $\mathrm{n}=20$. The curves are based on cubic splines with $95 \%$ confidence bands.

temperature warmer than $10^{\circ} \mathrm{C}$ had water temperatures $3-4^{\circ} \mathrm{C}$ above lake air temperature, i.e. $13-14^{\circ} \mathrm{C}$ (cf. Figure 6). Further, at a lower lake air temperature of approximately $8^{\circ} \mathrm{C}$, i.e. close to the median value of the 391 lakes in Figure 5, the corresponding water temperature for most of the lakes were within the range $8-12^{\circ} \mathrm{C}$. A more thorough statistical analysis (ANCOVA) on a smaller subset of five Lepidurus lakes with numerous data on lake air and water temperatures confirmed the water temperature in general to be significantly elevated compared to the lake air temperature, and that the relationship between lake air temperature and water temperature (the regression coefficients) differed between lakes (cf. text in Figure 7). The adjusted means of water temperatures were in the range of 9.6-12.2 ${ }^{\circ} \mathrm{C}$ at a lake air temperature of $9.2^{\circ} \mathrm{C}$ (geometric mean of the data). The graph of the regression curves for the individual lakes reveals a tendency for decreasing differences between water and lake air temperature at lower lake air temperatures for the coldest lakes (Figure 7).

In Lake Skurdalsvatnet where $L$. arcticus never has been recorded, the lake air temperature and water summer temperatures were 9.92$12.38^{\circ} \mathrm{C}$ and $13.9-15.8^{\circ} \mathrm{C}$ in 2017 and 2018 , respectively. The lake air temperatures during the cold summers in 1921-1923 and 1974

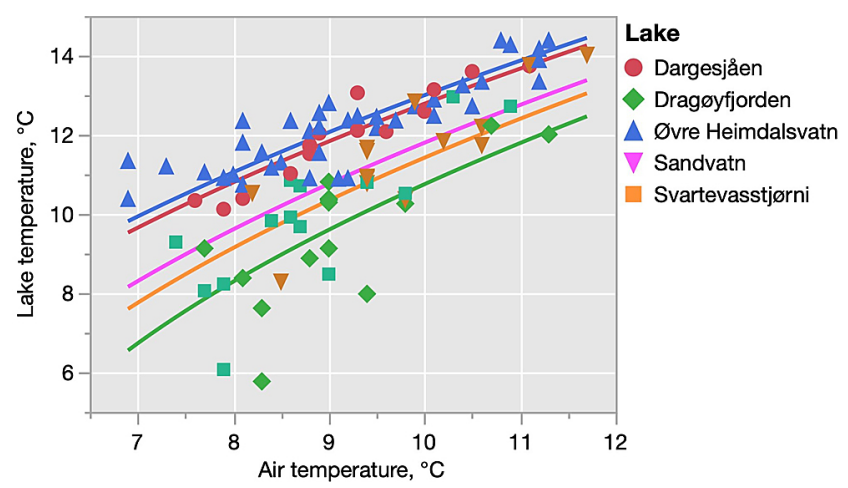

Figure 7. Regression curves for average summer (1 July - 15 September) water temperature as a function of lake air temperature for five lakes with Lepidurus arcticus. The curves are based on results from an analysis of covariance (ANCOVA) with water temperature as response variable and lake air temperature (log transformed), lake and their interactions as predictors: $\mathrm{n}=97, \mathrm{R}^{2}=0.79$; whole model test, $\mathrm{F}_{9,87}=36.69, \mathrm{p}<0.001$; test for effects: $\log$ temperature, $\mathrm{F}_{1,87}=147.45, \mathrm{p}<0.001$; lake, $\mathrm{F}_{4,87}=3.89$, $\mathrm{p}=0.006$; interactions, $\mathrm{F}_{4,87}=2.93, \mathrm{p}=0.025$. 


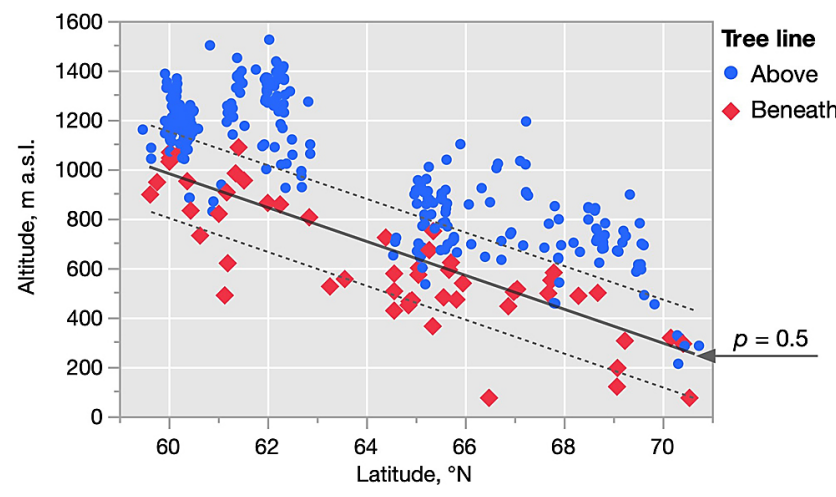

Figure 8. The occurrence of Lepidurus arcticus in relation to altitude and treeline of 391 natural Lepidurus lakes in the Scandes. Lakes marked as "Beneath" also include lakes on the treeline. The curve, based on a logistic regression, shows the 0.5 probability contour line (with $95 \%$ confidence band $): p($ beneath $)=\left(1+\mathrm{e}^{(-87.659+0.0171 \text {-Altitude }+1.180 \text { Latitude })}\right)^{-1}$, $\chi^{2}=173.4$, d.f. $=2, p<0.0001$; test for effects: altitude, $\chi^{2}=168.5, p<$ 0.0001 ; latitude, $\chi^{2}=91.4 \mathrm{p}<0.0001$. The treeline decreases from about $1000 \mathrm{~m}$ a.s.l. in the south to $200 \mathrm{~m}$ a.s.l. north to $70^{\circ} \mathrm{N}$.

were at the same level as in the cold summer of 2017. That summer the water temperatures were near $14^{\circ} \mathrm{C}$. This indicates that the water temperature in this lake tends to be regularly above $14^{\circ} \mathrm{C}$, even in cold summers.

\section{The treeline altitude at Lepidurus lakes}

Most of the 391 Lepidurus lakes are situated above the treeline (87\%). The treeline approximately follows the $9^{\circ} \mathrm{C}$ isotherm (1 July -15 September) which compares to a mean July normal of $10.1^{\circ} \mathrm{C}$ (cf. Table 1). The treeline decreases from 1050 to $350 \mathrm{~m}$ a.s.l. from 60 to $70^{\circ} \mathrm{N}$, respectively (Figure 8, Appendix 1).

\section{DISCUSSION}

Water temperature is a vital environmental factor both by acting directly on freshwater organisms but the cumulative effect throughout the life cycle may also be of primary concern. In this paper our main focus is to get an indication of the upper thermal threshold for $L$. arcticus, which simply means: "when is a lake too warm to host this crustacean?"

\section{The geographic distribution of Lepidurus lakes in the Scandes}

The central tendency regarding lake altitude of Lepidurus lakes is that they decrease from 1200 to $500 \mathrm{~m}$ a.s.l. along a south - north transect. Most lakes were distributed around the $8^{\circ} \mathrm{C}$ isotherm and a lake with lake air temperatures near to this isotherm holds water temperatures from 8 to $12^{\circ} \mathrm{C}$. Hence, a majority of the Lepidurus lakes have thermal conditions near to the species' highest metabolic rate at approximately $10^{\circ} \mathrm{C}$ (Lakka 2013) where the hatching rate is also most effective (Pasquali et al. 2019).

Most Lepidurus lakes are located at a lower lake air temperature than the $10^{\circ} \mathrm{C}$ isotherm and in warmer areas L. arcticus seems to be rare. The distribution appears to be dichotomous, with one northern and one southern "island". Only two Lepidurus lakes are known between 62.9 and $64.4^{\circ} \mathrm{N}$. In this particular region, the $10^{\circ} \mathrm{C}$ isotherm lies between 600 and $700 \mathrm{~m}$ a.s.l. As lakes in this part of the Scandes are mainly found at lower altitudes, we assume the majority to be too warm to host $L$. arcticus. In the northernmost part, e.g. north to $70^{\circ} \mathrm{N}$, the $10^{\circ} \mathrm{C}$ isotherm is found below $250 \mathrm{~m}$ a.s.l. The Lepidurus lakes in this area are all located close to this level. As only few lakes are situated higher than $300 \mathrm{~m}$ a.s.l. in this northern part of the Scandes, we assume that the potential of new findings is limited. Further north, on Bear Island and Spitsbergen, the species is mainly coastal (Sømme 1934; Røen 1962; Klemetsen 1985; Lakka 2013). In these northern islands, normal air temperature is less than $5^{\circ} \mathrm{C}$. Hence, summer temperature seems to be an important factor in orchestrating distribution.

Lepidurus arcticus is also regarded to be sensitive to fish predation, especially in the Arctic and the High Arctic (Jeppesen et al. 2001; Presthus Heggen et al. 2010). However, L. arcticus regularly coexists with fish in the Scandes where only 3\% of the Lepidurus lakes were fishless. In contrast to Spitsbergen and Bear Island, the Lepidurus lakes are relatively deep (70\% are deeper than $10 \mathrm{~m})$. This may provide the necessary refugia for an enhanced survival (Qvenild \& Hesthagen 2019).

\section{The upper thermal threshold for Lepidurus arcticus}

Few Lepidurus lakes have a lake air temperature higher than $11^{\circ} \mathrm{C}$ (cf. Figure 5). A lake which have lake air temperature at this level tends to have water temperature close to $14^{\circ} \mathrm{C}$ (cf. Figure 6). Water temperatures higher than this are scarcely noted in Lepidurus lakes in our study. Hence, we assume the upper thermal threshold for Lepidurus lakes to be close to the $14^{\circ} \mathrm{C}$ level. This result seen in the distribution pattern is also confirmed in the long-term study in Lake Skurdalsvatnet in the 1920s. Lake Skurdalsvatnet is situated at $782 \mathrm{~m}$ a.s.l. and is warmer than the lakes higher up on Hardangervidda. In this lake, L. arcticus was never recorded even though all the upstream lakes hold viable populations of the species (Dahl 1917, 1926, 1932; Amundsen 1976). Even in cold periods, Lake Skurdalsvatnet seemed to have water temperatures of approximately $14^{\circ} \mathrm{C}$, i.e. near the upper thermal threshold. With drifting of L. arcticus from the lakes upstream, the species would have established as it quickly did in the impounded Lake Pålsbufjorden further downstream, when offered a colder environment (Dahl 1932).

A regional climatic forcing will not necessarily induce a common water temperature response, due to the influence of catchment properties on the water temperature regime (Kvambekk \& Melvold 2010). This implies later ice break-up and colder water in catchments with heavy snow deposits (Raddum \& Fjellheim 2002; Christoffersen et al. 2008; Borgstrøm 2016; Qvenild \& Hesthagen 2019). We assume that this is the main reason why some of the Lepidurus lakes are located at rather low altitudes, i.e. the westernmost lakes on Vikafjellet in Vestland county and Lake Rundvatn in Nordland county, both locations with winter precipitation more than 1600 $\mathrm{mm}$. In such lakes, the water temperature may be near the lake air temperature or even below after winters with heavy snow falls. The same result was also noted in lakes with a strong oceanic component on the western part of Hardangervidda. This is reflected in a wider range of water temperatures at low lake air temperatures as revealed in the nonlinear relationship in Figure 6.

\section{Early life survival}

Branchiopod crustaceans rely on banks of resting eggs to bridge periods of drought or frost and to buffer against the effects of environmental variability (Brendonck 1996). This is evident from the fact that only a fraction of the eggs normally hatches (Hann \& Lonsberry 1991; Pasquali et al. 2019).

Adult $L$. arcticus seem to tolerate rather high temperatures, but the juvenile phase may be more susceptible to abrupt temperature changes that may result in lethal physiological injuries (Pasquali et 
al. 2019). Also, the moult has proved to be a vulnerable stage (Thiéry 1997). In Lake Solvatnet at Spitsbergen, no hatching of L. arcticus was observed at 15 and $25^{\circ} \mathrm{C}$ in the laboratory, and it was assumed that such conditions exceeded the physiological tolerance of the eggs (Pasquali et al. 2019). In natural lakes, abrupt changes in water temperature in the initial phase following ice break-up, may frequently occur. In Lake Øvre Heimdalsvatn in 2018, the water temperature increased from 4 to $14^{\circ} \mathrm{C}$ in only 10 days (Hydra II, nve.no). In small and shallow lakes and ponds such temperature shocks are even more likely to occur.

The hatching phase and the pelagic larval phase has also proved to be vulnerable to acid water. During the spring with heavy snow melt at ice break-up, a drop in $\mathrm{pH}$ is frequently measured (Fjellheim et al. 2002). This may be harmful or fatal to the larvae (Borgstrøm \& Hendrey 1976). Hence, we assume that the juvenile phase of $L$. arcticus to be critical in terms of evaluating risks of extinction.

\section{Life cycle mismatches}

As in almost all Brachiopoda, L. arcticus has both dormant and subitaneous embryos (Borgstrøm \& Larsson 1974; Fryer 1988; Lakka, unpubl.). Newly hatched eggs deposited in water reveal a need for a certain amount of degree days to hatch. Eggs from adult L. arcticus sampled in August and incubated at 4 to $5^{\circ} \mathrm{C}$, hatched in February (Borgstrøm \& Larsson 1974). A recent experiment with eggs from a natural Finnish lake in August which were incubated at a water temperature of 1 to $3^{\circ} \mathrm{C}$, hatched in June (Lakka, unpubl.). Even though these results were achieved in the laboratory, it indicates a cumulative need of thermal energy to fulfil the embryonic development. This is in line with general embryonic development for a variety of different taxa (Gillooly \& Dodson 2000). We assume that the results achieved by Lakka reflects the real environmental condition met by the $L$. arcticus eggs in the dormant phase through winter.

Since eggs remain viable for years when dry or frozen, it is assumed that development of the embryos is arrested. The small and shallow Lake Solvatnet at Spitsbergen freezes solid in winter, the eggs freeze, and development of the embryos are arrested (Pasquali et al. 2019). Eggs picked after ice-break up and incubated at 5 and $10^{\circ} \mathrm{C}$ start to hatch after 15 and 7 days, respectively. Hence, eggs incubated at $5^{\circ} \mathrm{C}$ in Solvatnet needed much shorter time to hatch than the eggs incubated at 4 to $5^{\circ} \mathrm{C}$ from the lake studied by Borgstrøm \& Larsson (1974) and Lakka (unpubl.). Thus, some of the development in the embryonic phase must have occurred in the previous summer or earlier. This emphasizes the significance of the egg bank as a buffer to variable environmental conditions (Hann \& Lonsberry 1991; Brendonck 1996). In natural lakes in the Scandes, the resting eggs are deposited in the littoral zone, normally with water temperature between 1 and $2^{\circ} \mathrm{C}$ in winter. Thus, the embryos will develop continuously during winter. As the eggs are laid in August September, their thermal path through dormancy may take different ways depending on water temperature, to hatching in June - July. A warm summer usually results in a high thermal load on a yearly basis (Kvambekk \& Melvold 2010). With a too high cumulation of thermal energy during the first period of the embryonic phase, life cycle mismatches may be the consequence. If the required thermal input to fulfil the embryonic phase are achieved by elevated temperatures in autumn/ winter, the eggs may hatch under complete dark conditions in winter. We assume this mismatch between environmental conditions and life-cycle events to be the main reason for the absence of $L$. arcticus in warm lowland lakes in the Scandes.

\section{Lepidurus arcticus populations at threat}

Whereas L. arcticus seems to be common in Norway, it has been red listed as near-threatened (NT) in Sweden and endangered (EN) in Finland. Given its Arctic origin and its susceptibility to acid precipitation and predation pressure from co-existing fish populations, we assume that many populations have gone extinct in the Scandes.

Historically, a range retraction is evident by the fact that $L$. arcticus had a much wider distribution according to fossil records from different parts of Europe (Økland \& Økland 2003). From Norway, fossil remnants of $L$. arcticus were found in the Brøndmyra bog $\left(59.4825^{\circ} \mathrm{N}, 7.5211^{\circ} \mathrm{E}\right) 14 \mathrm{~m}$ a.s.l. (Arne Fjellberg, pers. comm.). This locality is located $131 \mathrm{~km}$ southwest of the southernmost record of L. arcticus, in Lake Nørdre Gjuvvatn in southern outskirt of the Scandes.

As shown in this study, the distribution of L. arcticus mainly follows the alpine zone. There are some exceptions where it occurs in the lower subalpine birch zone. In total, $87 \%$ of the studied lakes are situated above the treeline. The present treeline in the Scandes is formed by birch, and it is assumed to mainly be a response of climatic conditions (Dahl \& Nesje 1996; Odland 1996). The treeline at the Lepidurus lakes in this study closely follows the summer isotherm near $9^{\circ} \mathrm{C}$ which agrees with that stated for birch (Odland 1996). The warm period in early-Holocene (7800-7600 BP) may be regarded as an early analogue for possible increased precipitation as a result of continued greenhouse warming (Dahl \& Nesje 1996). Both pine (Pinus sylvestris) and birch then extended their distribution to altitudes far above the present treeline (Moe 1979; Aas \& Faarlund 1988; Dahl \& Nesje 1996). In the first two decades of the 2000s, the mean summer temperature has risen to a level above $1{ }^{\circ} \mathrm{C}$ compared to the normal period (cf. Table 1) and a further increase is projected (Hanssen-Bauer et al. 2017). This compares to a significant raise in the treeline which may reach levels seen in the early- to mid-Holocene. Thus, in the early- to mid-Holocene, the range retractions of $L$. arcticus may have been massive if it followed the treeline extension. We assume that a later recolonization in colder lakes formed the present occurrences in the Scandes. Hence, we assume the treeline to be an indicator of a possible range retraction of L. arcticus populations from the lower part of its distribution area.

The aquatic environment is rapidly changing in the Scandes and continuous monitoring programs are needed. The only long-term program in the Scandes with repeated monitoring of environmental conditions and biota is Lake Øvre Heimdalsvatn (Brittain et al. 2019). In this lake situated at the present treeline, L. arcticus has practically been absent from brown trout diet since 1993 (Brittain et al. 2019). Predation from brown trout and Eurasian minnow is obviously of prime concern for the occurrence of L. arcticus in this lake, but an additive stressor is likely to be the significant warming seen after 2000. Thus, a further warming may be detrimental to the L. arcticus population in the lake. Here, and in the many Lepidurus lakes with more than ten-year-old observations, updated surveys would be highly rewarding and possibly disclose extinct populations in some lakes. The cold adapted L. arcticus may be a good indicator species to changing environmental conditions (Lakka 2013, 2020).

\section{CONCLUSIONS}

Lepidurus arcticus is recorded in 479 locations in the Scandes, making this southern outreach to be a significant part of the species' total distribution area. The central tendency in the distribution regarding 
lake altitude is that it decreases from about 1200 to $500 \mathrm{~m}$ a.s.l. along a south-north transect. Most of the lakes were distributed around the $8^{\circ} \mathrm{C}$ isotherm, indicating water temperatures from 8 to $12^{\circ} \mathrm{C}$. This is near to the species' highest metabolic rate at approximately $10^{\circ} \mathrm{C}$ where the egg hatching rate is also most effective. The majority of Lepidurus lakes are located at a lower lake air temperature than the $11^{\circ} \mathrm{C}$ isotherm which is equivalent to a water temperature near $14^{\circ} \mathrm{C}$. In warmer lakes, L. arcticus seems to be rare and water temperatures above $14^{\circ} \mathrm{C}$ may be regarded as critical. Lice cycle mismatches seem to be the main reason in lakes warmer than this. The juvenile stage also seem to be very sensitive to abrupt changes in water temperature.

In total, $87 \%$ of the studied lakes are situated above the treeline which closely follows the summer isotherm near to $9^{\circ} \mathrm{C}$. The treeline has proved to give a direct response to altered climate conditions and thus, the treeline may be an indicator of a possible range retraction of $L$. arcticus populations in the lower part of its distribution area. An increase of more than $1^{\circ} \mathrm{C}$ is already experienced in the first two decades of the 2000s. The widespread trend of warming lakes is anticipated to continue unabated and does not augur well for the fate of cold-water adapted species. Far more water temperature monitoring locations should be established to get a better prediction of freshwater ecosystems effects of global warming. Lepidurus arcticus may be a good indicator species of arctic and alpine aquatic communities, and a continuous monitoring program following Lepidurus lakes near to and below the treeline, would be highly rewarding. The upper thermal threshold of approximately $14^{\circ} \mathrm{C}$ may be used to evaluate Lepidurus lakes at threat.

\section{ACKNOWLEDGEMENTS}

The authors gratefully acknowledge Roar Kjær for drawing the maps and Jon Museth and Sven E. Gabrielsen for substantial support with the temperature loggers. A special thank is given to Åsmund Tysse and Anund S. Kvambekk for valuable support with data acquisition. We want to thank Venla Kontiokari, Anni-Mari Pulkkinen, Ari Savikko, Antti Eloranta, Katariina Hynninen, Lauri Lahtasela, Maija Sujala, Ole Nashoug, Herman Stakseng, Gunnar Elnan, Georg Gjøstein, Ove Gåsdal, Stein Lier-Hansen, Halvor Nordjordet, Jarle Nordjordet, Per-Jan Sandven, Ivar Sygnabere and Stein P. Haakanes for valuable assistance in the field. Lastly, we are most grateful to John E. Glynn for a linguistic check on the draft-manuscript.

\section{REFERENCES}

Aas B, Faarlund T. 1988. Postglacial forest limits in central south Norwegian mountains. Radiocarbon datings of subfossil pine and birch specimens. Norsk geografisk tidsskrift 42: 25-61. (In Norwegian with an English summary).

Aass P. 1969. Crustacea, especially Lepidurus arcticus Pallas, as brown trout food in Norwegian mountain reservoirs. Report, Inst. Freshw. Res., Drottningholm, 49: 183-201.

Amundsen T. 1976. Fiskeribiologiske undersøkelser for Dagalivassdraget 1974-75. Fiskerikonsulenten for Øst-Norge. Rapport Na IV-3.2. 285 pp. (In Norwegian).

Arnold GP. 1966. Observations on Lepidurus arcticus (Pallas) (Crustacea, Notostraca) in east Greenland. Annals and Magazine of Natural History 9: 599-617.

Blomkvist D. 1995. Bladfotingar som försurningsindikatorer i fjällen. Länsstyrelsen i Norrbottens län. Rapport nr. 3-1995. 30 pp. (In Swedish).
Borgstrøm R, Hendrey GR. 1976. pH tolerance of the first larval stages of L. arcticus (Pallas) and adult Gammarus lacustris G.O.Sars. SNSFprosjektet, Oslo-Ås, Norway. IR 22/76. 37 pp. (In Norwegian with an English summary).

Borgstrøm R, Larsson P. 1974. The first three instars of Lepidurus arcticus (Pallas) (Crustacea: Notostraca). Norw. J. Zool. 22: 45-52.

Borgstrøm R. 2016. Auren på Hardangervidda er sterkt påverka av klimatilhøve. Naturen nr. 4-2016: 147-155. (In Norwegian).

Borgstrøm R. 2019. Skjoldkreps - eit viktig næringsdyr i høgfjellsvatn som er sterkt påverka av miljøfaktorar. VANN 01-2019: 33-42. (In Norwegian with an English summary).

Bottrell HH. 1975. Generation time, length of life, instar duration and frequency of moulting, and their relationship to temperature in eight species of cladocera from the River Thames, Reading. Oecologia 19: 129-140.

Brendonck L. 1996. Diapause, quiescence, hatching requirements: What we can learn from large freshwater branchiopods (Crustacea: Branchiopoda: Anostraca, Notostraca, Conchostraca). Hydrobiologia 320: 85-97.

Brendonck L, Rogers DC, Olesen J, Weeks S, Hoeh WR. 2008. Global diversity of large branchiopods (Crustacea: Branchiopoda) in freshwater. Hydrobiologia 595: 167-176. doi: 10.1007/s10750-0079119-9.

Brittain JE, Borgstrøm R. 2010. The Norwegian reference lake ecosystem, Øvre Heimdalsvatn. Hydrobiologia 642: 5-12. doi: 10.1007/s10750010-0154-6.

Brittain JE, Borgstrøm R, Bremnes T, Haaland S, Mjelde M, Nilssen JP, Skjelbred B. 2019. Øvre Heimdalsvatn - økologisk langtidsovervåking. Naturhistorisk museum, Universitetet i Oslo, Rapport nr. 84.64 pp. (In Norwegian with an English summary).

Christoffersen KS, Amsinck SL, Landkildehus F, Lauridsen TL, Jeppesen E. 2008. Lake flora and fauna in relation to ice-melt, water temperature and chemistry at Zackenberg. Advances in Ecological Research Vol. 40: 371-389.

Dahl K. 1917. Ørret og ørretvann. Studier og forsøk (new edition in 1943). J.W.Cappelens forlag. 182 pp. (In Norwegian).

Dahl K. 1926. Undersøkelser ved Tunhøvdfjorden angaaende fiskens næringsforhold før og efter reguleringen. Meddelelser fra Norges Vassdrags- og Elektrisitetsvesen. Foss 1.18 pp. (In Norwegian).

Dahl K. 1932. Influence of water storage of food conditions on trout in Lake Paalsbufjord. Skrifter utgitt av Det Norske Videnskaps-Akademi i Oslo. I. Mat.-Naturv. Klasse. 1931. No. 4. 53 pp.

Dahl SO, Nesje A. 1996. A new approach to calculating Holocene winter precipitation by combining glacier equilibrium-line altitudes and pine-tree limits: a case study from Hardangerjøkulen, central southern Norway. The Holocene 6, 4: 381-398.

Donald DB. 1983. Erratic occurrence of anostracans in a temporary pond: colonization and extinction or adaption to variation in annual weather? Can. J. Zool. 61: 1492-1498.

Fjellheim A, Tysse Å, Bjerknes V, Wright RF. 2002. Finprikkauren på Hardangervidda. DN-utredning 2002-1. 58 pp. (In Norwegian).

Fjellheim A, Tysse $\AA$, Bjerknes W. 2007. Fish Stomachs as a Biomonitoring Tool in Studies of Invertebrate Recovery. Water, Air and Soil Pollution 7: 293-300. doi: 10.1007/s11267-006-9074-x.

Fryer G. 1988. Studies on the functional morphology and biology of the Notostraca (Crustacea: Branchiopoda). Philosophical Transactions of the Royal Society B. Vol. 321: 27-124. doi: 10.1098/rstb.1988.0091.

Gillooly JF, Dodson SI. 2000. The relationship of neonate mass and incubation temperature to embryonic development in a range of animal taxa. Journal of Zoology 251: 369-375.

Hammar J. 2002. The Subarctic Cap of Europe - the Fennoscandian Alpine, Tundra and Taiga Ecoregion. A reconnaissance study and biodiversity vision for a WWF Global 200 initiative in Norway, Sweden, Finland and Russia. Report, WWF International Arctic Program, Oslo. 139 pp. 
Hann BJ, Lonsberry B. 1991. Influence of temperature on hatching of eggs of Lepidurus couesii (Crustacea, Notostraca). Hydrobiologia, 212: 61-66. doi: 10.1007/BF00025987.

Hanssen-Bauer I, Førland EJ, Haddeland I, Hisdal H, Lawrence D, Mayer S, Nesje A, Nilsen JEØ, Sandven S, Sandø AB, Sorteberg A, Ådlandsvik B. 2017. Climate in Norway 2100 - a knowledge base for climate adaption. The Norwegian Center for Climate Services (NCCS). Report no. 1/2017. 45pp.

Hessen D, Rueness EK, Stabell M. 2004. Circumpolar analysis of morphological and genetic diversity in the Notostracan Lepidurus arcticus. Hydrobiologia 519: 73-84.

Järvinen A, Lakka H-K, Sujala M. 2014. The Arctic tadpole shrimp, a living fossil in mountain waters, again found in Finland. Nature Scientist 1-2014:19-24. (In Finnish).

Jeppesen E, Christoffersen K, Landkildehus F, Lauridsen T, Amsinck SL, Riget F, Søndergaard M. 2001. Fish and crustaceans in northeast Greenland lakes with special emphasis on interactions between Arctic char (Salvelinus alpinus), Lepidurus arcticus and benthic chydorids. Hydrobiologia 442: 329-337.

Klausen TR. 2012. Population regulation in the tadpole shrimp Lepidurus arcticus. MSc-thesis, Norwegian University of Science and Technology, Department of Biology. $25 \mathrm{pp}$.

Klemetsen A, Grotnes PE, Holthe H, Kristoffersen K. 1985. Bear Island Charr. Report, Inst. Freshw. Res., Drottningholm, 62: 98-119.

Koli L. 1957. Beiträge zur Kenntnis der Euphyllopodenfauna Finnlands. Archiv Societatis Zoologicae Botanicae Fennica 'Vanamo'. 11, 2 (Helsinki): 108-111.

Kvambekk AS, Melvold K. 2010. Long-term trends in water temperature and ice cover in the subalpine lake, Øvre Heimdalsvatn, and nearby lakes and rivers. Hydrobiologia (2010) 642: 47-60. doi: 10.1007/s10750 010-0158-2.

Lakka H-K. 2013. The ecology of a freshwater crustacean: Lepidurus arcticus (Branchiopoda, Notostraca) in a high Arctic region. The University Centre in Svalbard, Department of High Arctic Biology. MS Thesis. $151 \mathrm{pp}$.

Lakka H-K, Leppänen A, Mykrä H, Vaajala M, Raineva S, Lensu T, Salonen E. 2019. Arctic tadpole shrimp as whitefish food in Lake Inarijärvi. Luonnon Tutkija 2: 66-70. (In Finnish).

Lakka H-K. 2020. Environmental Changes in Arctic Freshwaters. The Response of Indicator Species to Global Warming and Acidification in the Arctic. PhD-Thesis, University of Jyväskylä, 2020: 51 pp.

Laaksonen K. 1976. The dependence of mean air temperatures upon latitude and altitude in Fennoscandia (1921-1950). Ann. Acad. Sci Fenn. A III 119: 1-18.

Lindholm M, Stordal F, Hessen DO, Moe SJ, Aass P. 2012. Climate driven range retraction of an Arctic freshwater crustacean. Freshwater Biology 57: 2591-2601. doi: 10.1111/fwb.12030.

Lindholm M, Hessen DO, Færøvig PJ, Rognerud B, Andersen T, Stordal F. 2015. Is distribution of cold stenotherms constrained by temperature? The case of the Arctic fairy shrimp (Branchinecta palludosa O.F.Müller 1788). Journal of Thermal Biology 53: 46-52. doi: 10.1016/j.jtherbio.2015.08.005.

Lingdell P-E, Engblom E. 2002. Bottendjur som indikator på kalkningseffekter. Rapport 5235, Naturvårdsverket, Stockholm. 191 pp. (In Swedish).

Livingstone DM, Lotter AF, Walkery IR. 1999. The Decrease in Summer Surface Water Temperature with Altitude in Swiss Alpine Lakes: A Comparison with Air Temperature Lapse Rates. Arctic, Antarctic, and Alpine Research, 31 (4): 341-352. doi: 10.1080/15230430.1999.12003319. Longhurst AR. 1955. Evolution in the notostraca. Evolution 9: 84-86.

Moe D. 1979. Tregrense-fluktuasjoner på Hardangervidda etter siste istid. I: Nydal R, Westin S, Hafsten U, Gulliksen S. (eds): Fortiden i søkelyset. ${ }^{14} \mathrm{C}$ datering gjennom 25 år. Laboratoriet for radiologisk datering, Trondheim: 199-208. (In Norwegian).

Neretina AN, Gololobova MA, Neplyukhina AA, Zharov AA, Rogers CD, Horne DJ, Protopopov AV, Kotov AA. 2020. Crustacean remains from the Yuka mammoth raise questions about non-analogue freshwater communities in the Beringian region during the Pleistocene. Sci Rep 10, 859 (2020). doi: 10.1038/s41598-020-57604-8.

Odland A. 1996. Differences in the vertical distribution pattern of Betula pubescens in Norway and its ecological significance. Paläoklimaforschung 20: 43-59.

Presthus Heggen M, Birks HH, Anderson NJ. 2010. Long-term ecosystem dynamics of a small lake and its catchment in west Greenland. The Holocene 20(8): 1207-1222. doi: 10.1177:0959683610371995.

Pasquali V, Calizza E, Setini A, Hazzlerigg D, Christoffersen KS. 2019. Prelimenary observations on the effect of light and temperature on the hatching success and rate of Lepidurus arcticus eggs. Ethology Ecology \& Evolution 31(4): 348-357. doi: 10.1080/03949370.2019.1609093.

Qvenild T, Rognerud S. 2018. Ørreten på Hardangervidda. Klimaets betydning for årsklassestyrke og produksjon av fisk og næringsdyr $\mathrm{i}$ Sandvatn 2001-2017. Norwegian Institute for Water Research (NIVA), Report L.NR. 7267-2018. 34 pp. (In Norwegian with an English summary).

Qvenild T, Fjeld E, Fjellheim A, Rognerud S, Tysse Å. 2018. Climatic effects on a cold stenotherm species Lepidurus arcticus (Branchiopoda, Notostraca) on the southern outreach of its distribution range. Fauna norvegica 38: 37-53. doi: 10.5324/fn.v38i0.2598.

Qvenild T, Hesthagen T. 2019. Environmental conditions limit the distribution of Lepidurus arcticus (Branchiopoda; Notostraca) on the Hardangervidda mountain plateau, Southern Norway. Fauna norvegica 39: 77-110. doi: 10.5324/fn.v39i0.2687.

Raddum GG, Fjellheim A. 2002. Species composition of freshwater invertebrates in relation to chemical and physical factors in high mountains in southwestern Norway. Water, Air \& Soil Pollution, Focus 2: $311-328$

Rogers DC. 2001. Revision of the nearctic Lepidurus (NOTOSTRACA). Journal of Crustacean Biology, 21(4): 991-1006. doi: 10.1651/0278-0372(2001)021\%5b0991:ROTNLN\%5d2.0.CO;2.

Røen UI. 1962. Studies on Freshwater Entomostraca in Greenland. II. Locations, Ecology and Geographical Distribution of the Species. Meddelser om Grønland Bd. 170, No. 2. 149 pp.

Sømme S. 1934. Contributions to the biology of Norwegian fish food animals. I. Lepidurus arcticus Pallas. Avh. Norske Vidensk Akad 6: $1-36$.

Thiéry A. 1997. Horizontal distribution and abundance of cysts of several large branchiopods in temporary pool and ditch sediments. Hydrobiologia, 259: 177-189. doi: 10.1023/A:1003124617897.

Økland KA, Økland J. 2003. Skjoldkrepsen Lepidurus arcticus i Norge. Fauna nr. 1-2003: 2-12. (In Norwegian with an English summary).

Editorial responsibility: Anne Helene Tandberg.

This article is open-access and distributed under the terms of the Creative Commons Attribution 4.0 International license. This permits all noncommercial use, distribution, and reproduction in any medium, provided the original work is properly cited.

(http://creativecommons.org/licenses/by/4.0/). 


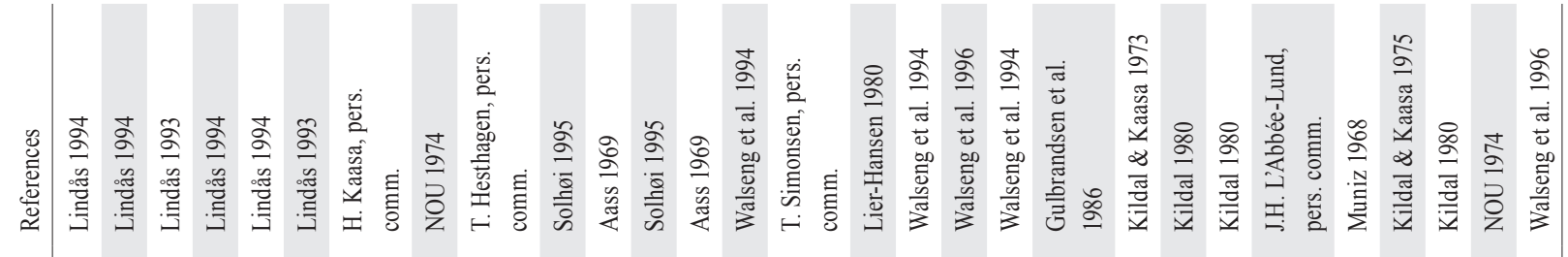

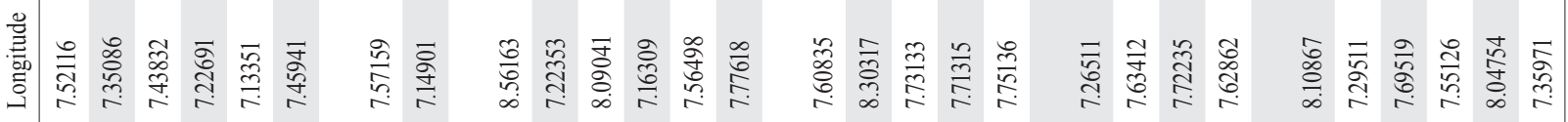

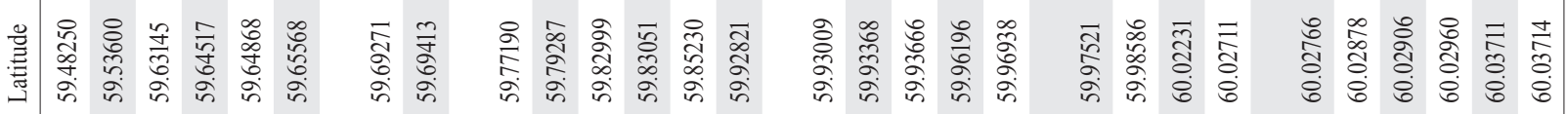

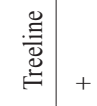

㐘

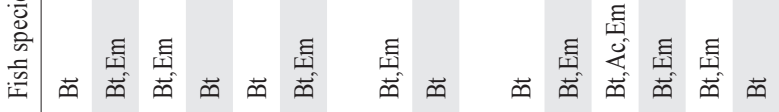

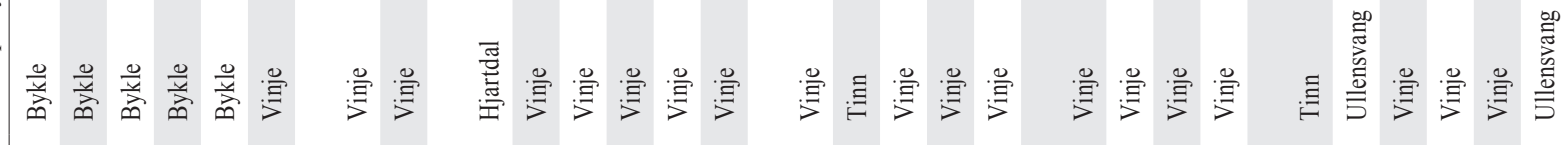

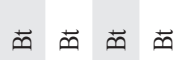

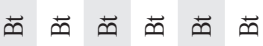
$\stackrel{2}{=}$

ำ

$\stackrel{n}{\infty}$ $\stackrel{+}{-}$ $\dot{g}$

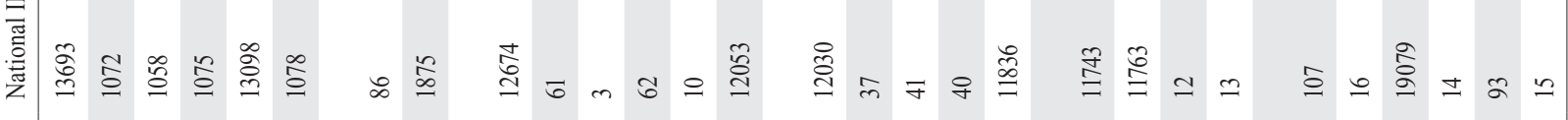

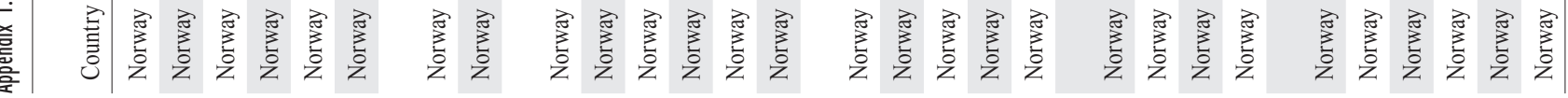




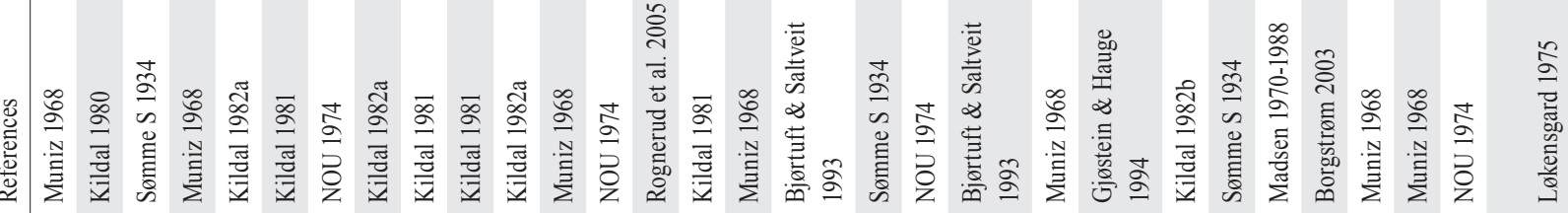

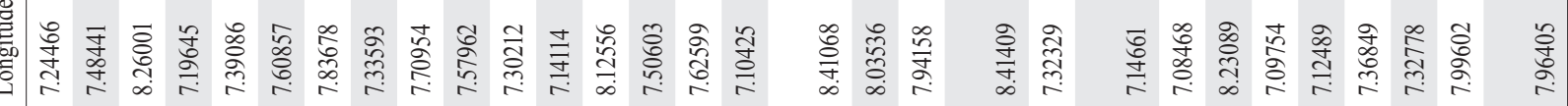

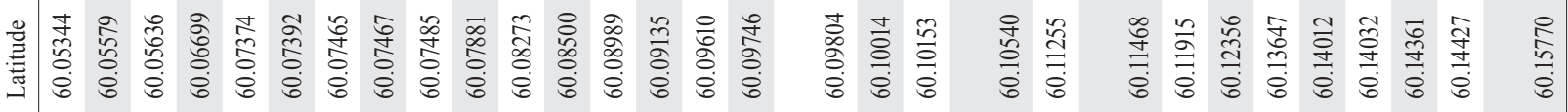
恚

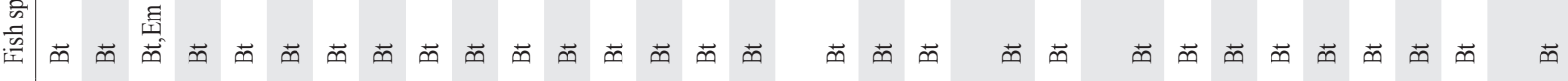

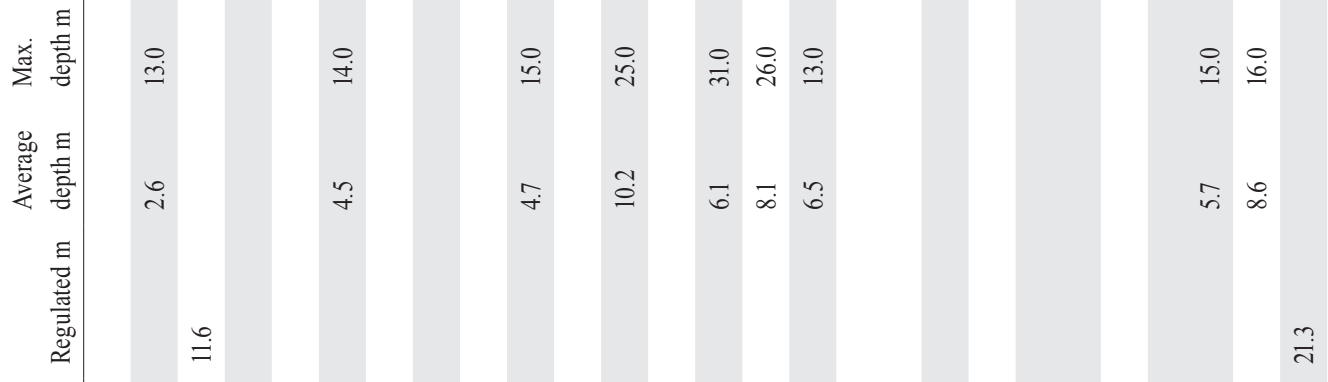

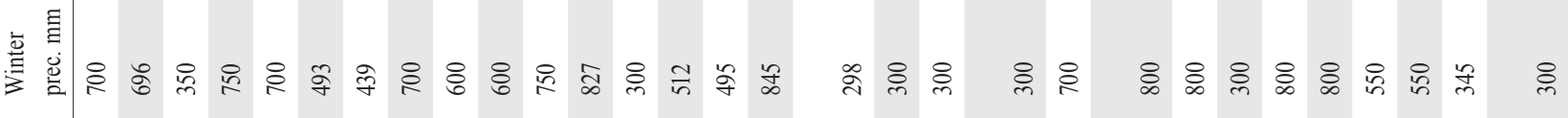

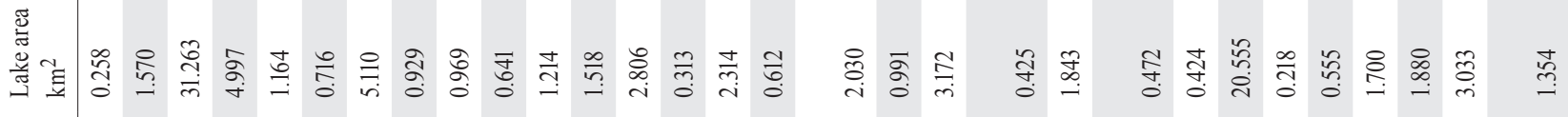

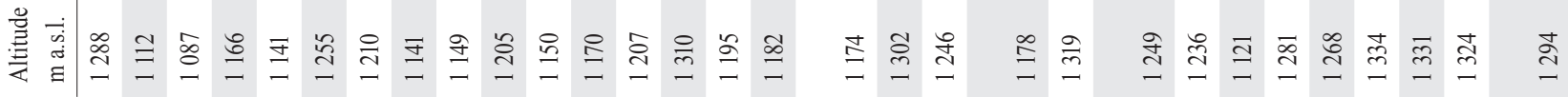

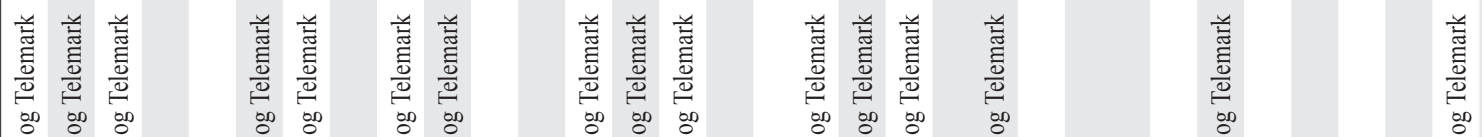

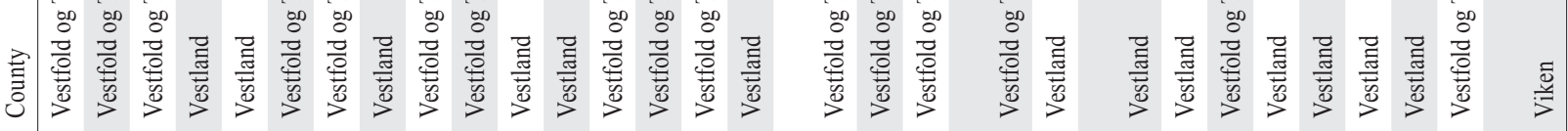

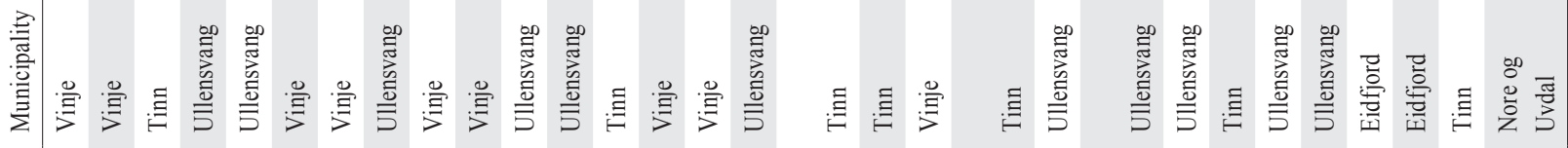

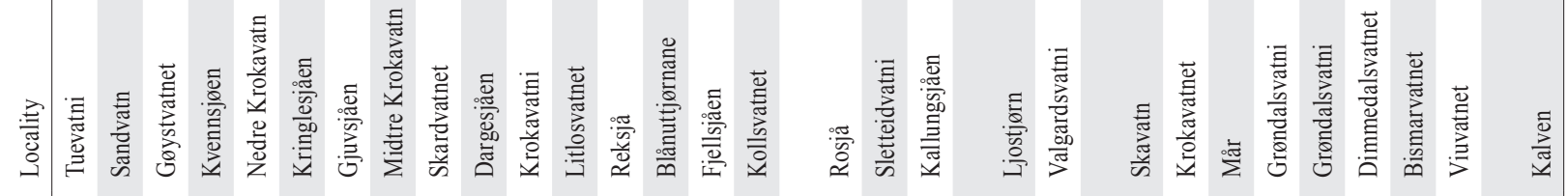
$\dot{\circ}$ 常 产芯芯

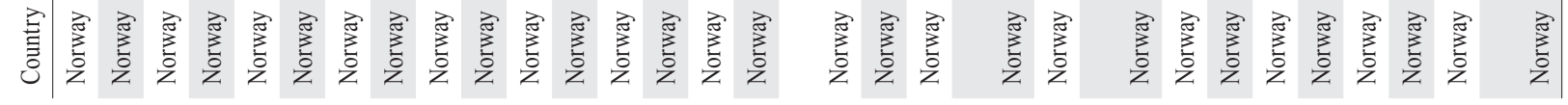




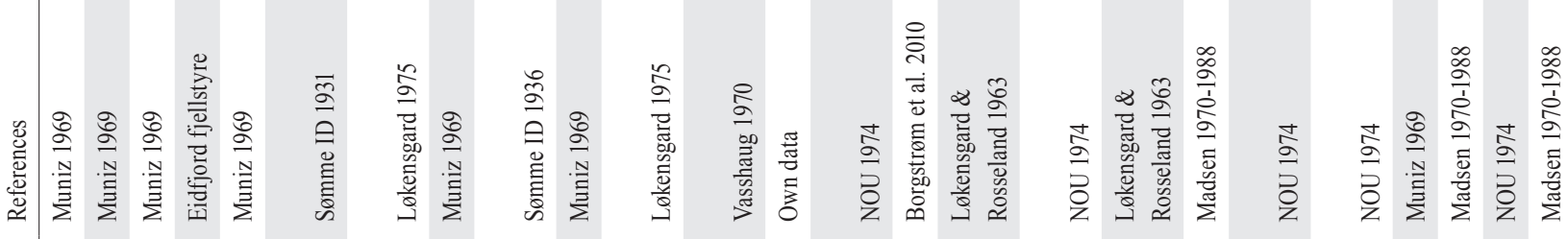

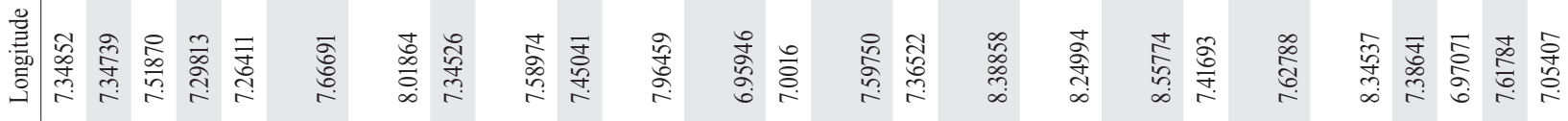

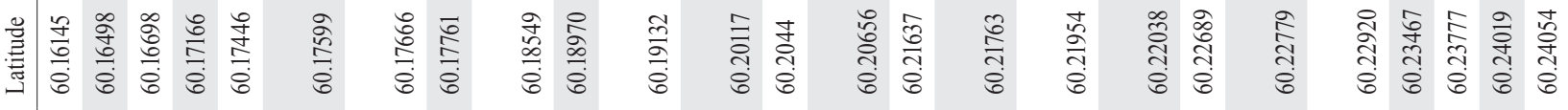

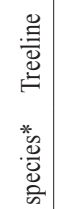

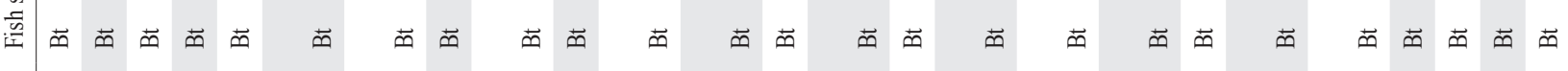
总

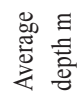

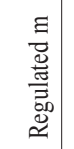

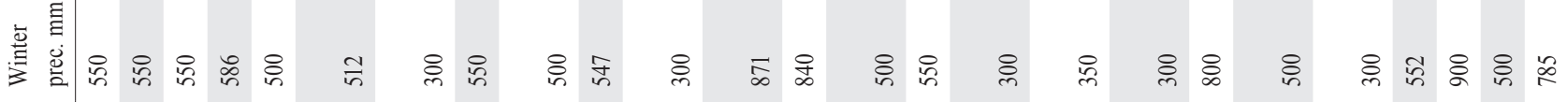

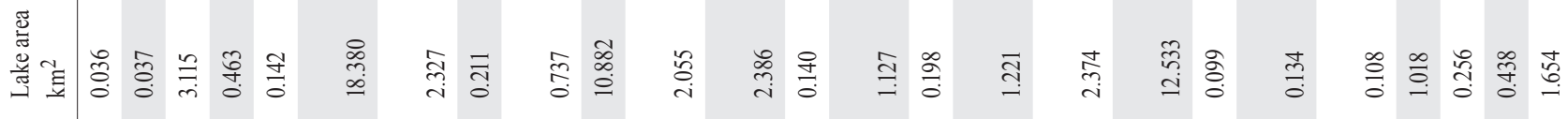

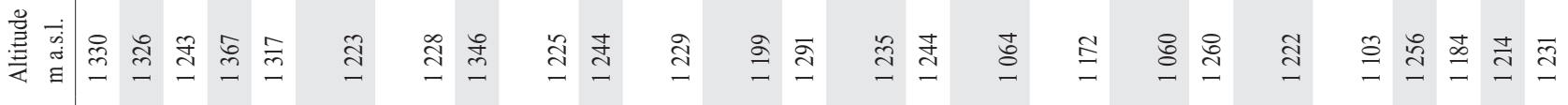

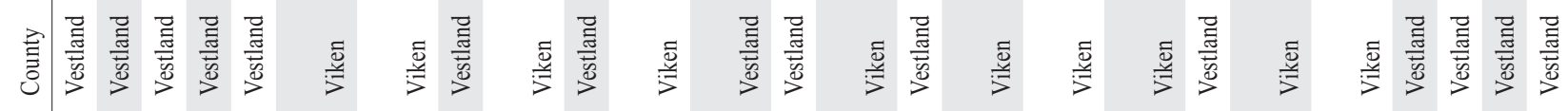

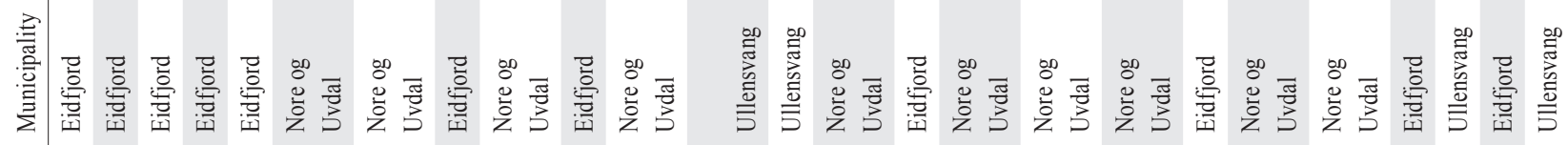

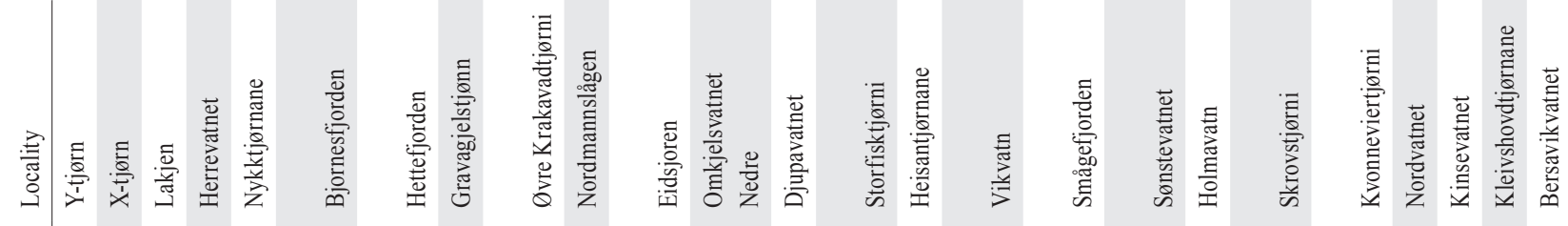
$\dot{\dot{g}}$

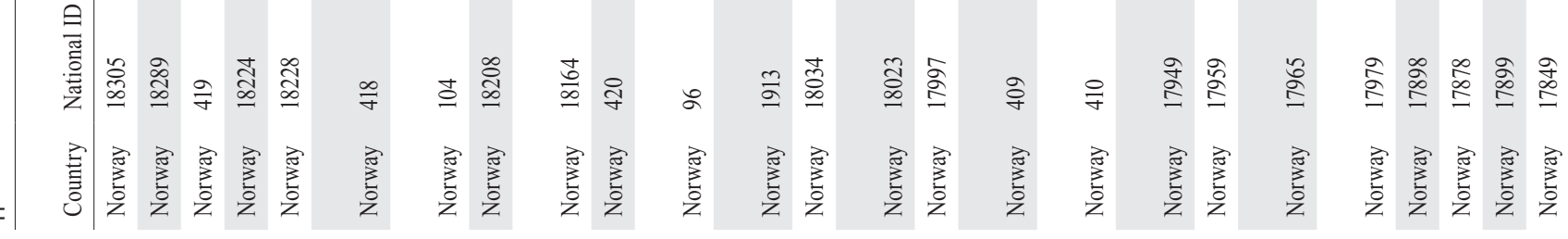




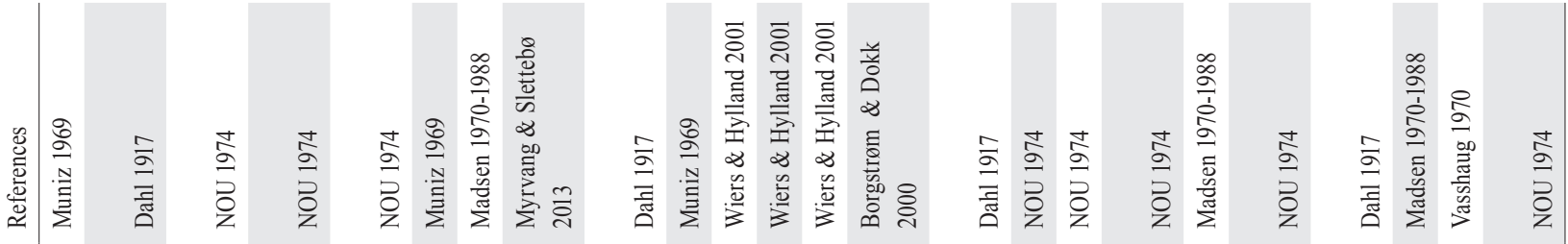

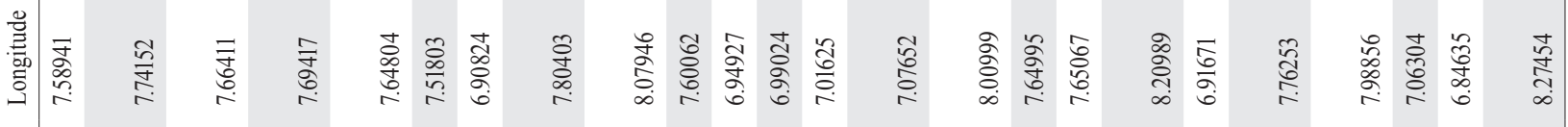

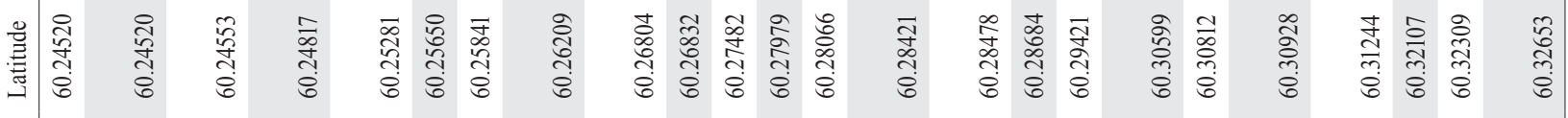

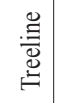

葛.

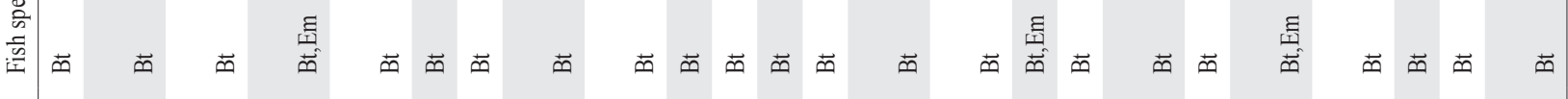

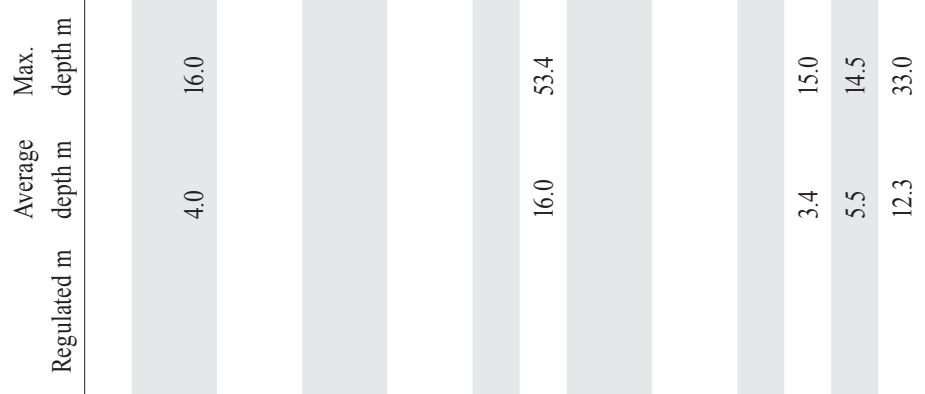

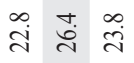

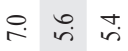
$\ddot{m}$

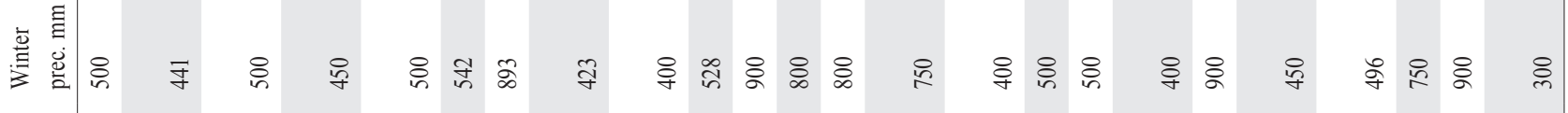

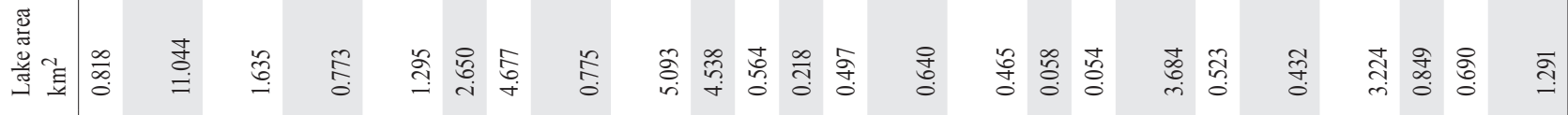

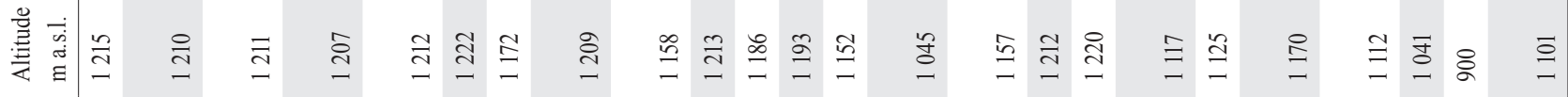

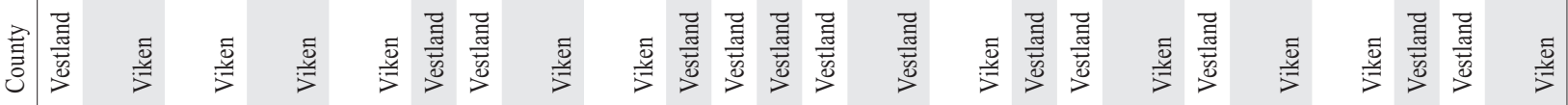

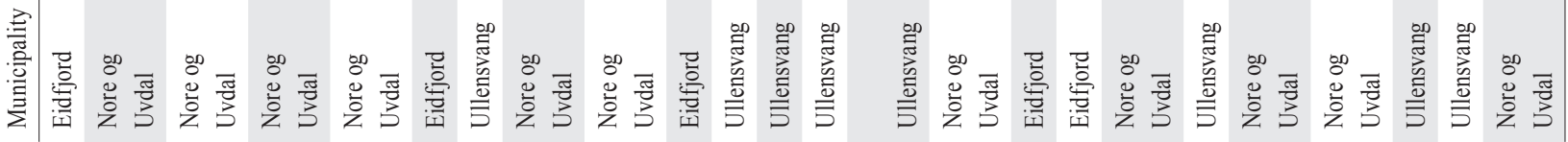

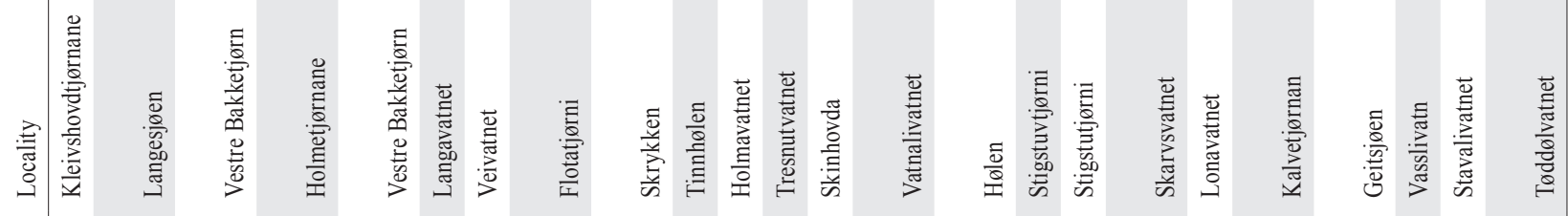

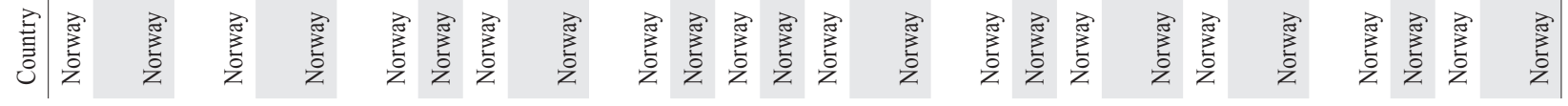




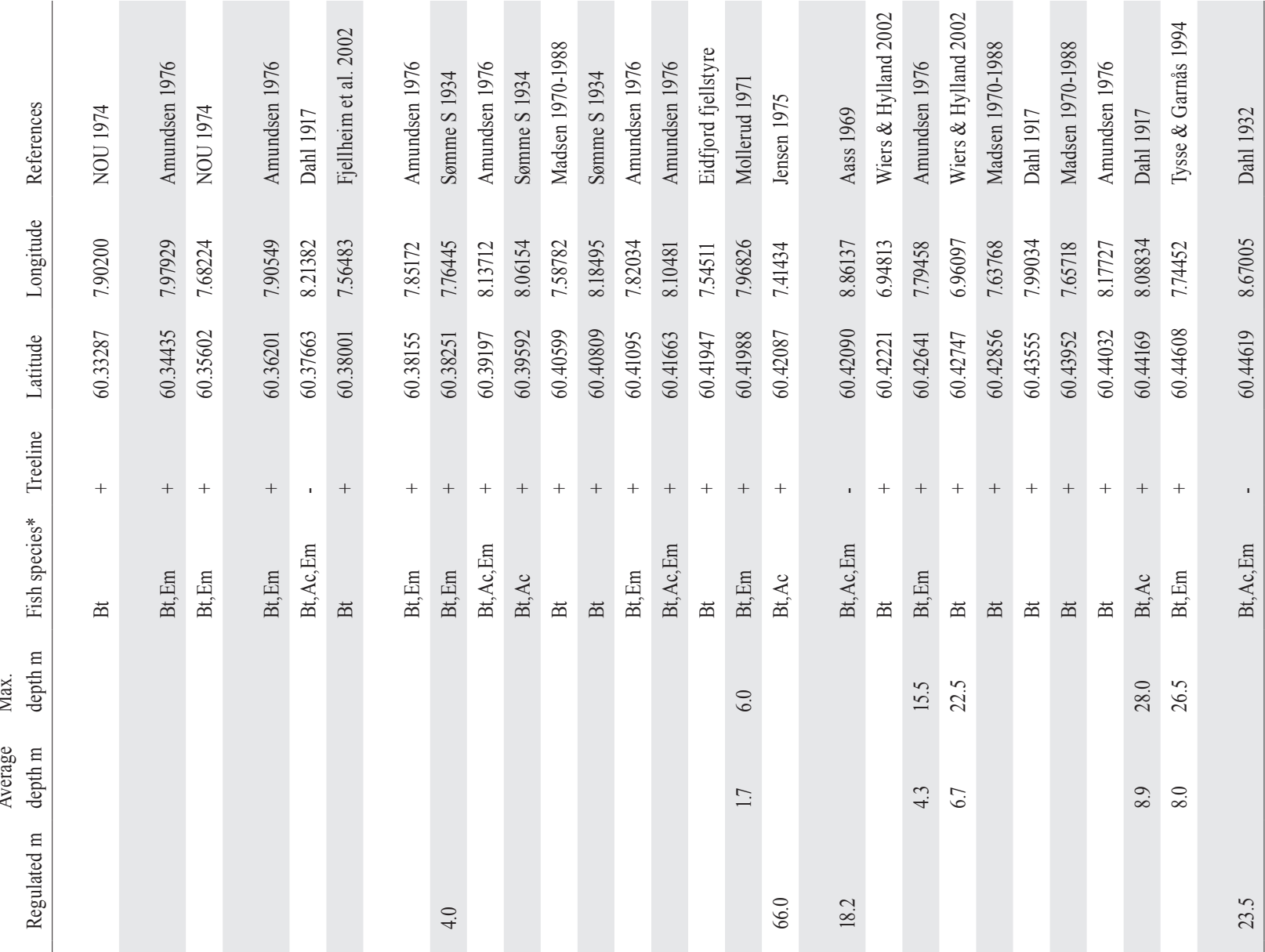

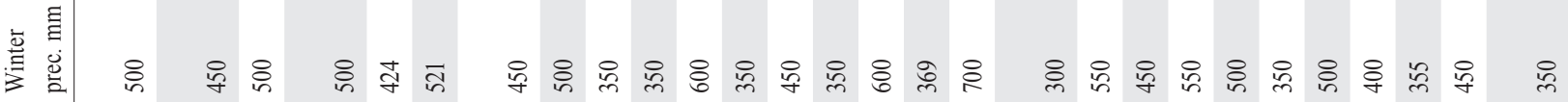

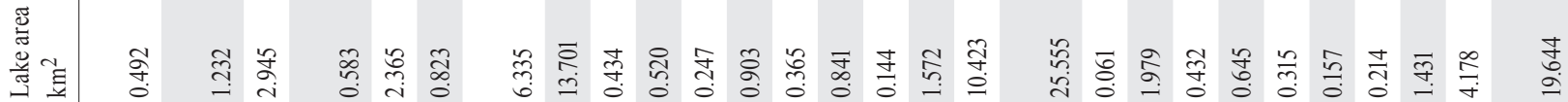

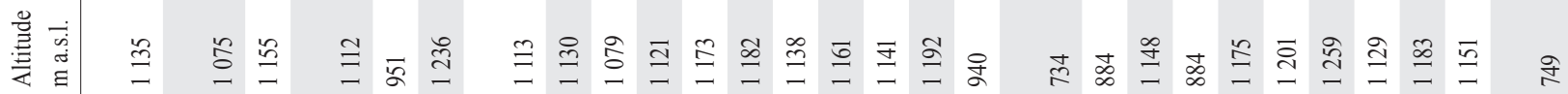

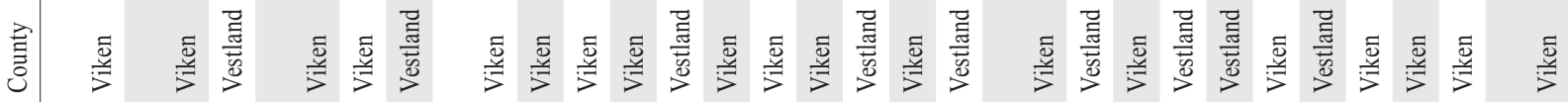

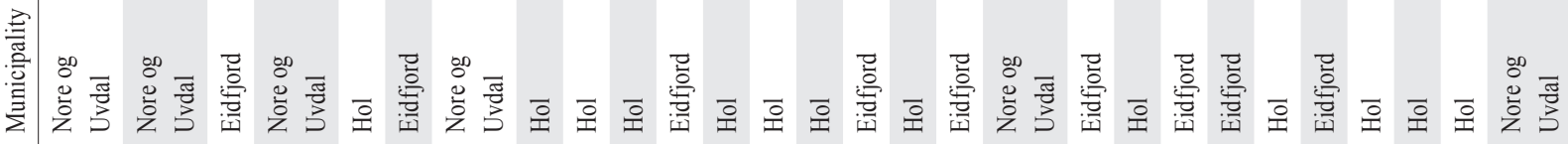

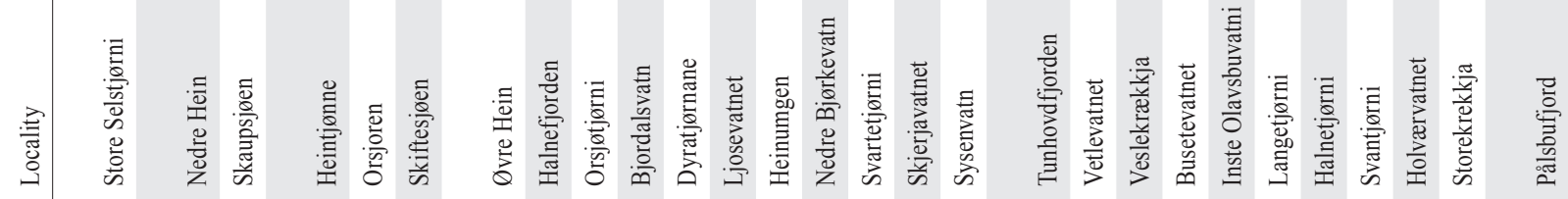

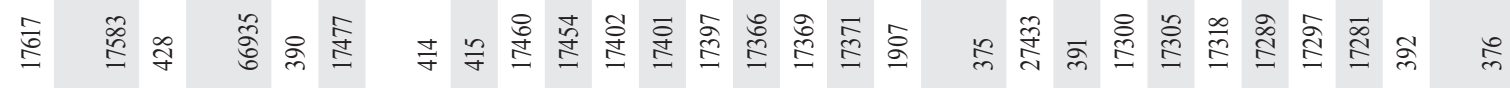

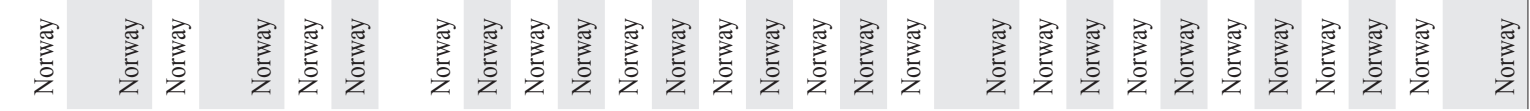




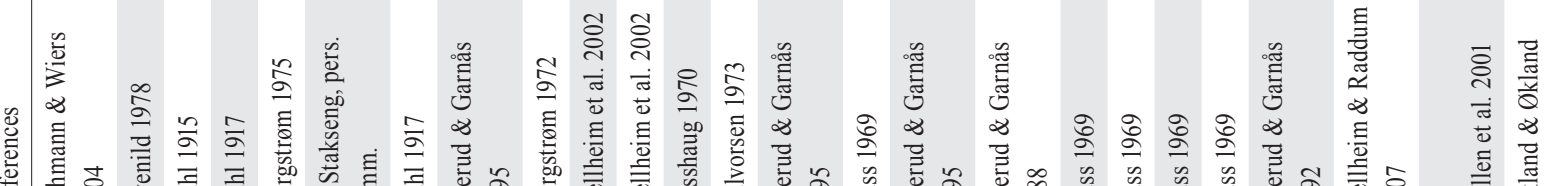

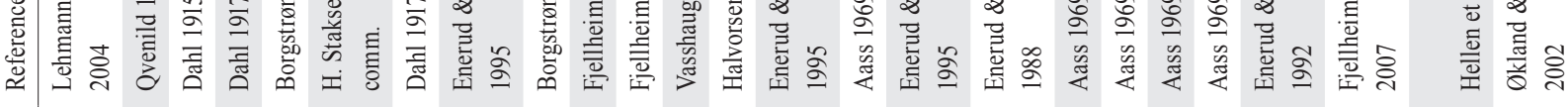

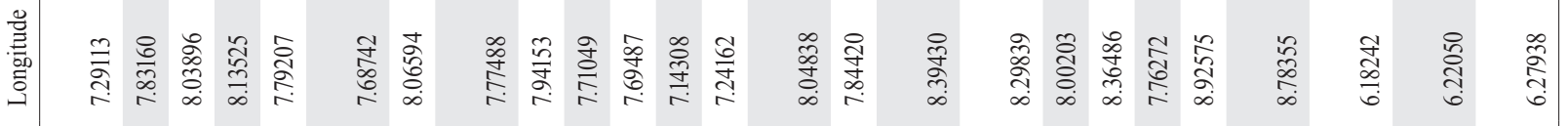

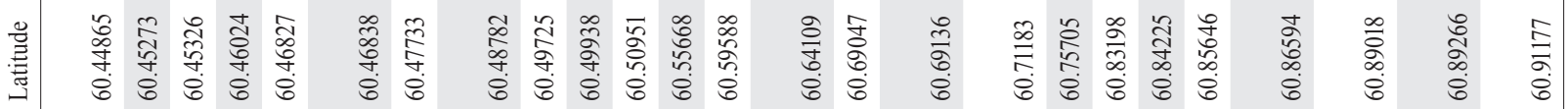

,

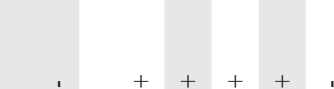

总

总焉

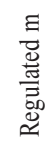
(1)

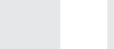

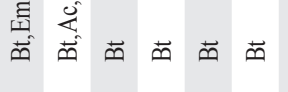

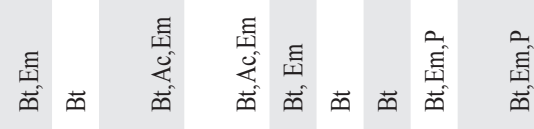

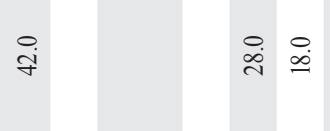

$\stackrel{\circ}{\infty} \stackrel{\dot{0}}{\infty}$

तें

울

$\stackrel{\circ}{\mathfrak{j}}$

$\stackrel{9}{\varrho} \quad$ فे $\stackrel{\infty}{+}$

$\therefore$

$\stackrel{i}{i}$

$m$

音竞

$\stackrel{\circ}{\oplus}$

$\stackrel{\circ}{\cong} \stackrel{\circ}{\circ}$

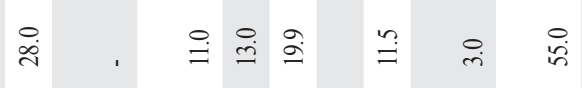

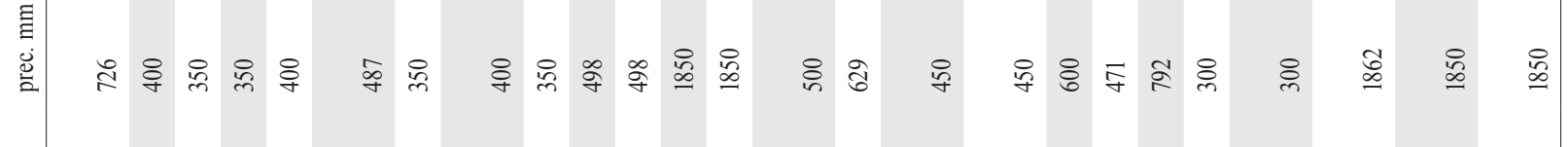

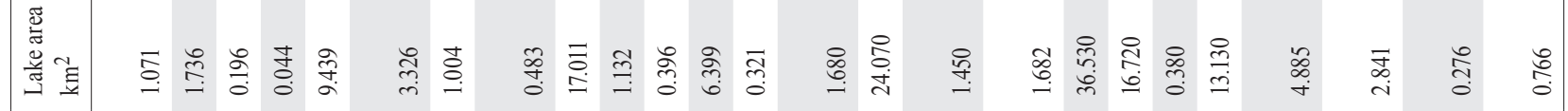

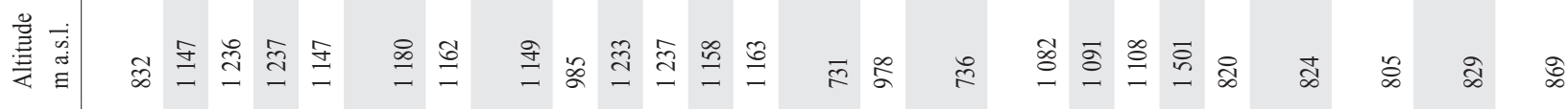

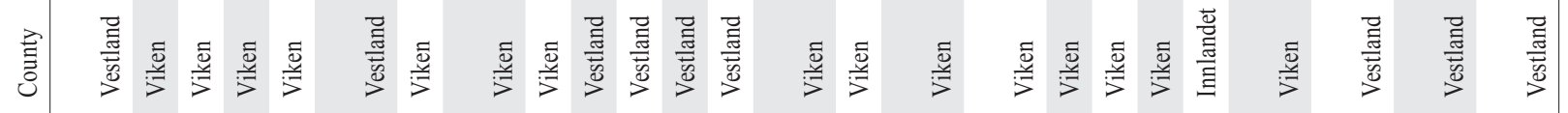

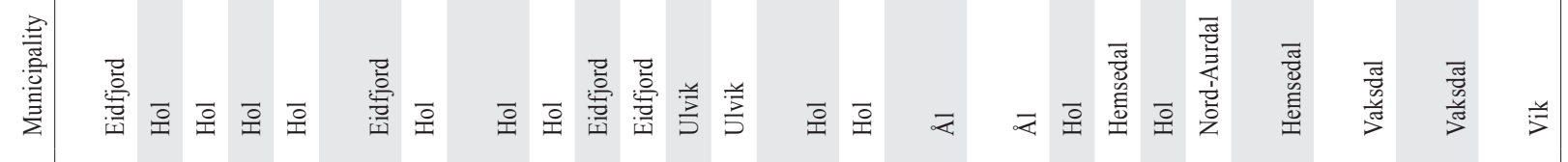

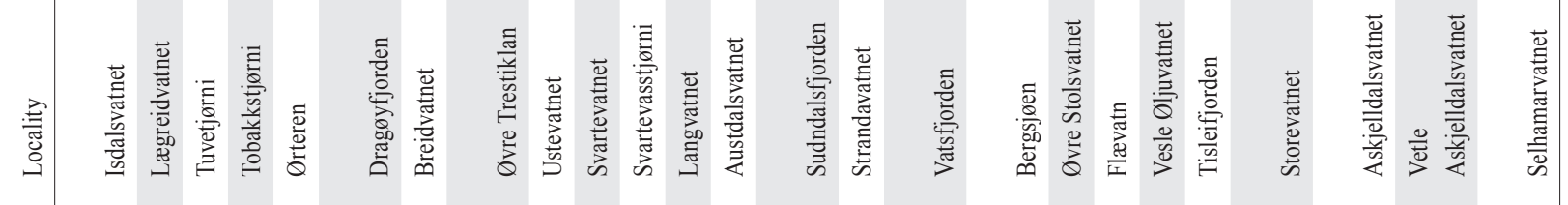

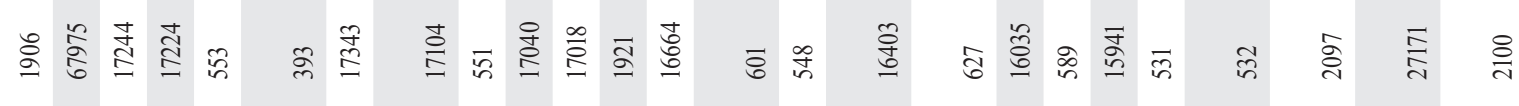

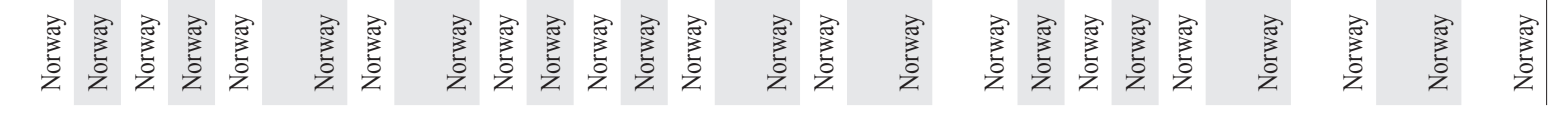




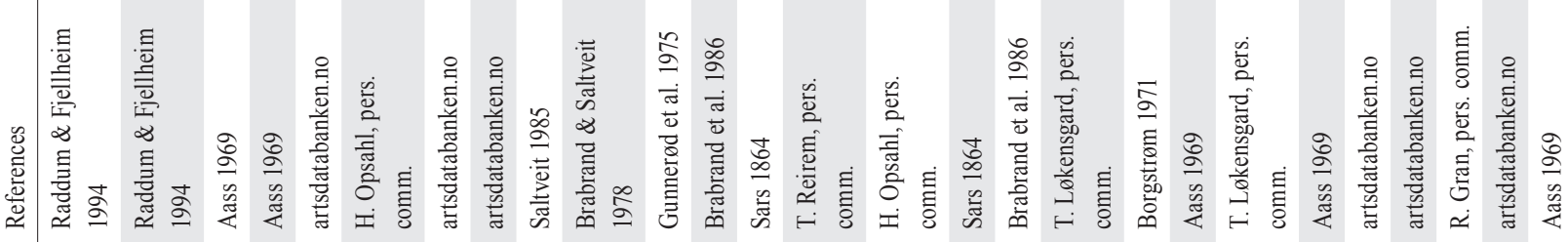

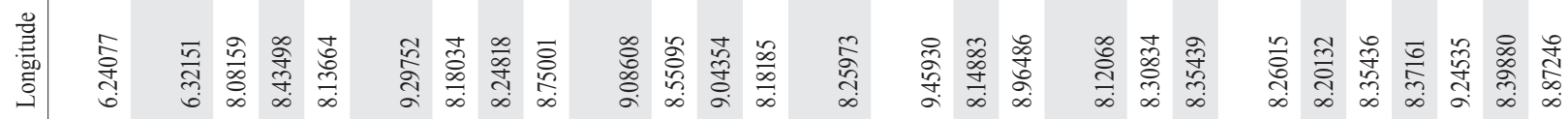

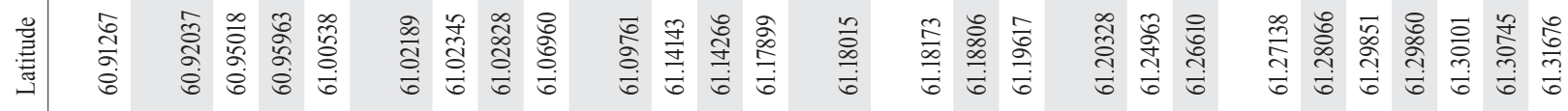

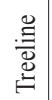

*.

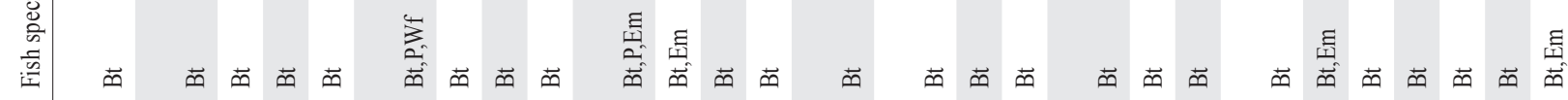

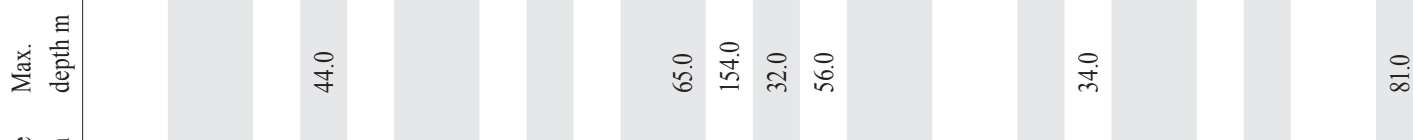

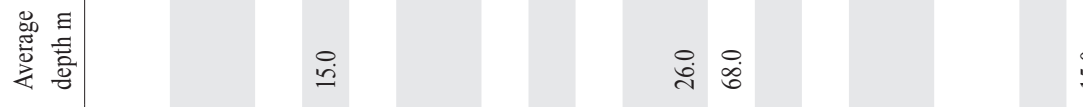

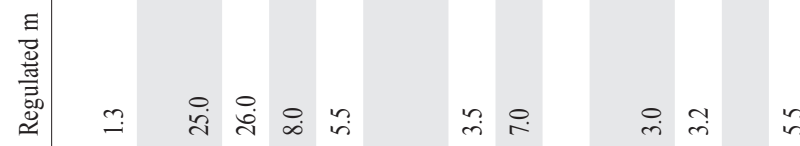

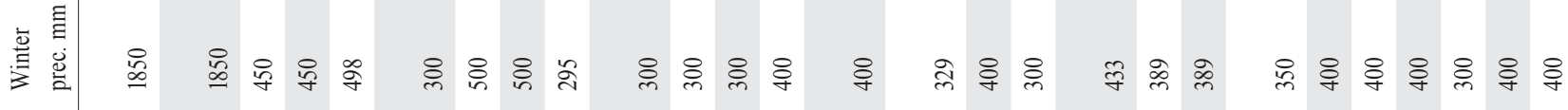
䮈

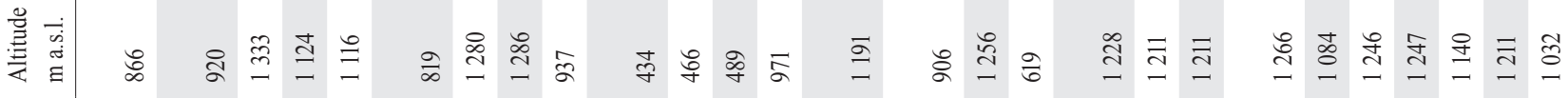

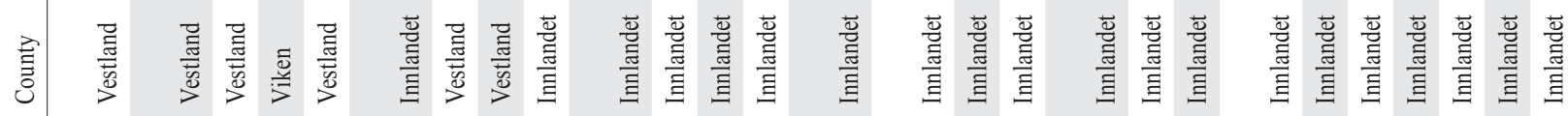
蛋

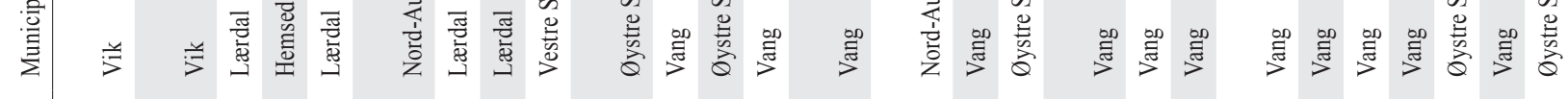

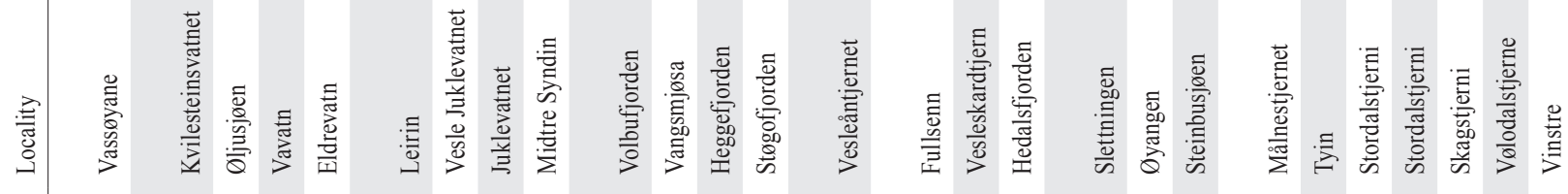

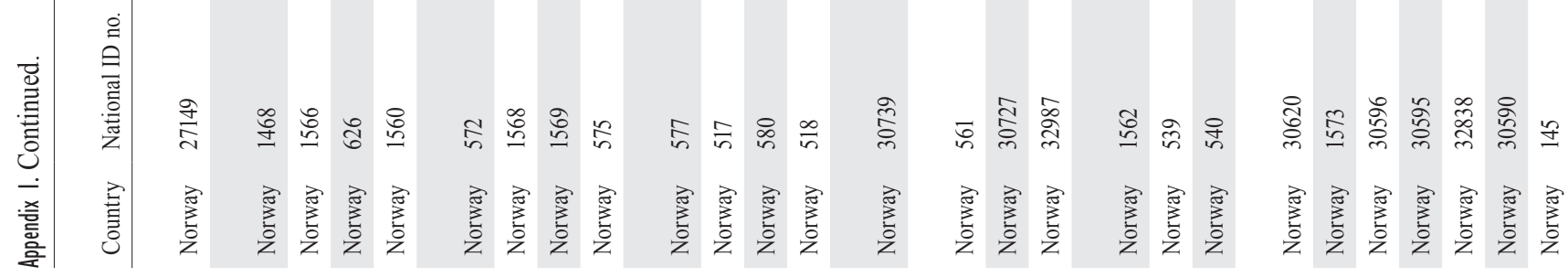




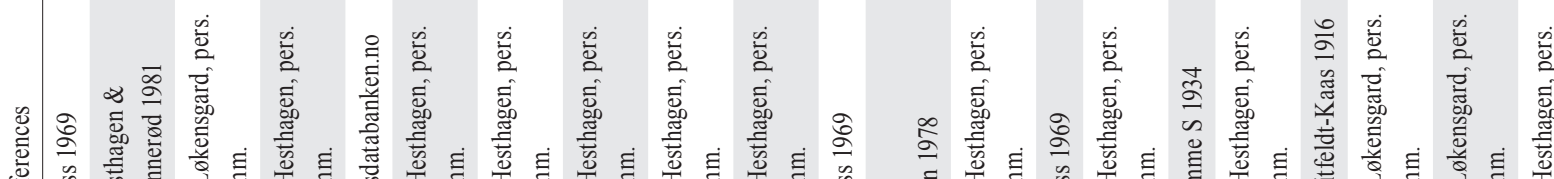

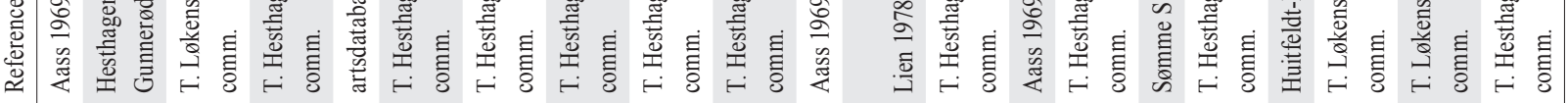

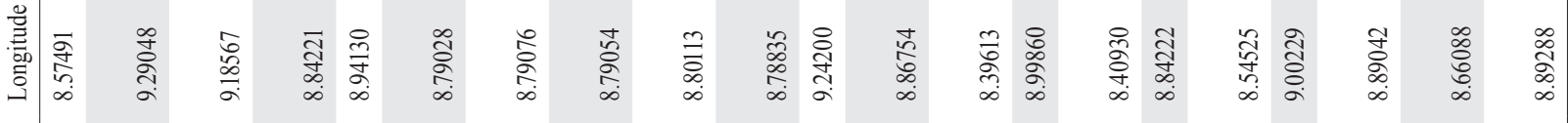

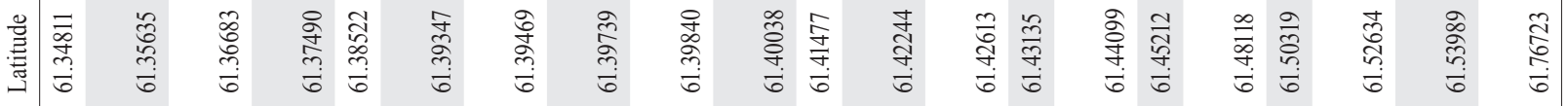

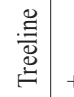

$\frac{*}{3}$

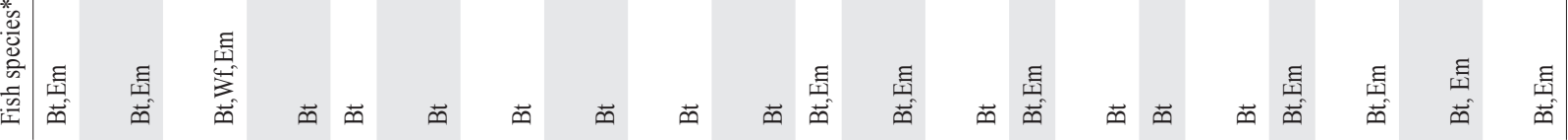
总言紊竞

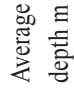

章

声

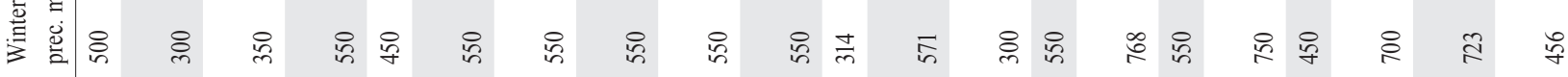

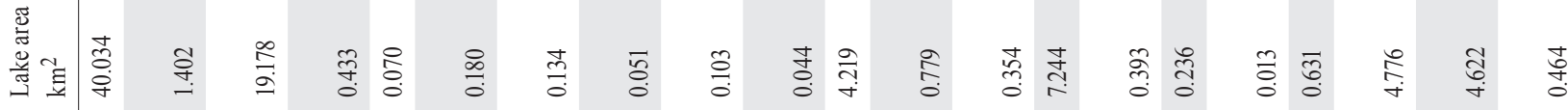

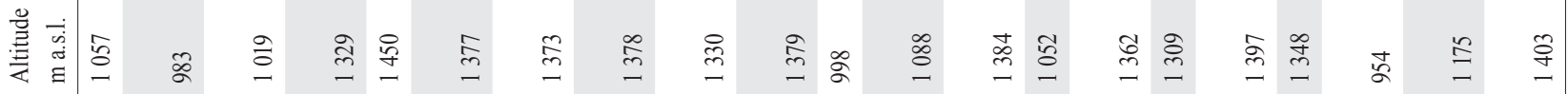

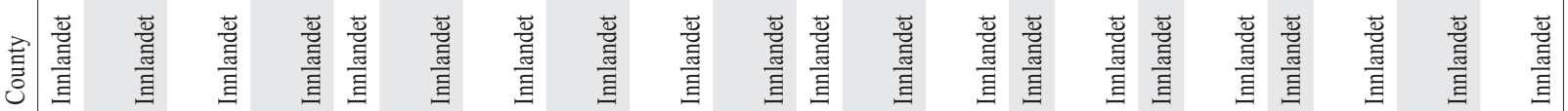

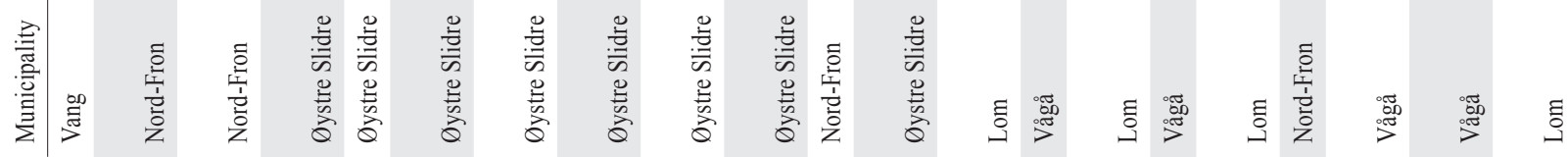

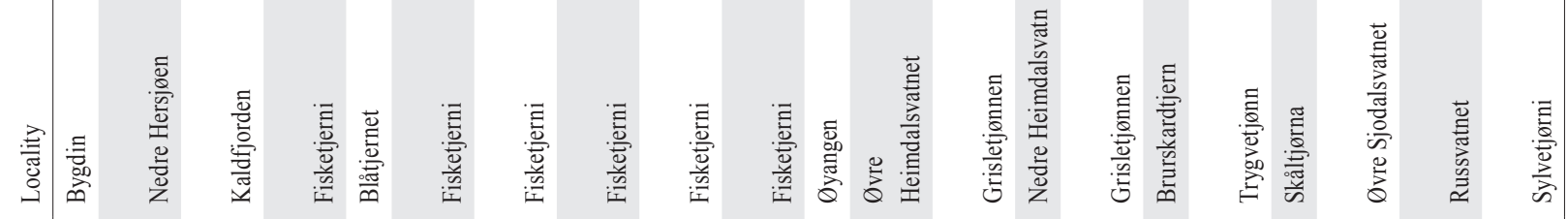

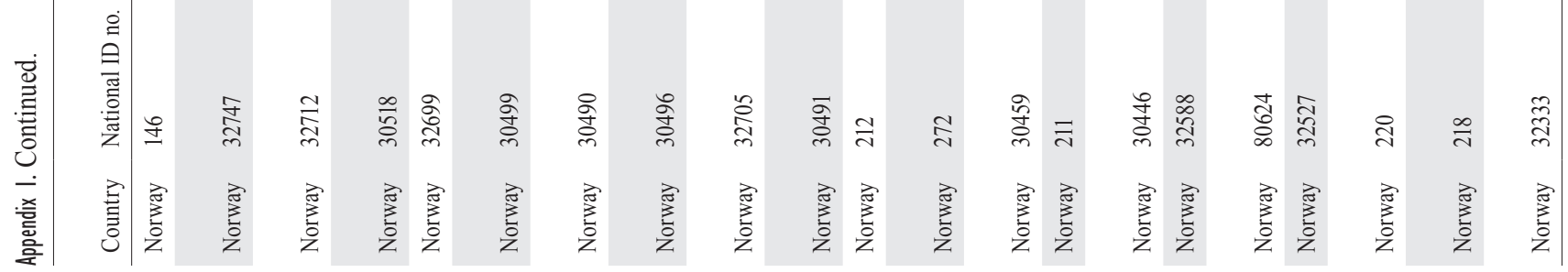




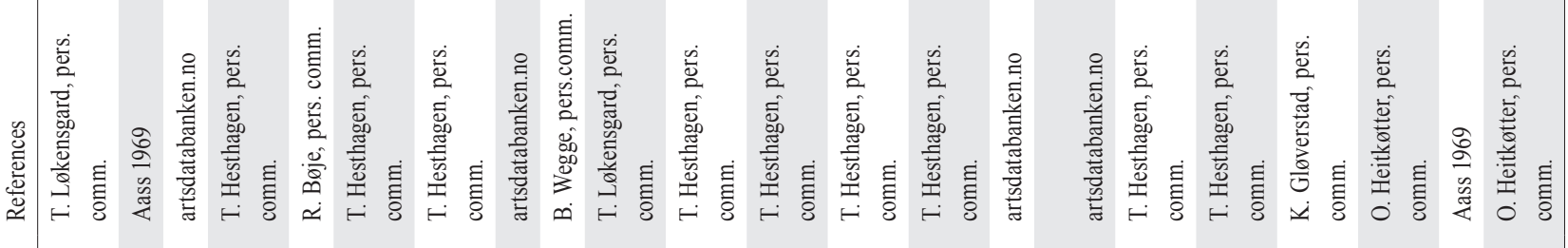

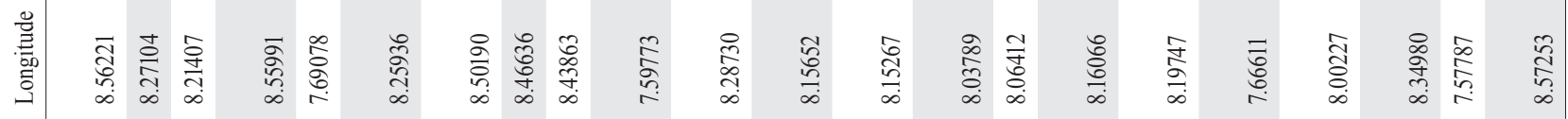

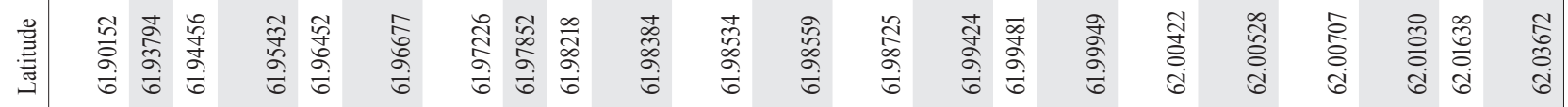

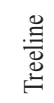
茪

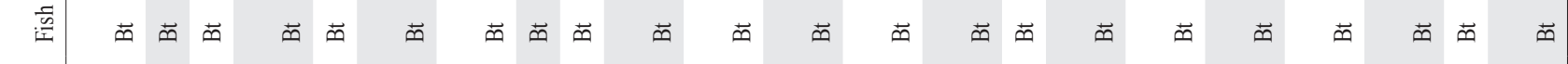
$\stackrel{\Xi}{\stackrel{\Xi}{*}}$

焉焉

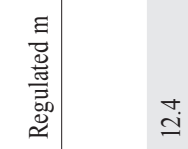

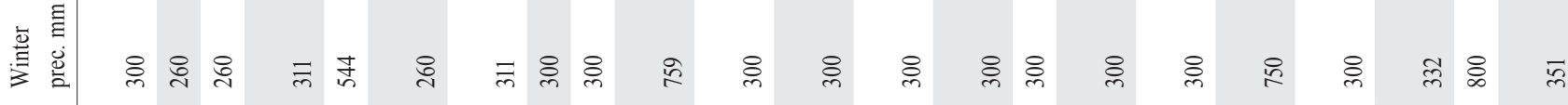
㺃

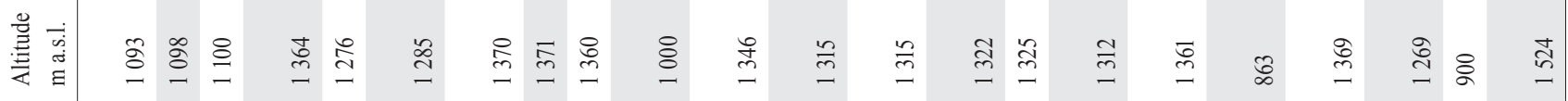

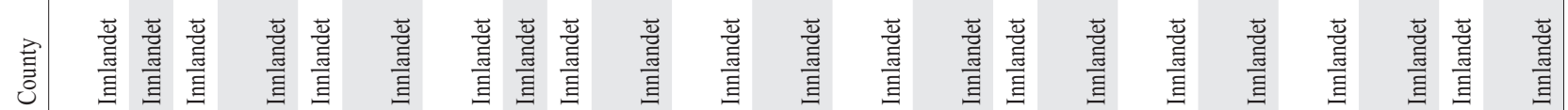

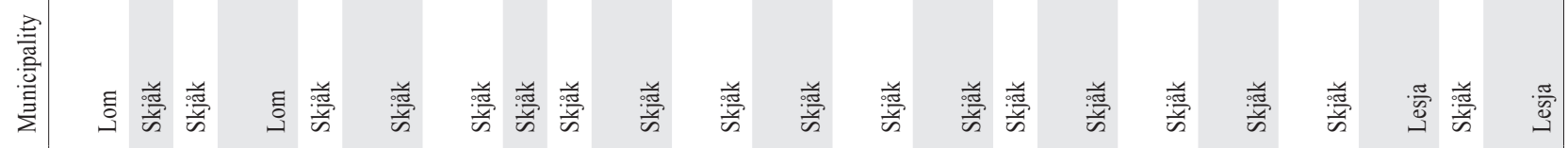

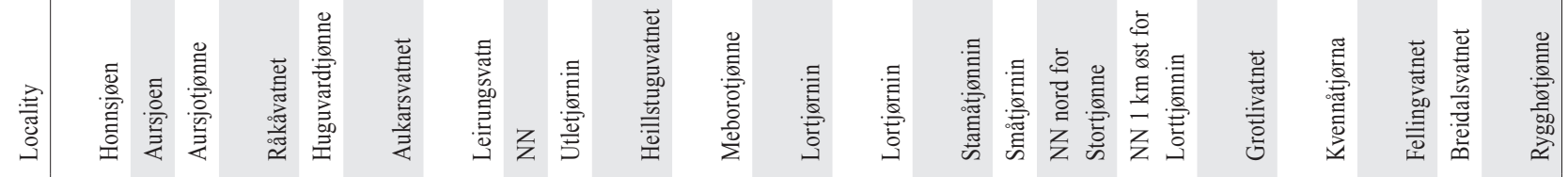

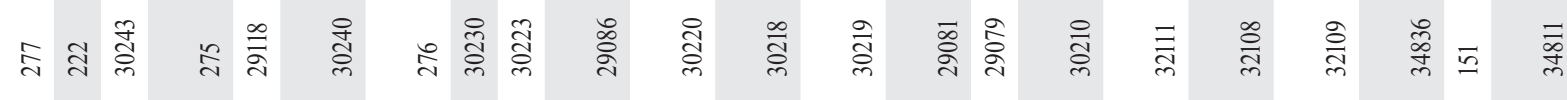

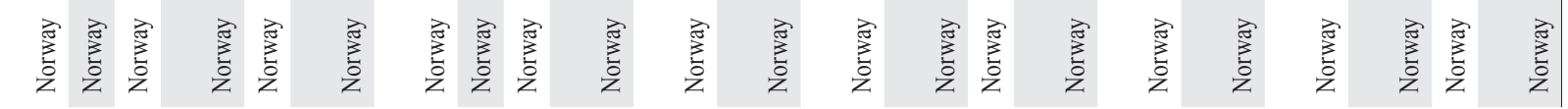




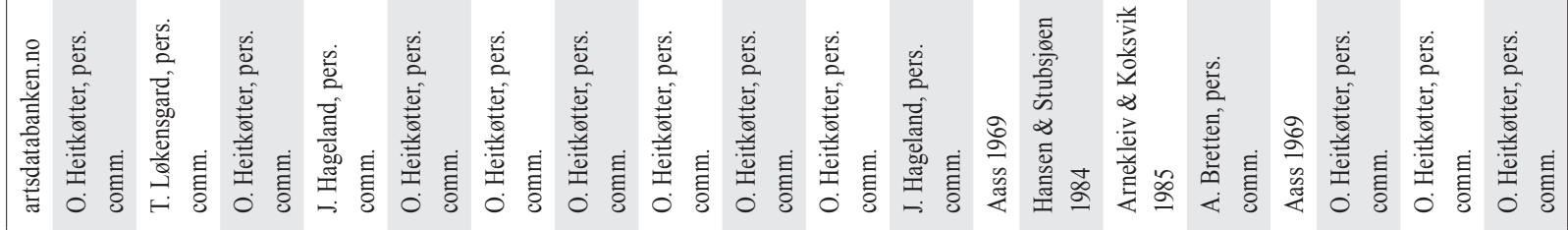

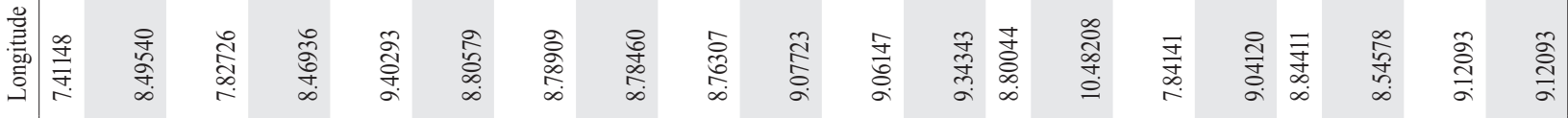

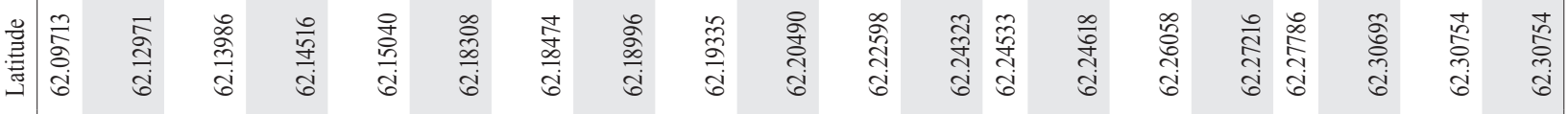
默

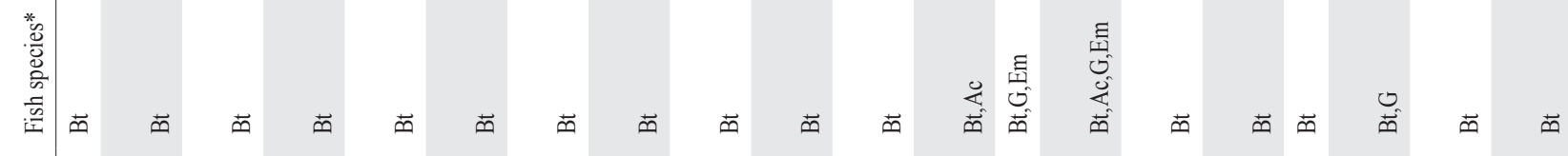

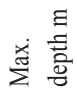

窟

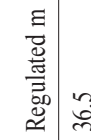

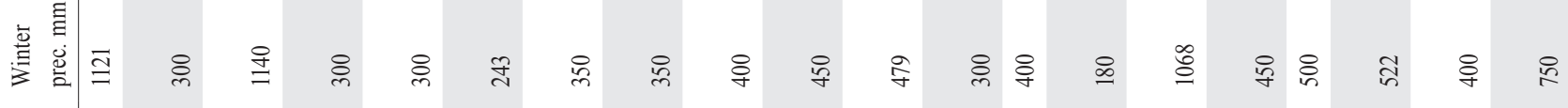

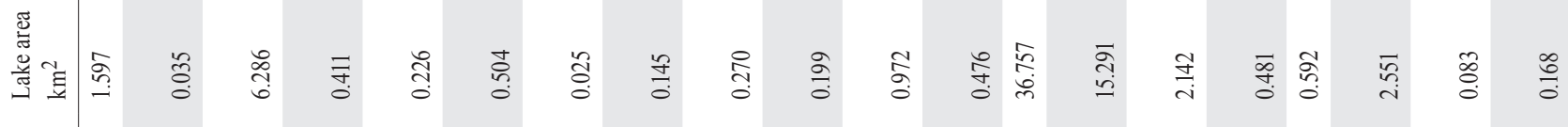

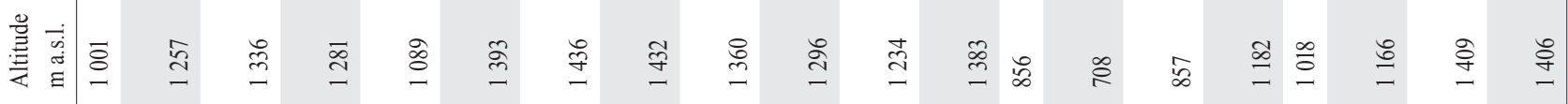

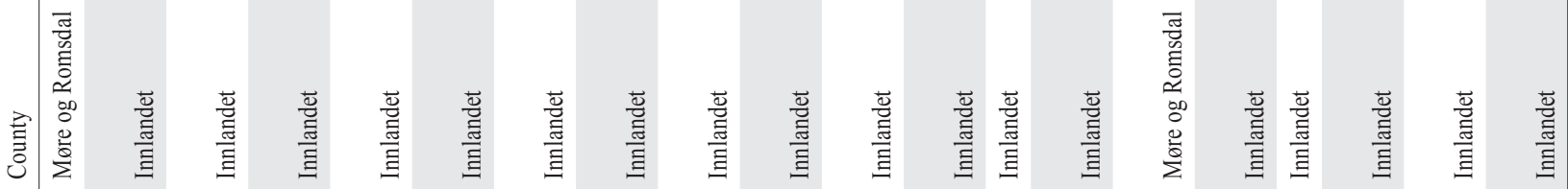

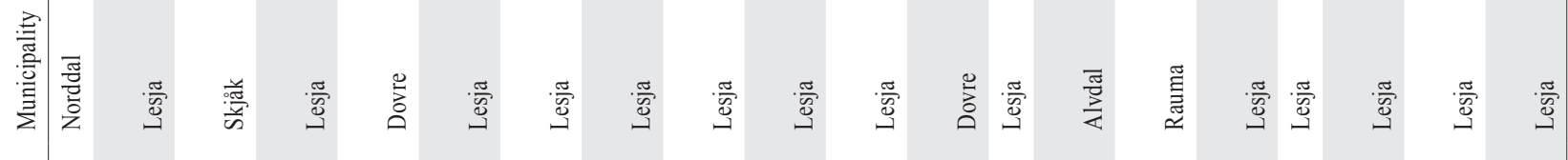

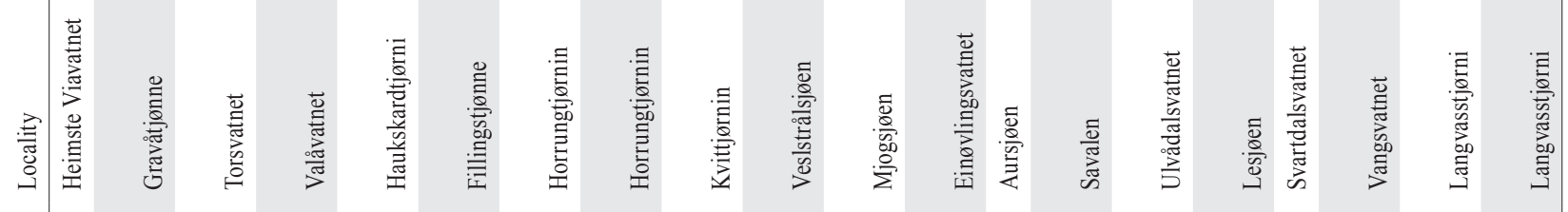

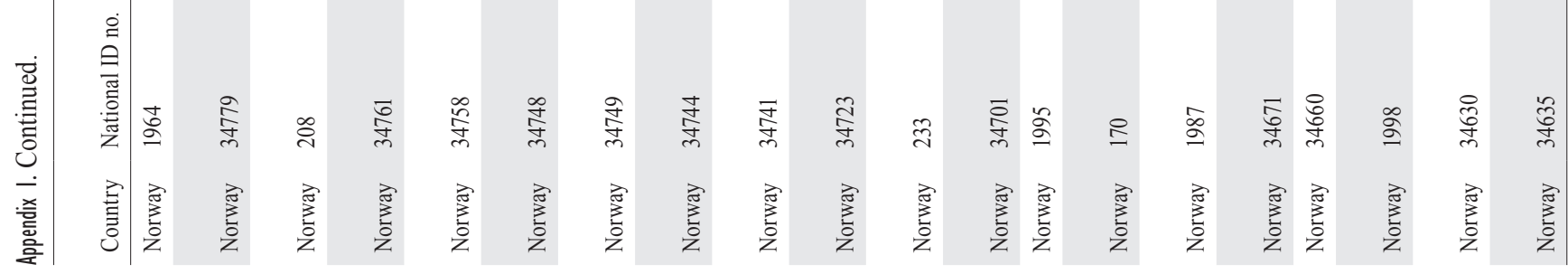




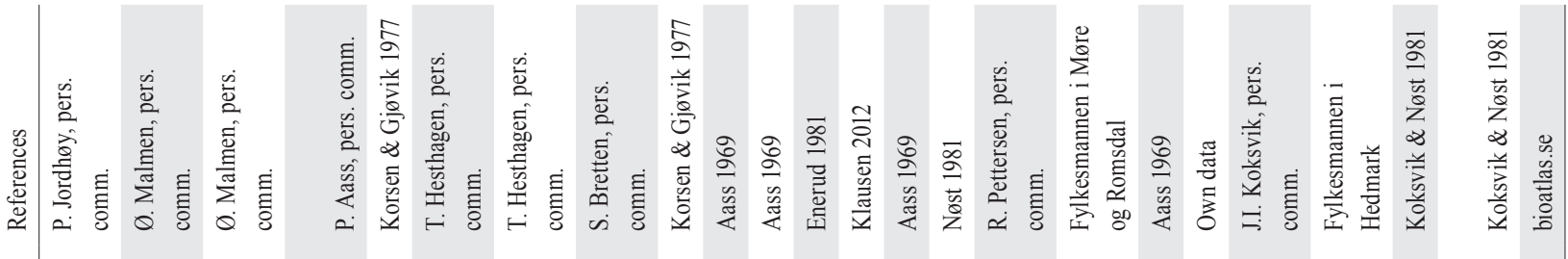

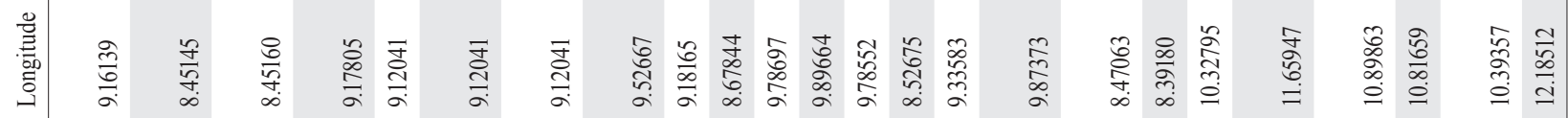

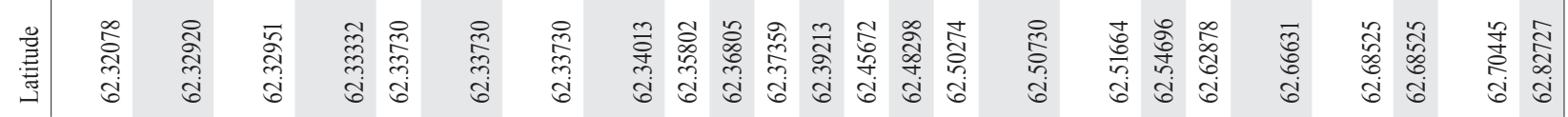

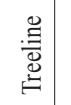

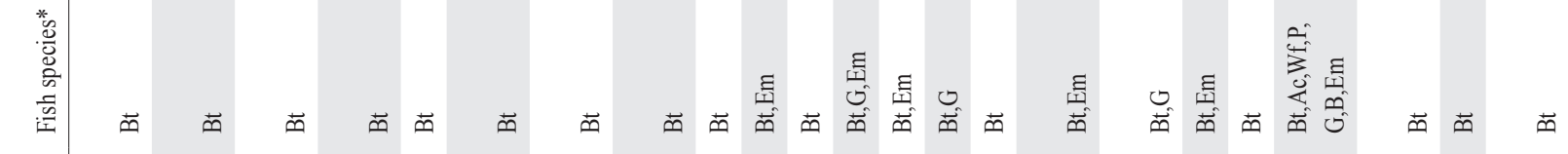

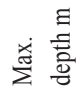

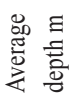

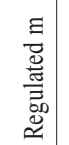

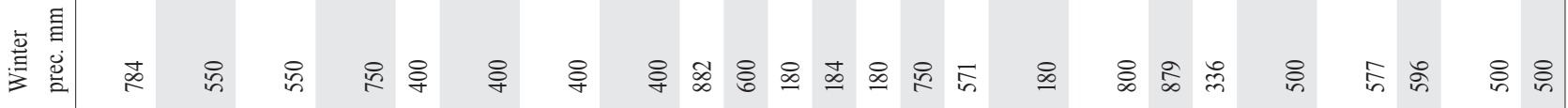

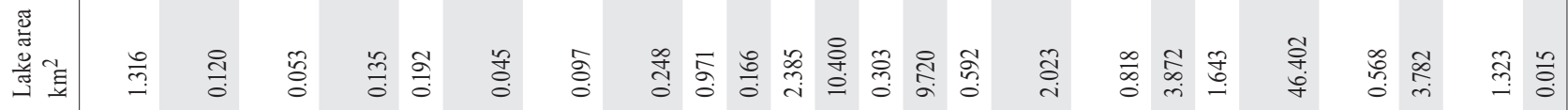

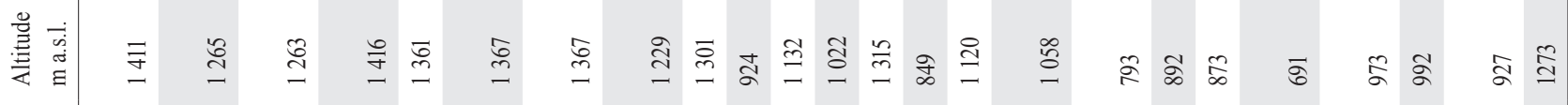

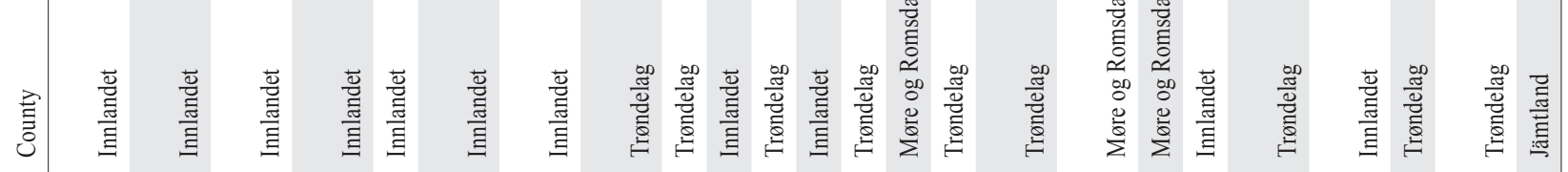

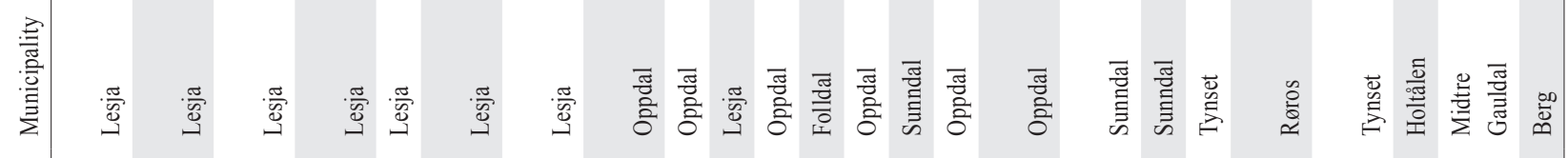

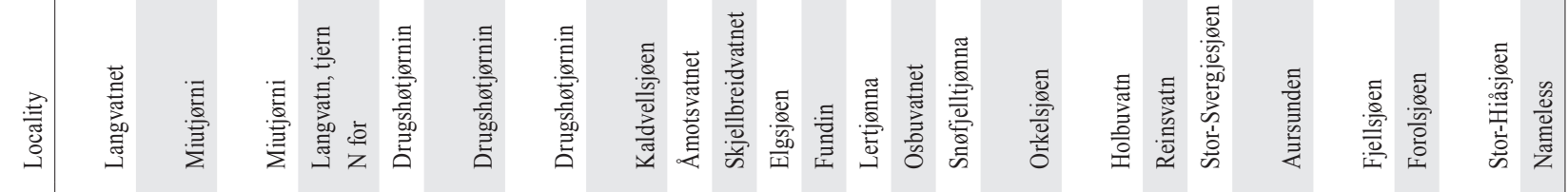

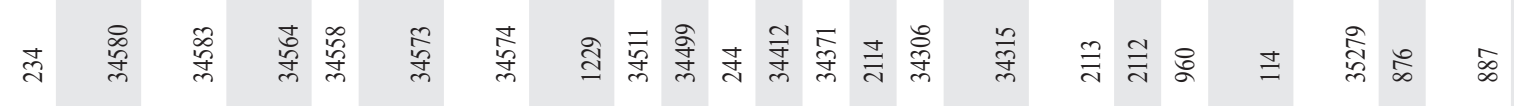

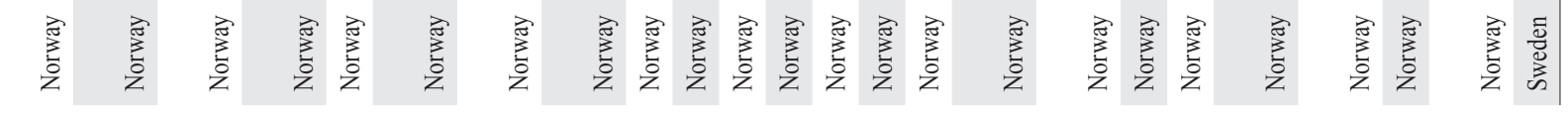




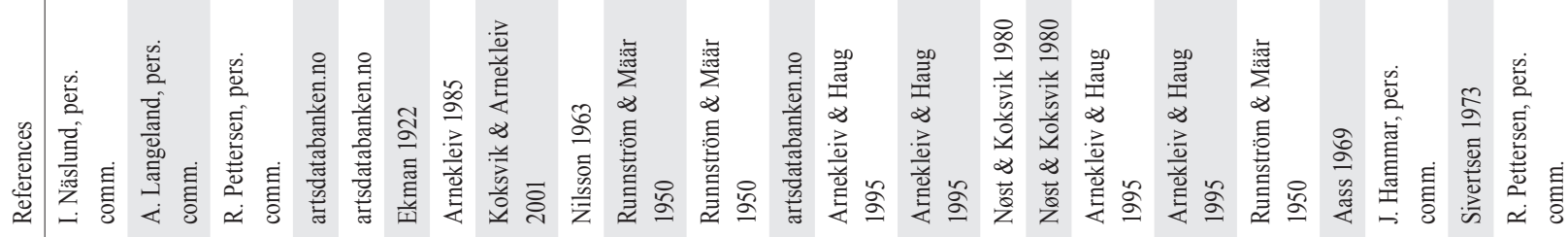

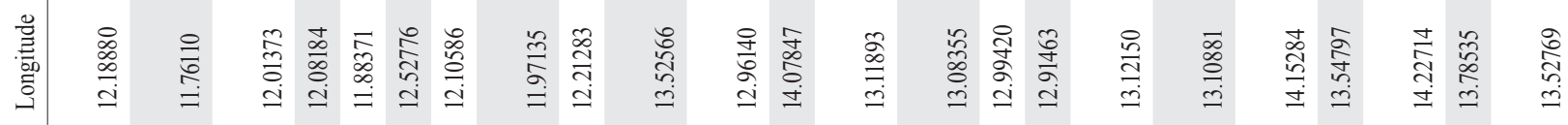

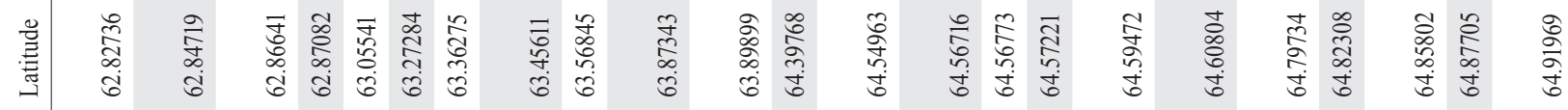

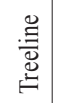

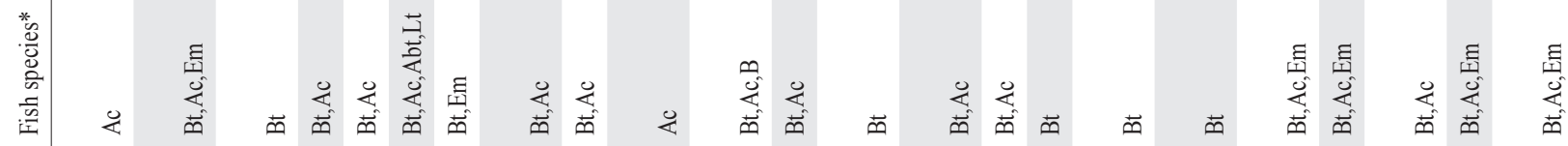
紊 密

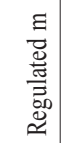

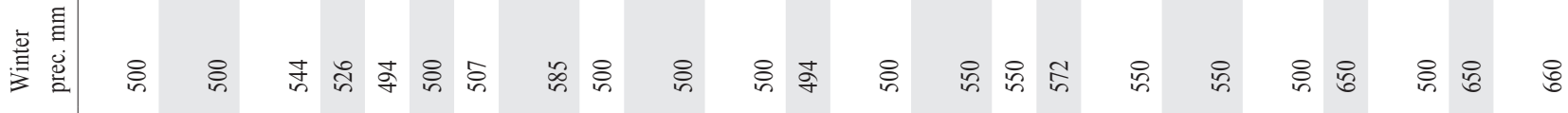

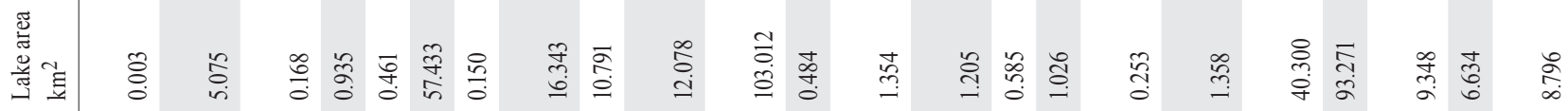

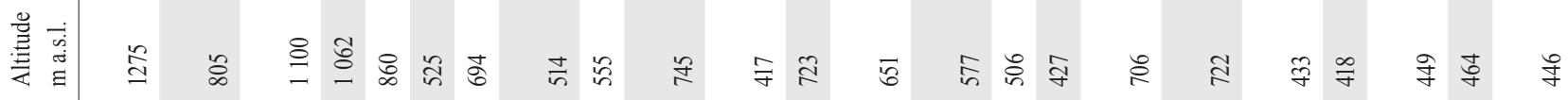

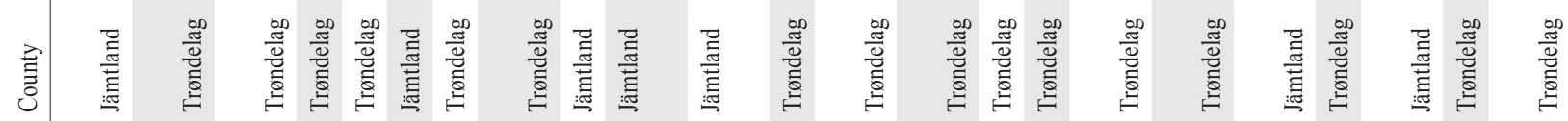

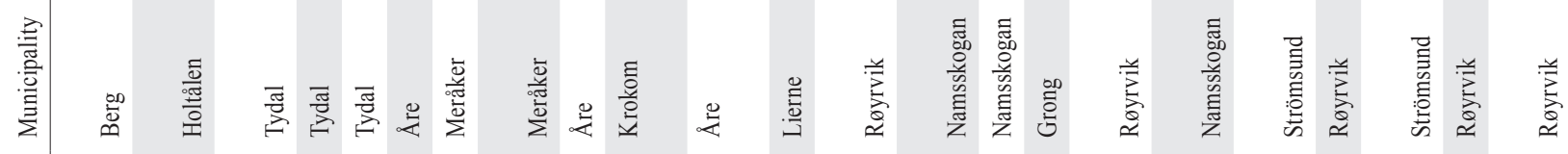

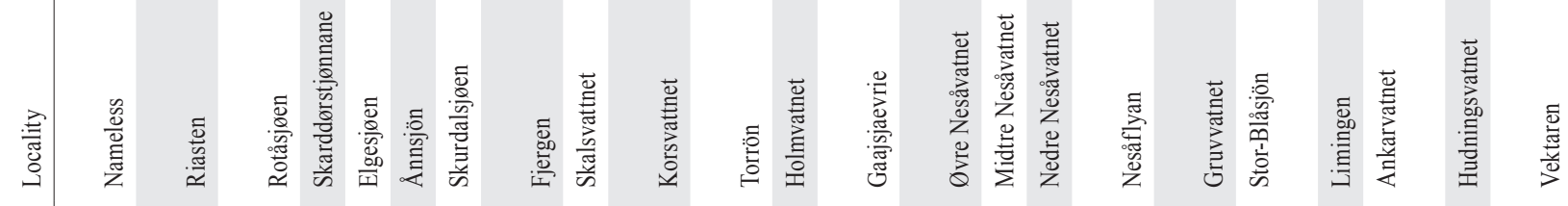

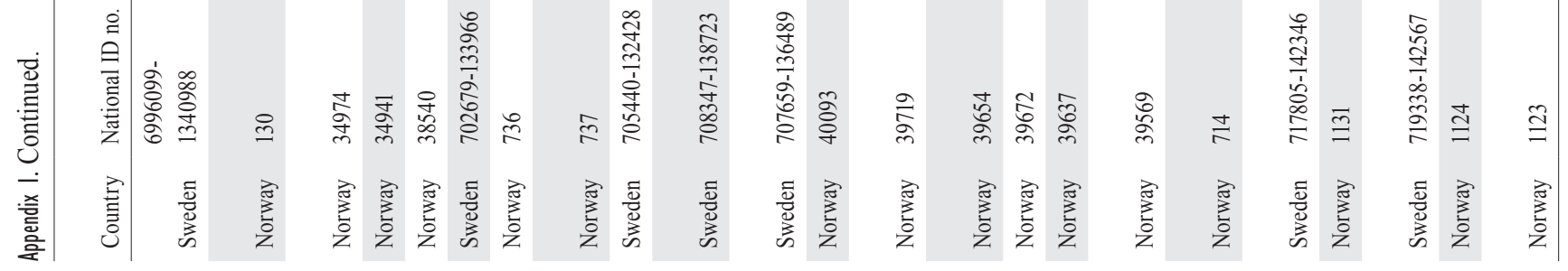




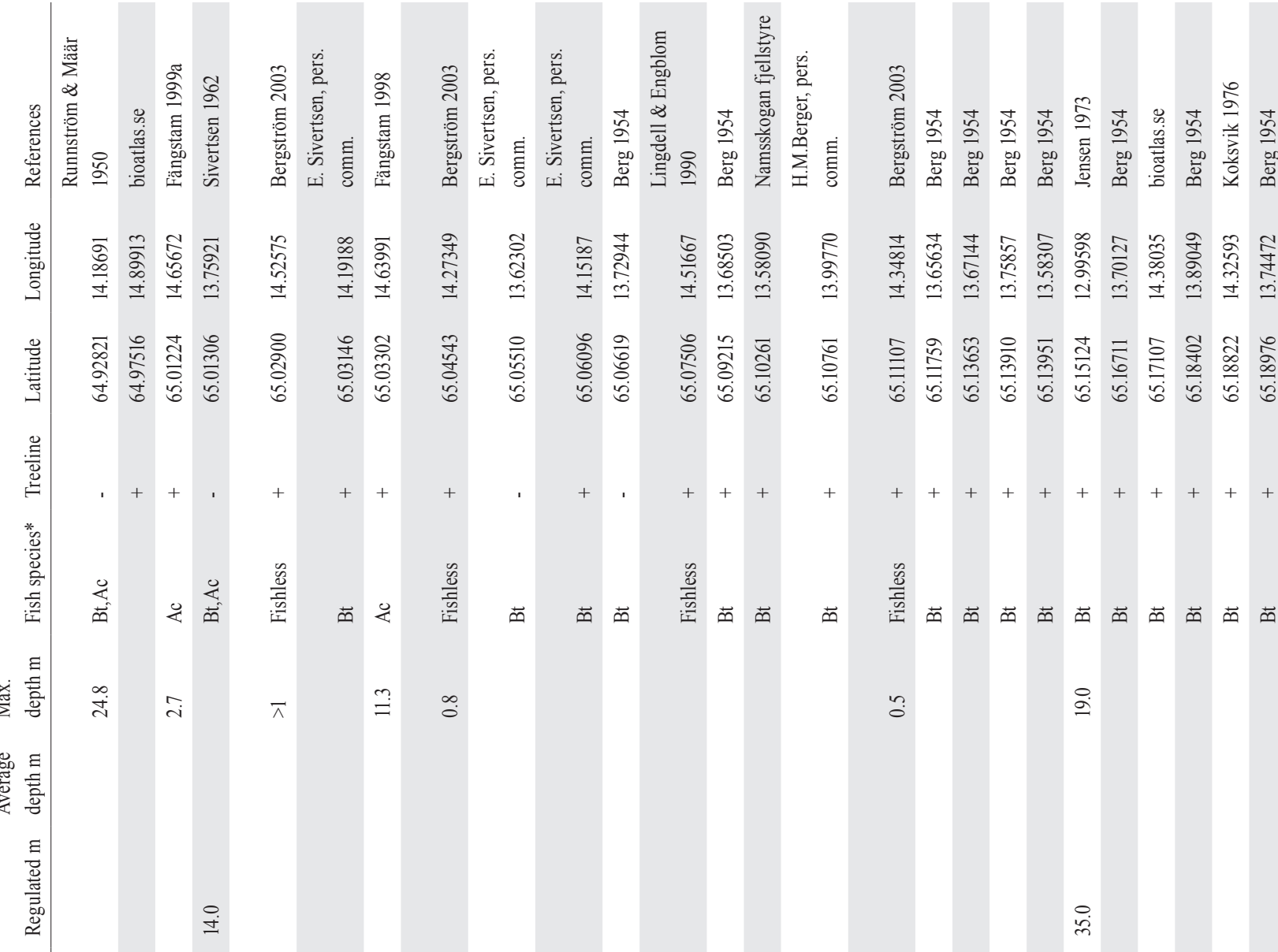

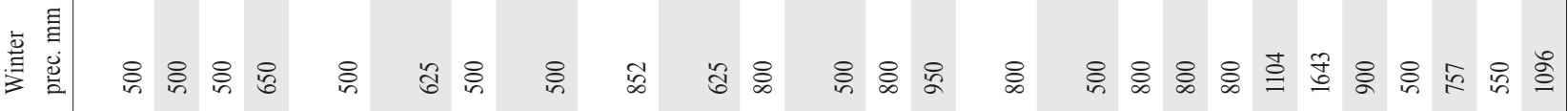

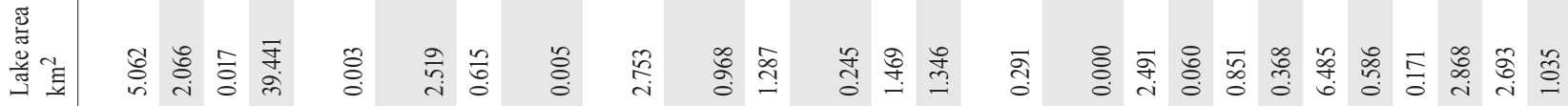

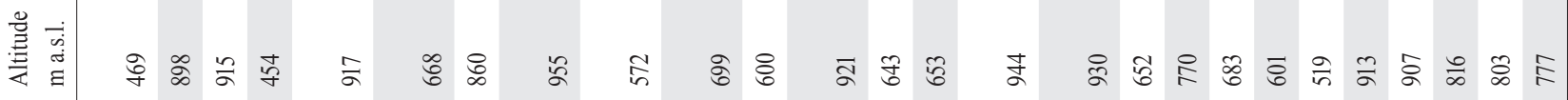

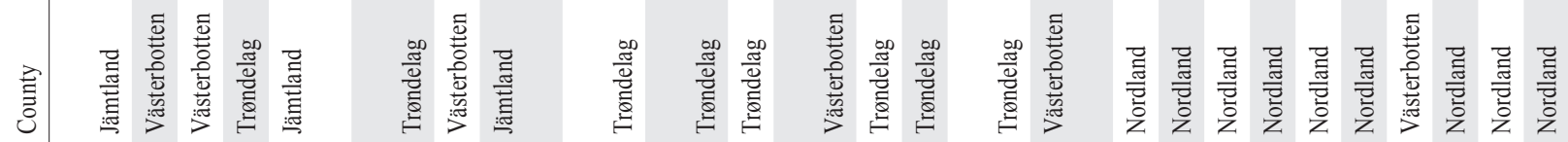

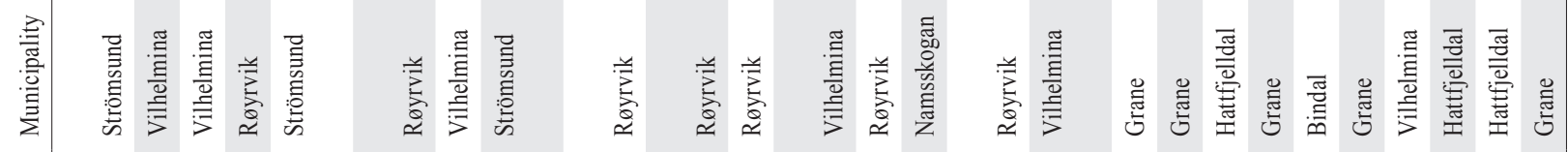

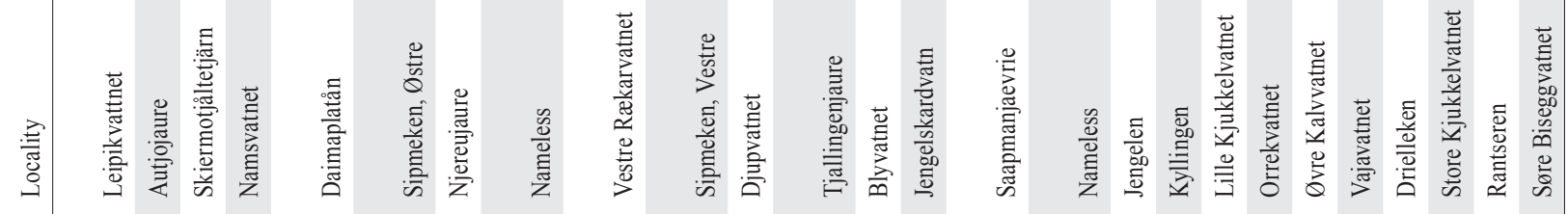

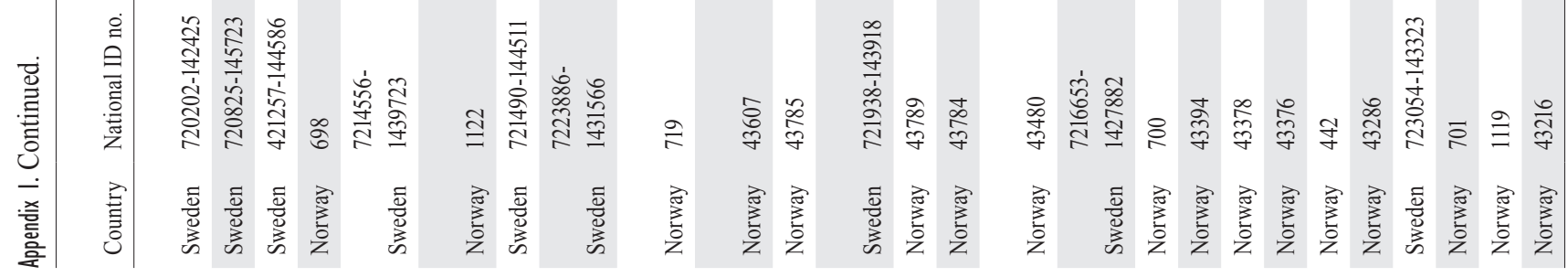




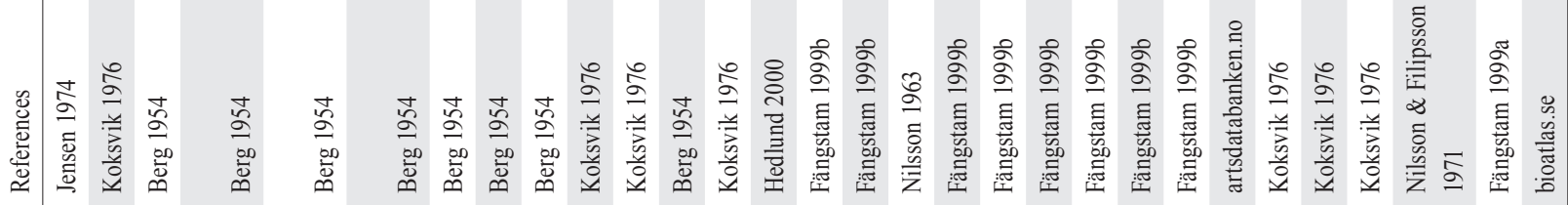

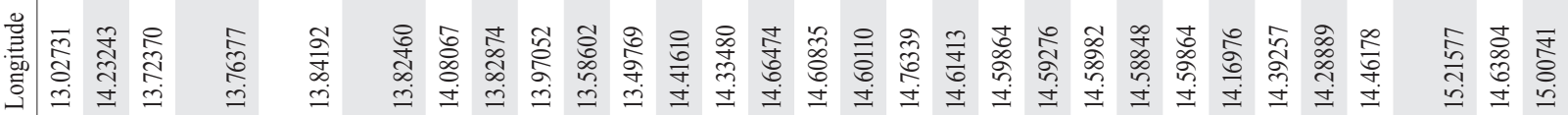

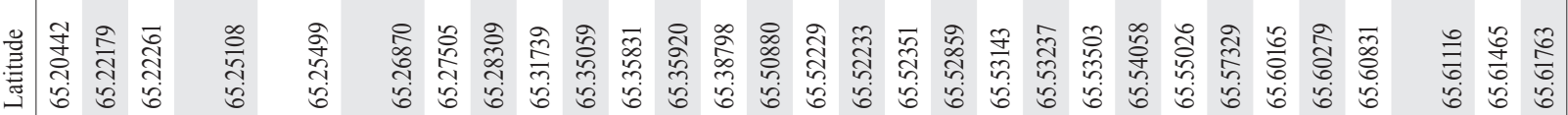
恚

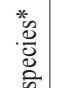

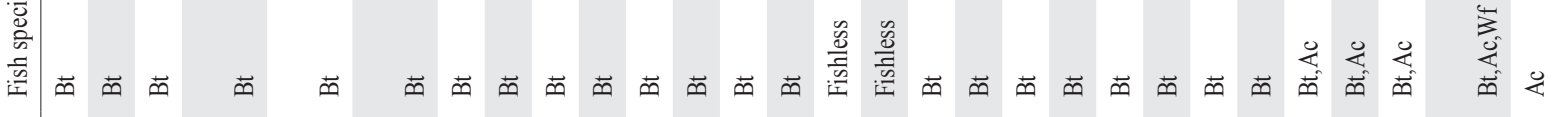
产 言紊完

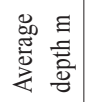

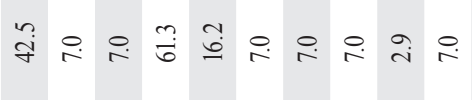
约 $\stackrel{\Xi}{9}$ ్ㅗㅇ

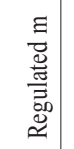

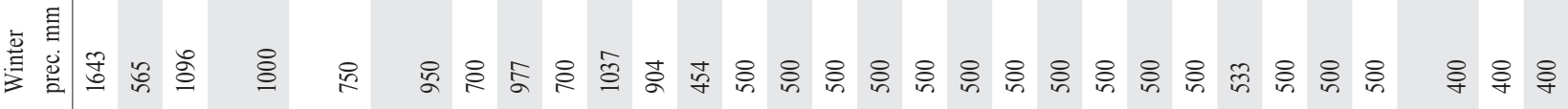

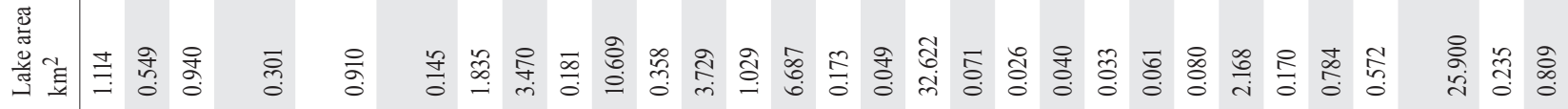

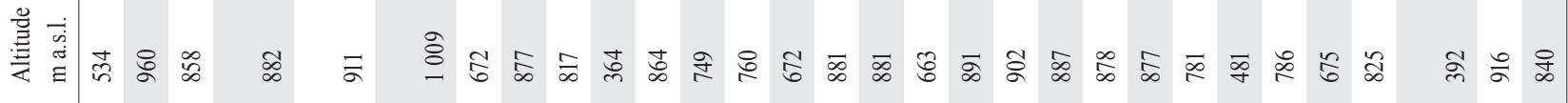

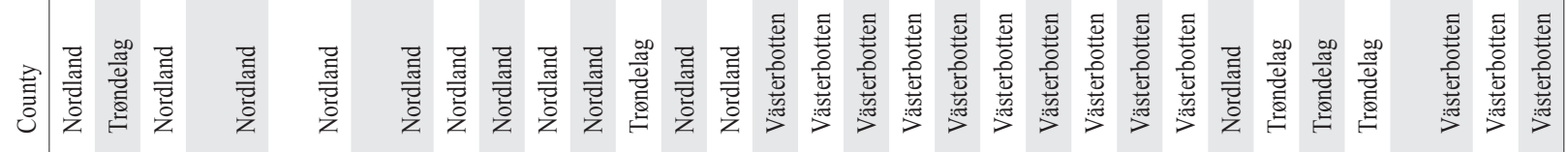

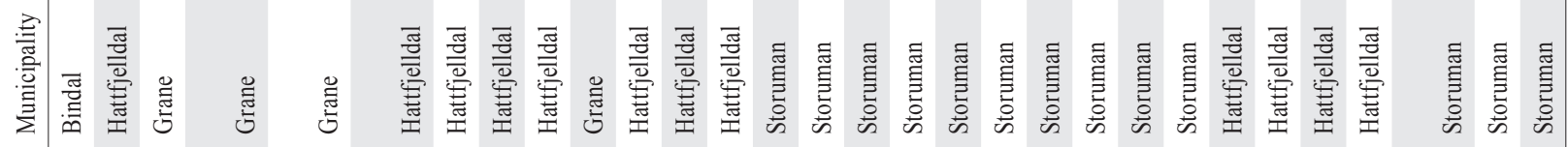

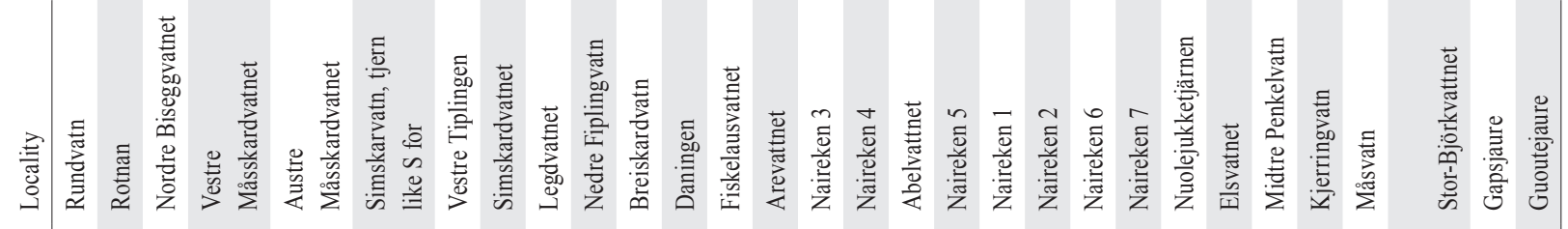

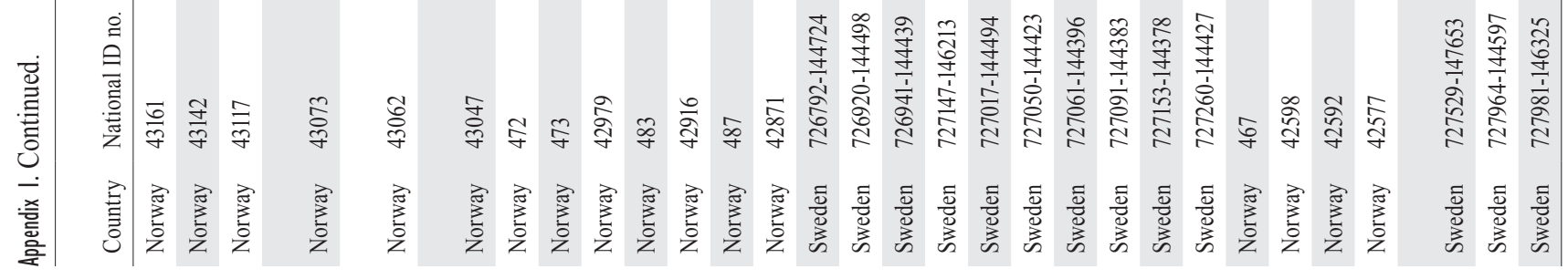




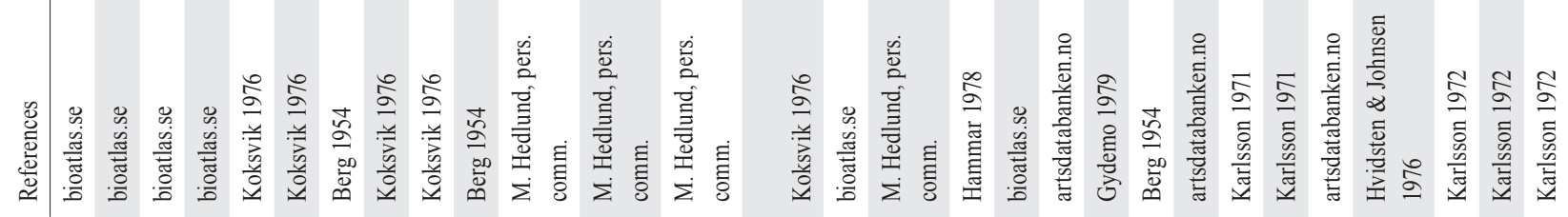

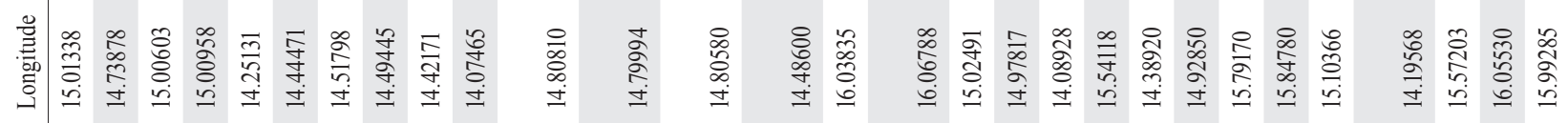

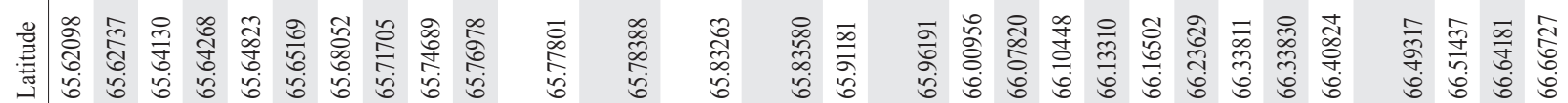
莺

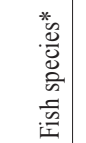

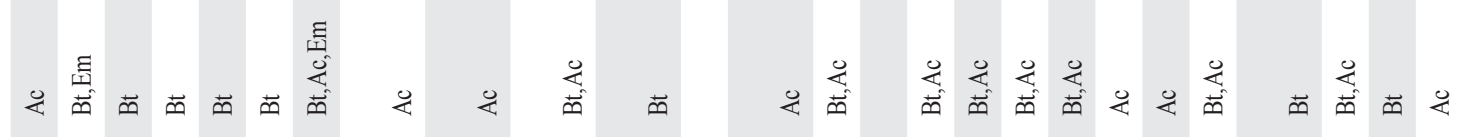

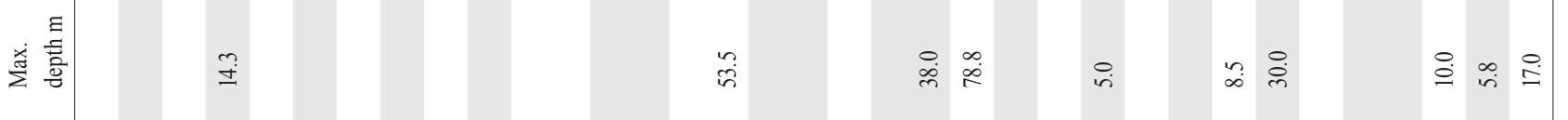

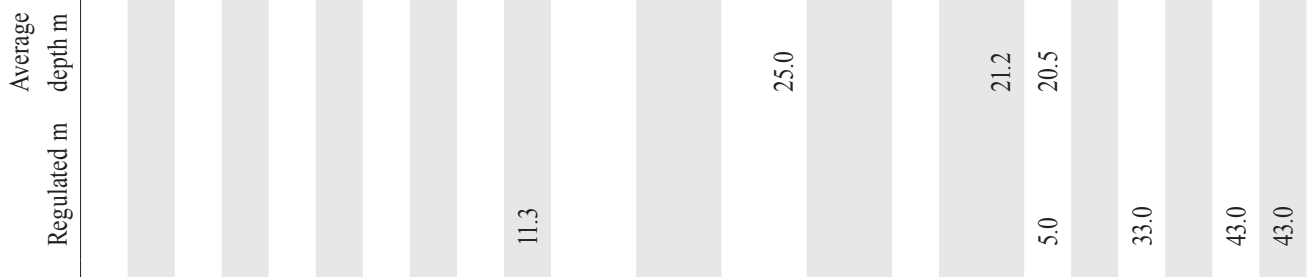

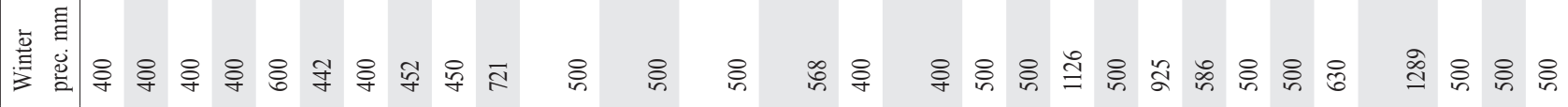
焉

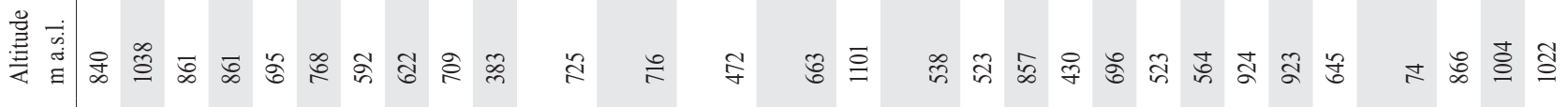

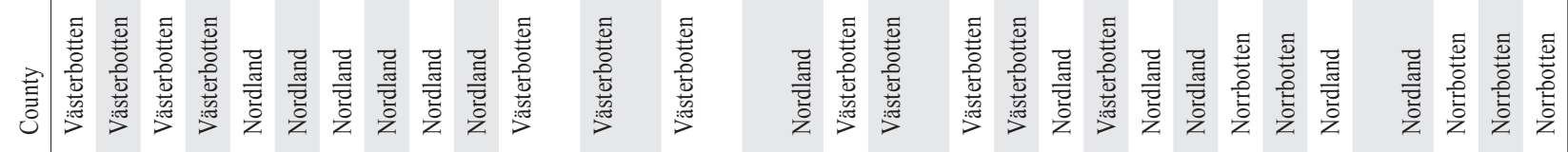

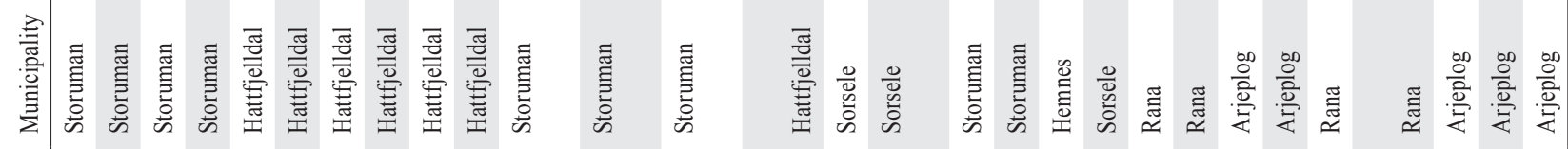

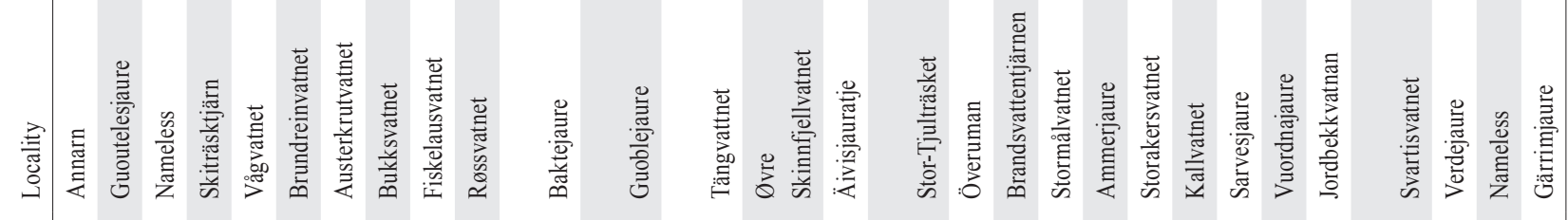

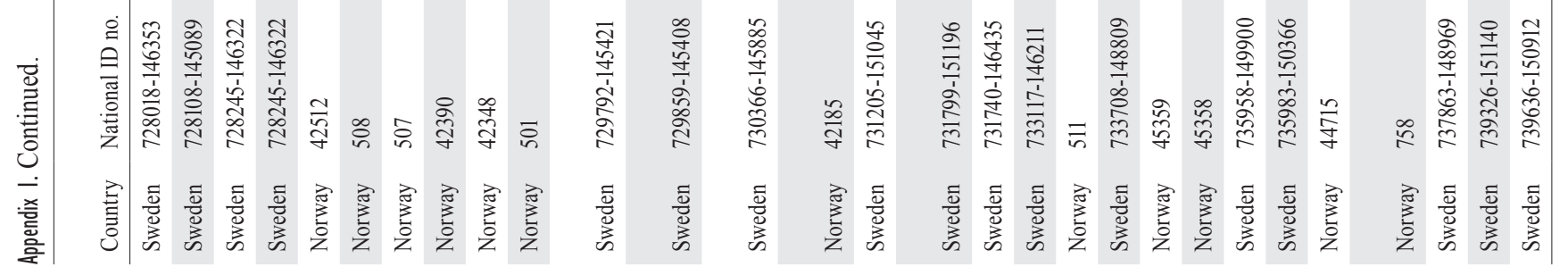




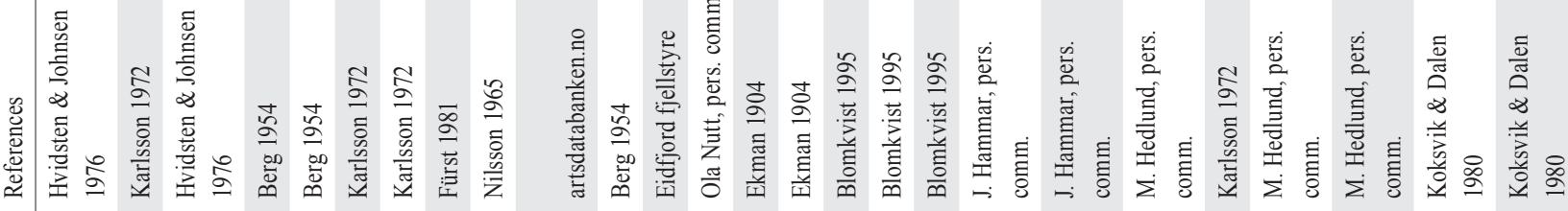

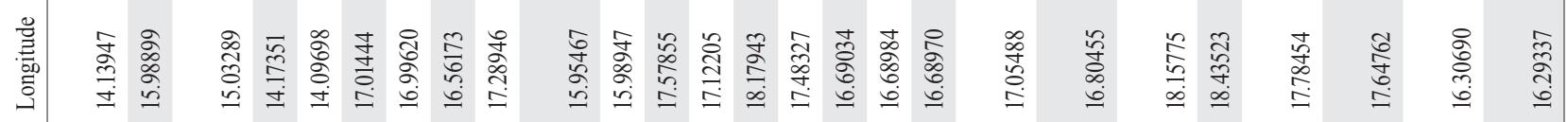

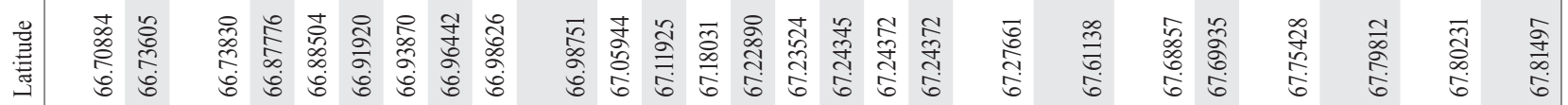

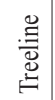

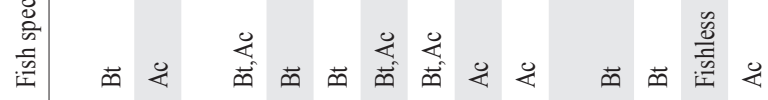

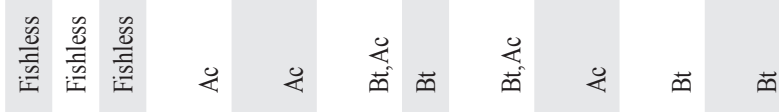
$\stackrel{\Xi}{\stackrel{\Xi}{*}}$

要戈

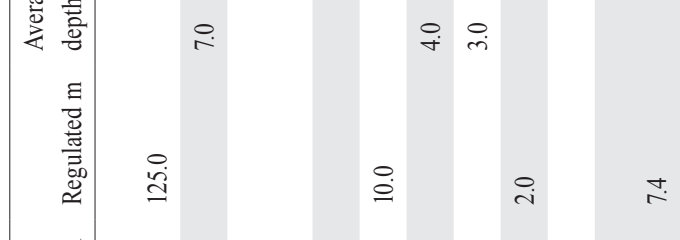

总

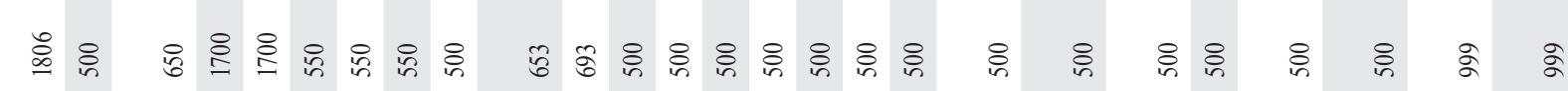
裪

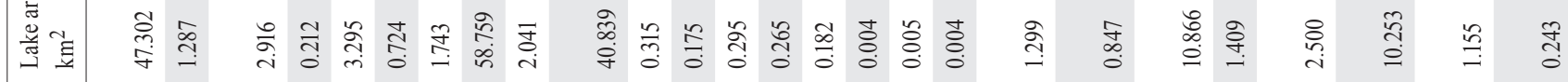

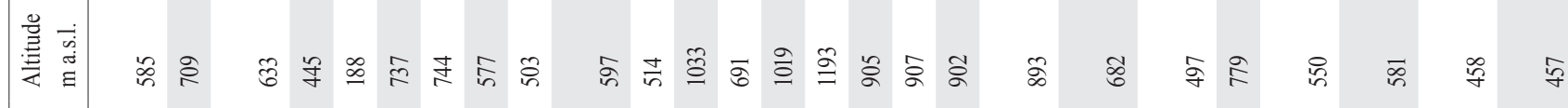

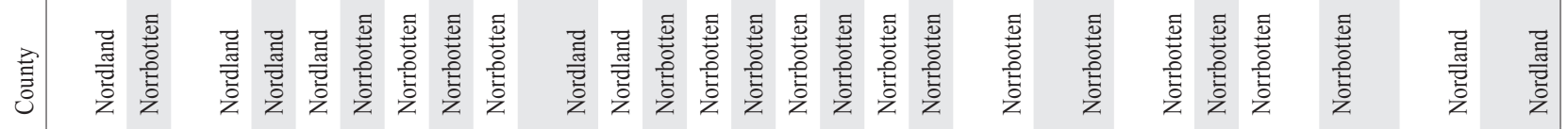

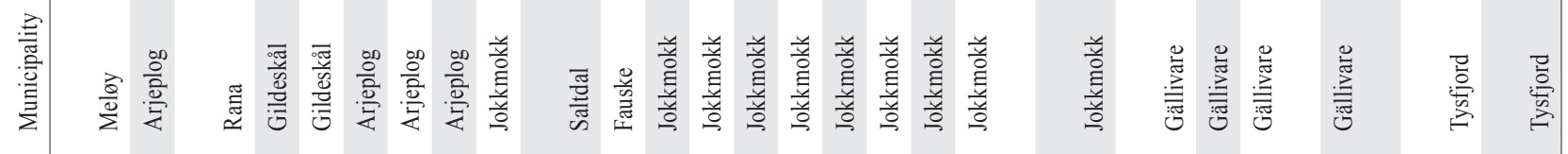

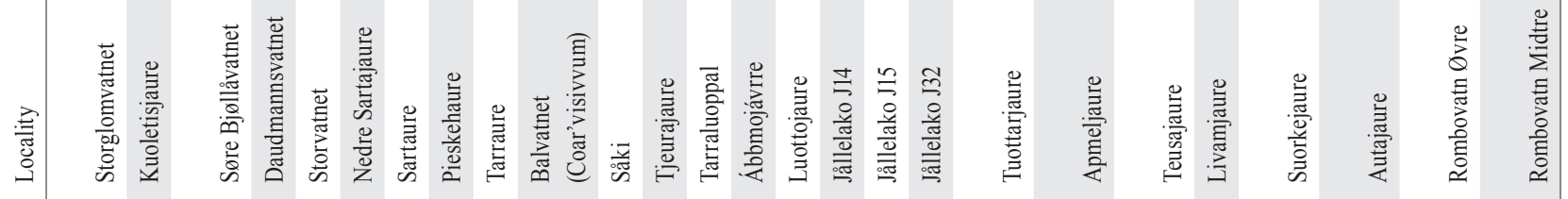

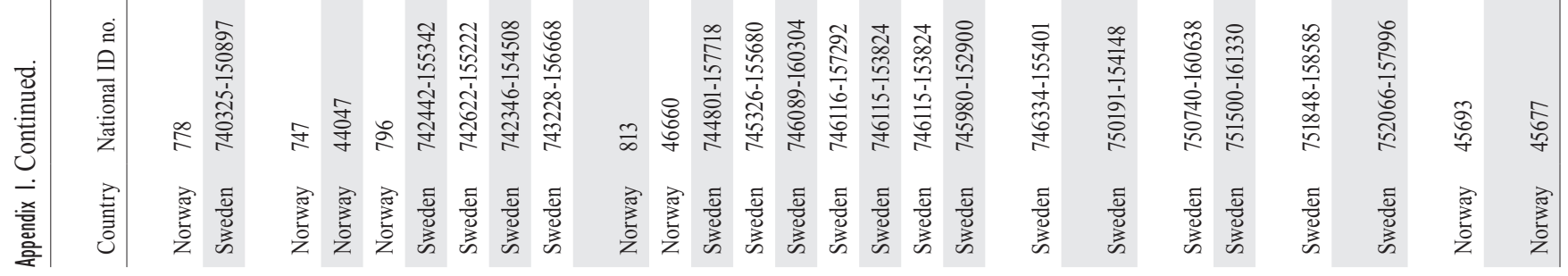




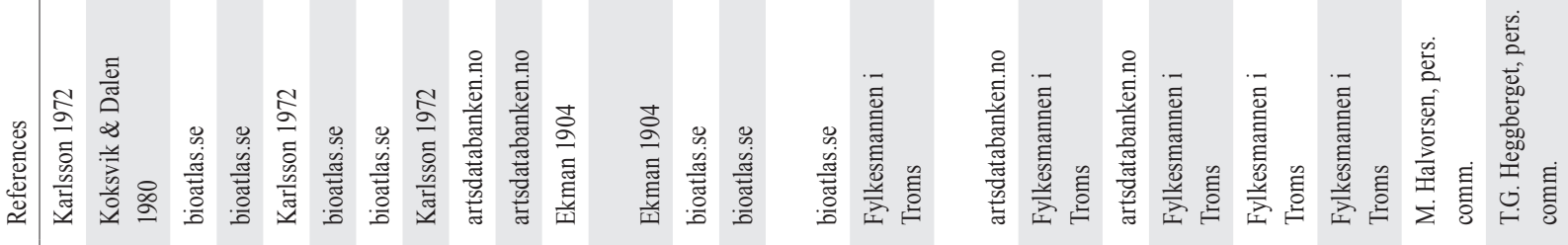

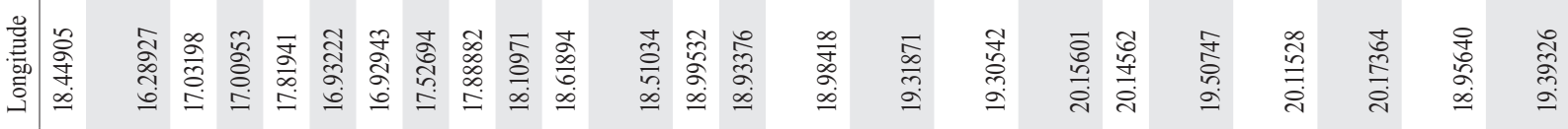

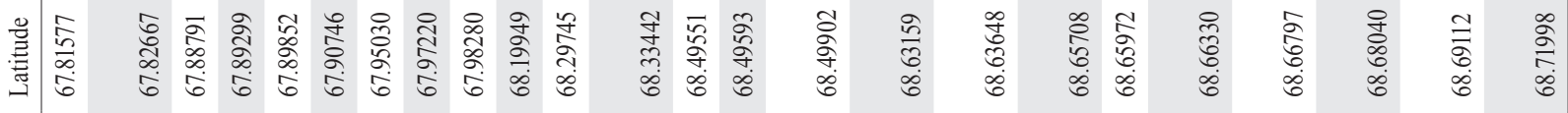

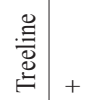

*.:

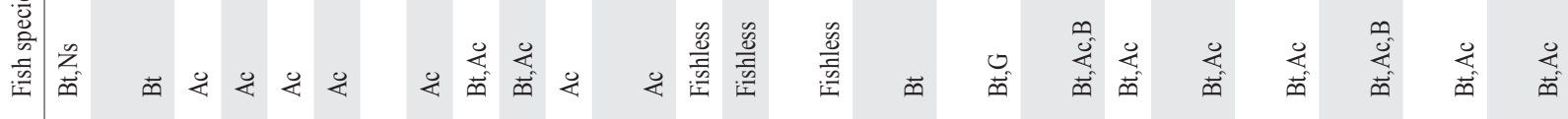

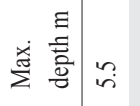

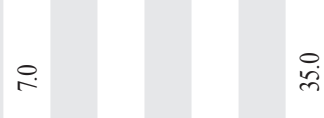

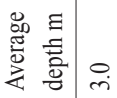

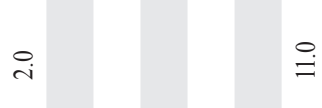

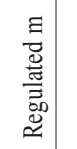

$\stackrel{\circ}{\stackrel{\oplus}{\circ}}$

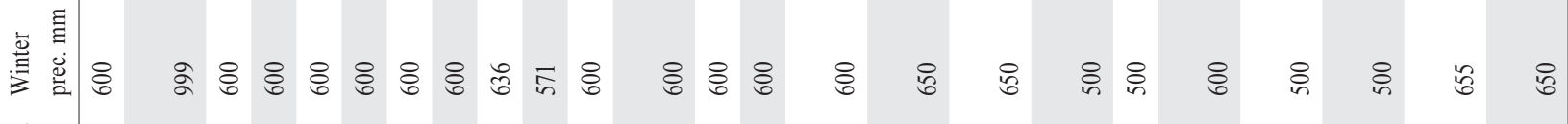

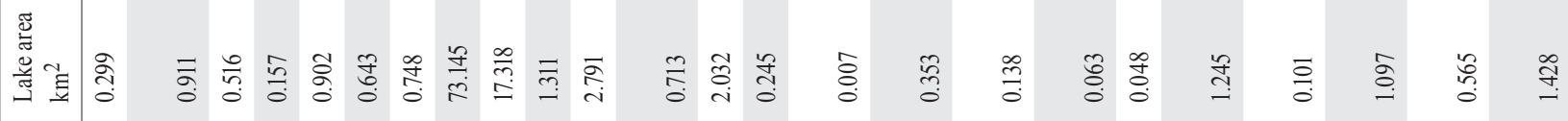

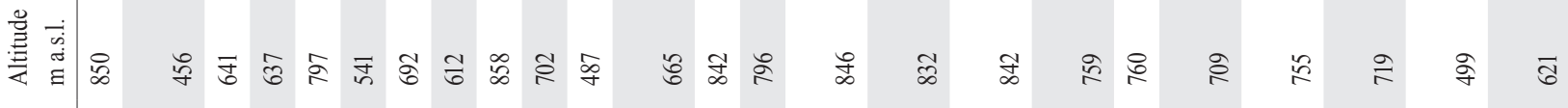

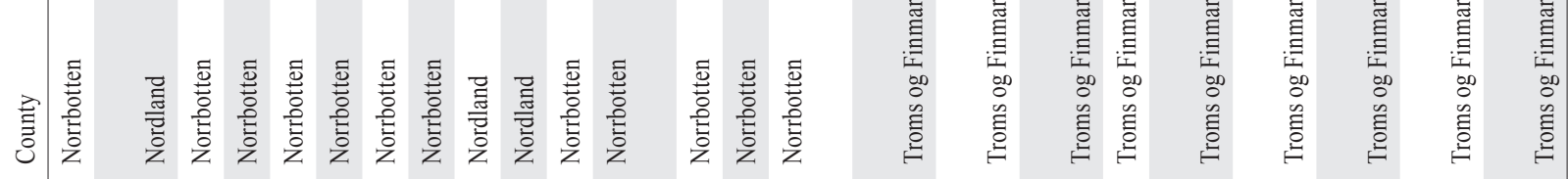

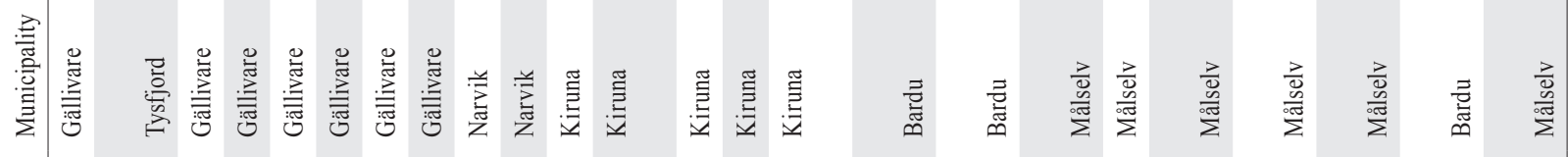

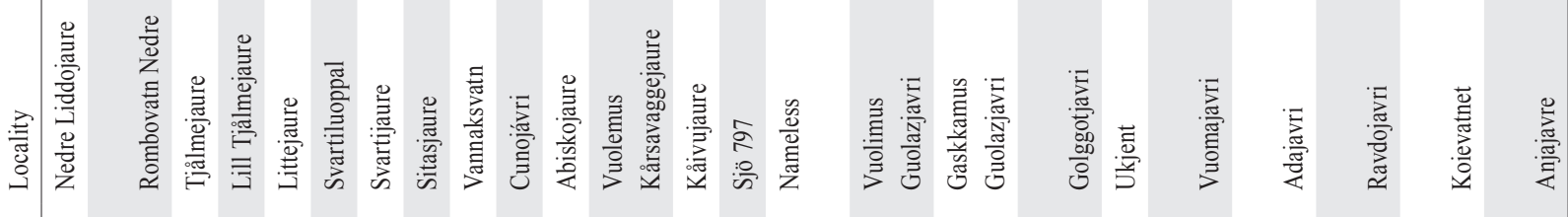

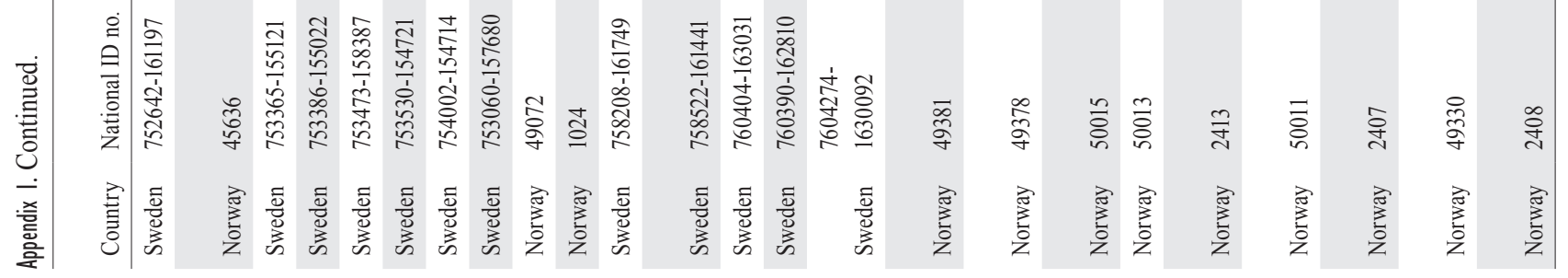




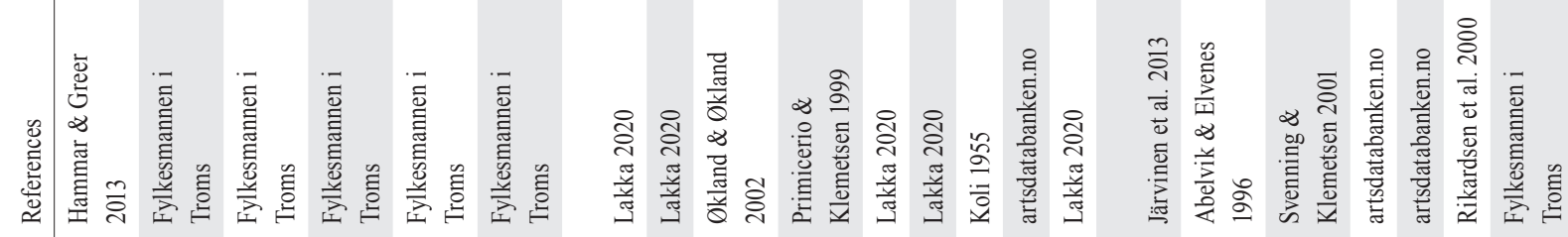

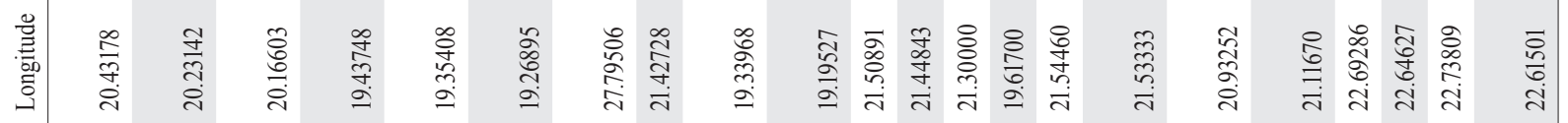

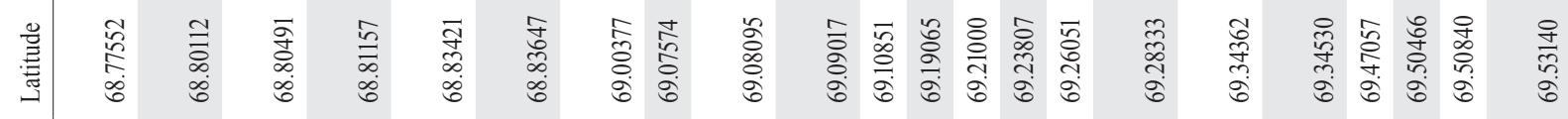
莺

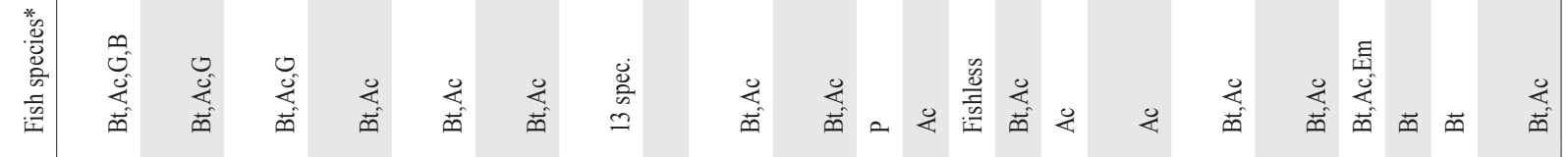

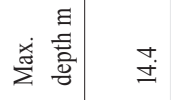

总焉

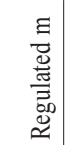

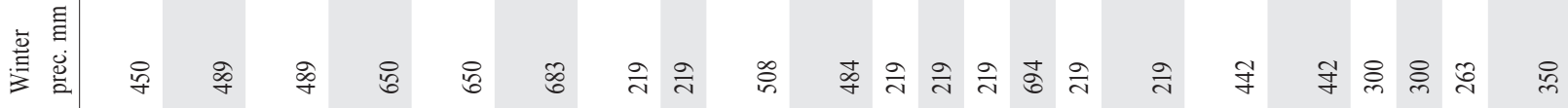

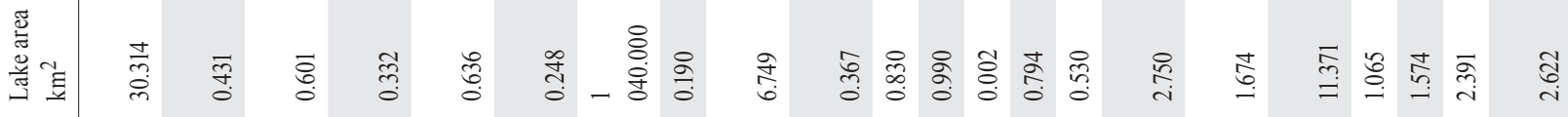

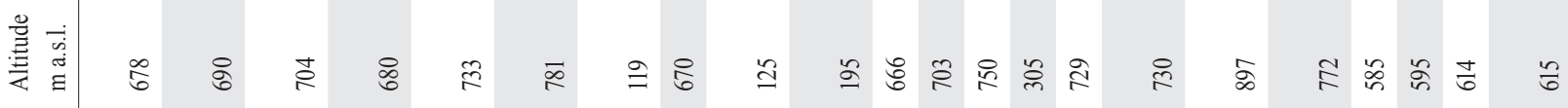

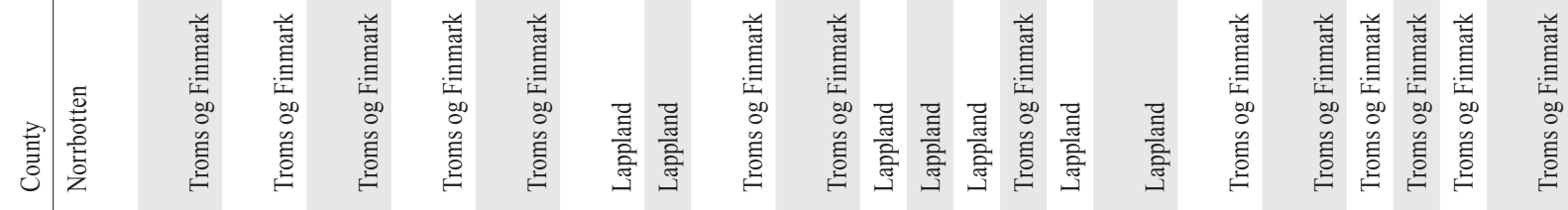

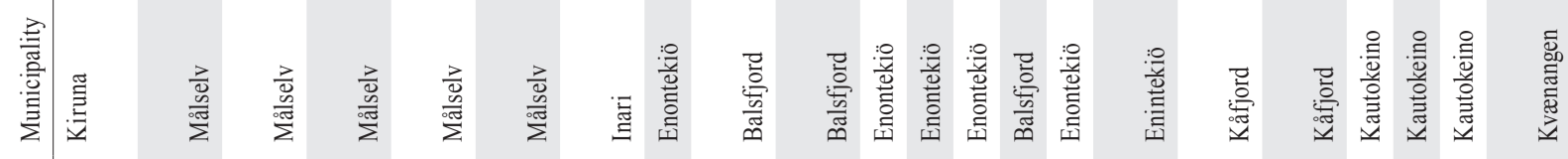

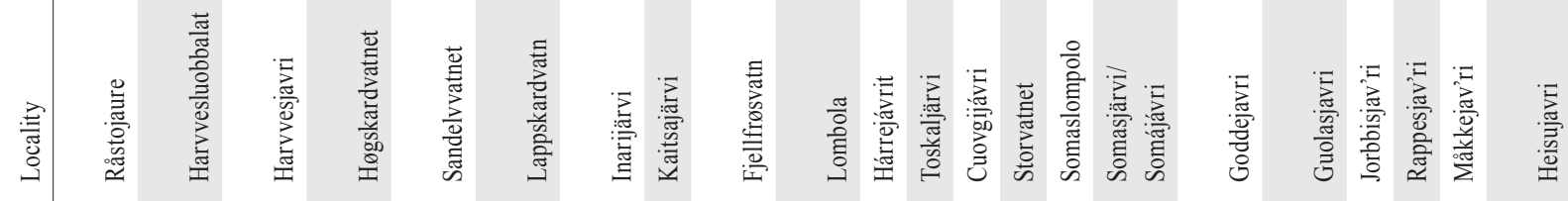

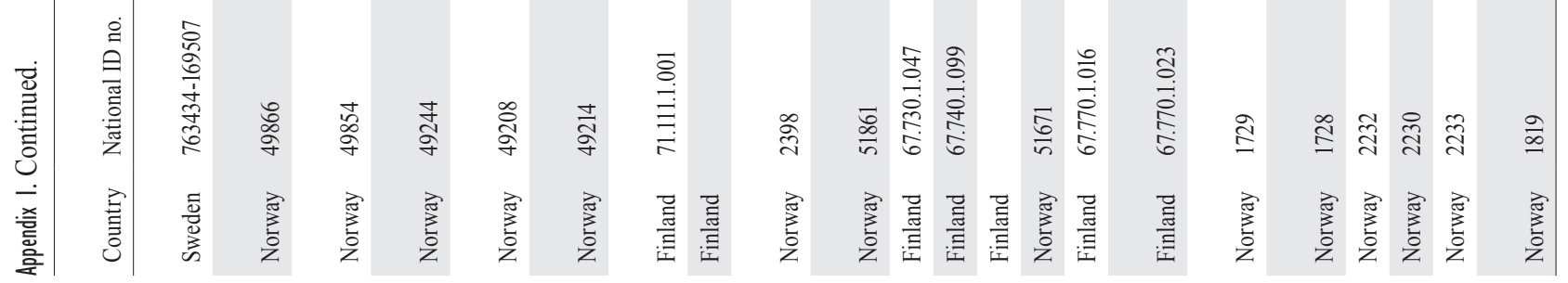




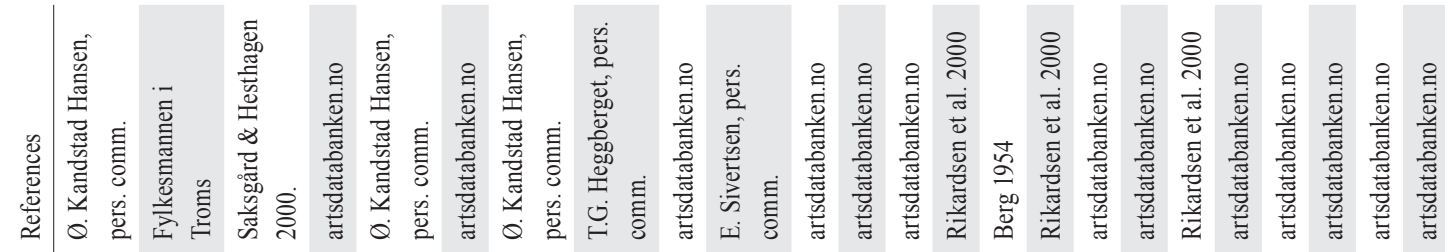

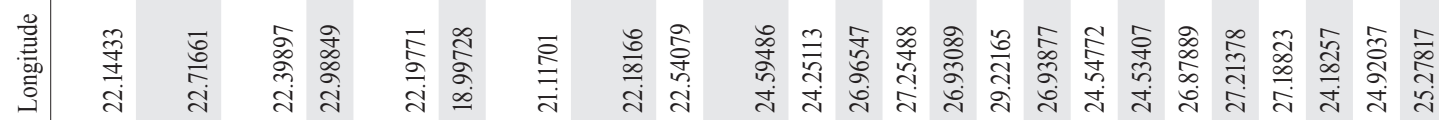

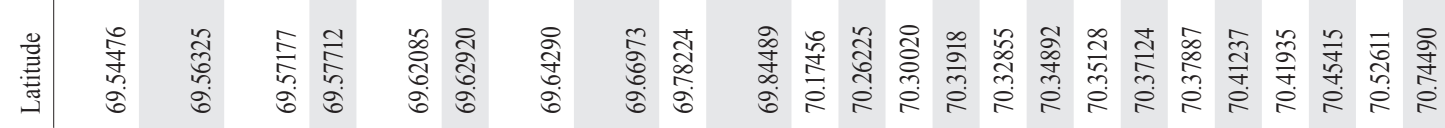

昜

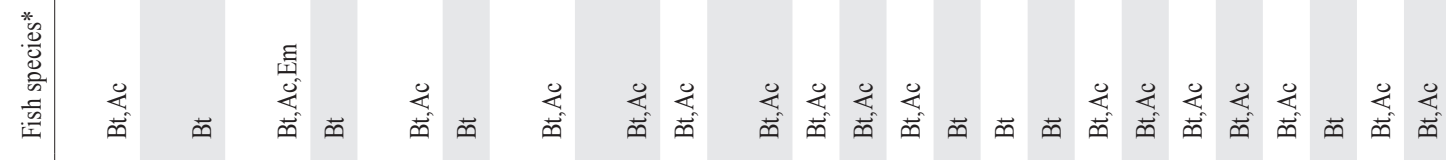

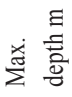

总焉

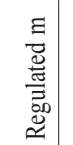

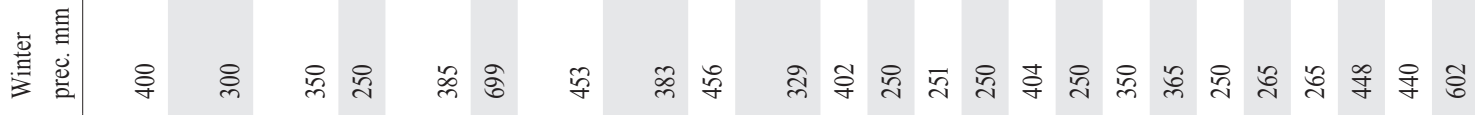

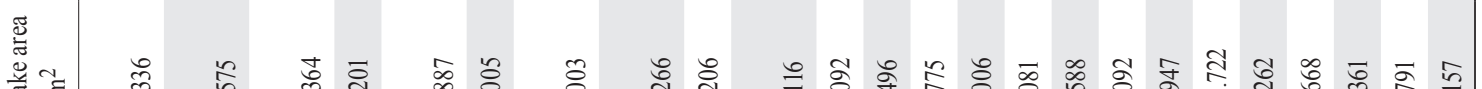

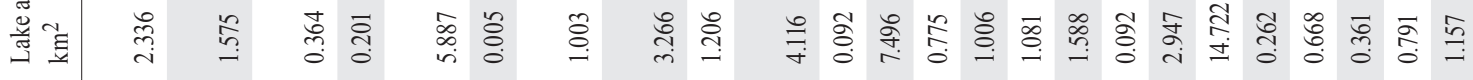

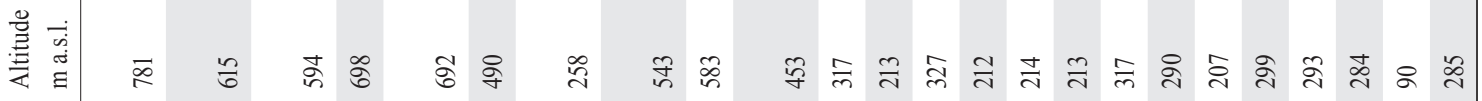

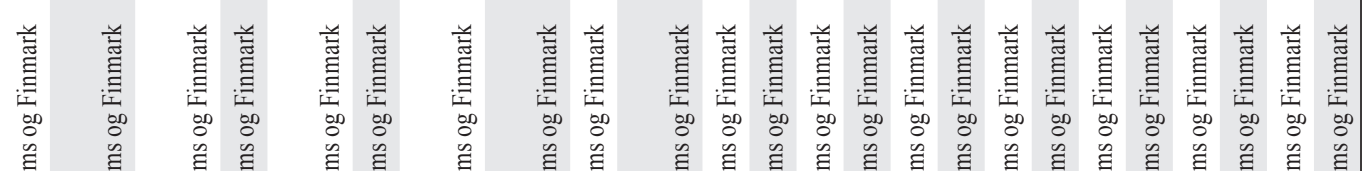

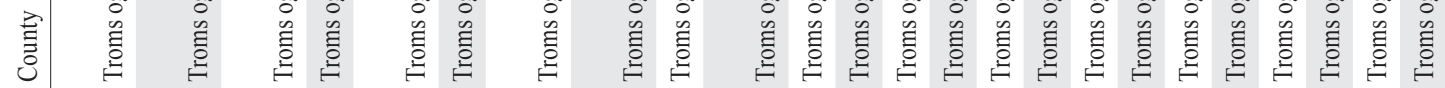

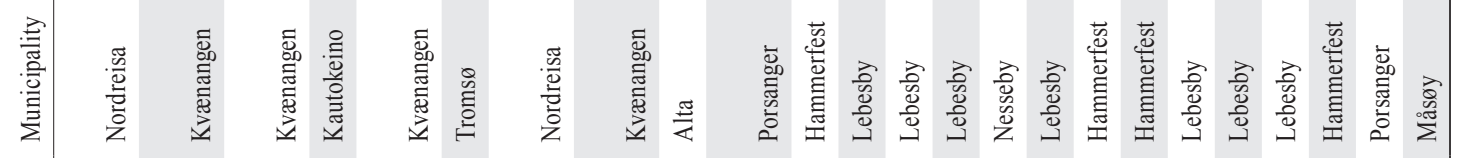

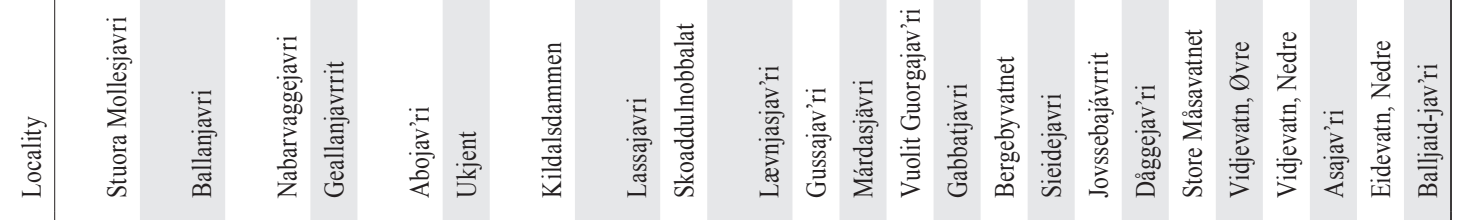

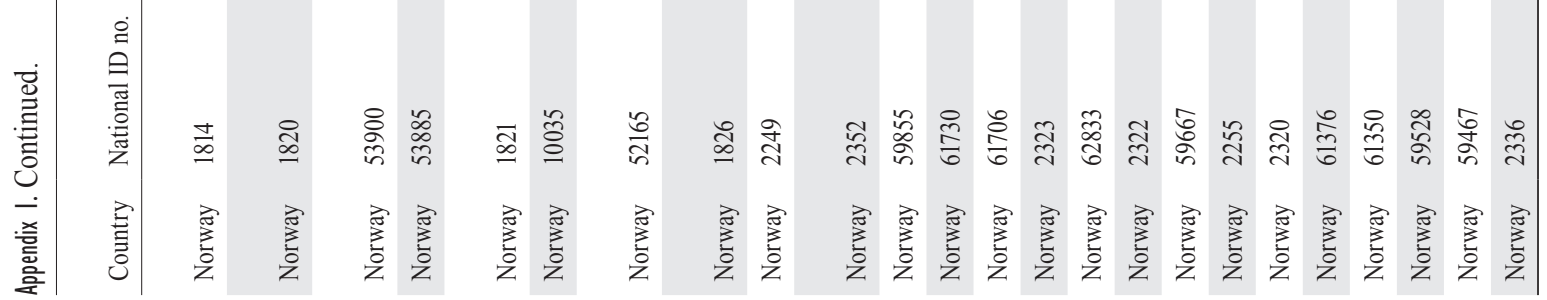

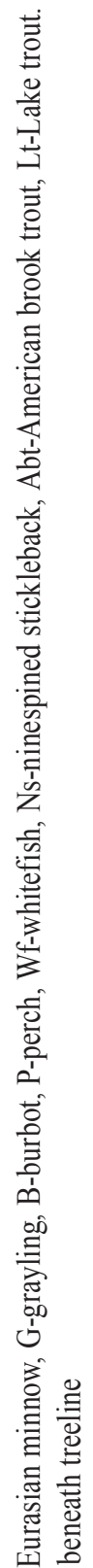

这 $\frac{1}{I}$

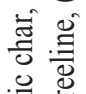

总导

造

言导

突芒

क त 
Appendix I. Continued.

References: In the references, only one reference is given, mainly the first record.

Aass P. 1969. Crustacea, especially Lepidurus arcticus Pallas, as brown trout food in Norwegian mountain reservoirs. Report, Institute of Freshwater Research, Drottningholm 49: 183-201.

Abelvik T, Elvenes R. 1996. Røye (Salvelinus alpinus) i Goddajavri, Gaivuona/Kåjjord. En fiskeribiologisk undersøkelse med forslag til forvaltning. Hovedoppgave ved Høgskolen i Telemark, våren 1995. (In Norwegian).

Amundsen T. 1976. Fiskeribiologiske undersøkelser for Dagalivassdraget 1974-75. Fiskerikonsulenten for Øst-Norge. Rapport Na IV-3.2. 285 pp. (In Norwegian).

Arnekleiv JV, Haug A. 1995. Ferskvannsbiologiske forundersøkelser i Nesåvassdraget og Grøndalselva m.v., Nord-Trøndelag, i forbindelse med planlagt vannkraftutbygging. Rapport, Det Kgl. Norske Videnskabers Selskab, Museet. Zoologisk Serie 1995-1. 67 pp. (In Norwegian).

Arnekleiv JV, Koksvik JI. 1985. Fiskeribiologiske undersøkelser i Raumavassdraget med konsekvensvurderinger av planlagt kraftutbygging. Rapport, Det Kgl. Norske Videnskabers Selskab, Museet. Zoologisk Serie 1985-1. 68 pp. (In Norwegian).

Arnekleiv JV. 1985. Fiskeribiologiske undersøkelser i øvre deler av Stjørdalsvassdraget $\mathrm{i}$ forbindelse med planlagt vannkraftutbygging. Rapport, Det Kgl. Norske Videnskabers Selskab, Museet. Zoologisk Serie 1985-4. 87 pp. (In Norwegian).

Berg M. 1954. New localities of Lepidurus arcticus Pallas in NorthNorway. Astarte 1954 (9): 1-5.

Bergström T. 2003. Inventering av gälbladfotingar i norra Jämtlandsfjällen. Länsstyrelsen i Jämtlands Län, Miljöövervakningsfunktionen, Rapport 03:1. 17 pp. (In Swedish).

Bjørtuft SK, Saltveit SJ. 1993. Fiskeribiologiske undersøkelser i forbindelse med planlagte overføringer til Mår kraftverk i Telemark. Rapport, Laboratoriet for ferskvannsøkologi og innlandsfiske (LFI), Universitetet i Oslo, 140. 33 pp. (In Norwegian).

Blomkvist D. 1995. Bladfotingar som försurningsindikatorer i fjällen. Länsstyrelsen i Norrbottens Län, Luleå. Rapport 3. 53 pp. (In Swedish).

Borgstrøm R. 2003. Midtre Grøndalsvatn 2003. Aurebestandar i Ullensvang statsallmenning, Faktaark nr. 1-2003. 2 pp. (In Norwegian).

Borgstrøm R, Dokk JG, Heun M, Thaulow J. 2010. Aurebestandar i Vierslaområdet. Universitetet for miljø- og biovitenskap, Institutt for naturforvaltning. Fagrapport Fiskeforvaltning i høgfjellet nr. 3-2010. 10 pp. (In Norwegian).

Borgstrøm R, Dokk JG. 2000. Rekruttering til aurebestandar på Vestvidda: Snø, sumartemperatur og interaksjonar innan bestandane er avgjerande faktorar. Norges landbrukshøgskole, Institutt for biologi og naturforvaltning. Fiskerapport nr. 13. 20 pp. (In Norwegian).

Borgstrøm R. 1971. Fiskeribiologiske undersøkelser i Steinbusjøen og Øyangen i Vang i Valdres sommeren 1970. Lab. for Ferskvannsøkologi og Innlandsfiske, Oslo, Rapport nr. 6-1971. 20 pp. (In Norwegian).

Borgstrøm R. 1972. Fisket i Ustevann, Sløtfjord, Nygårdsvann, Bergsmulevann og Finsevann. Forslag til beskatningsmåter. Lab. for Ferskvannsøkologi og Innlandsfiske, Oslo, Rapport nr. 11-1972. 39 pp. (In Norwegian).

Borgstrøm R. 1975. Skjoldkreps, Lepidurus arcticus Pallas i regulerte vann. I. Forekomst av egg i reguleringssonen og klekking av egg. Lab. for Ferskvannsøkologi og Innlandsfiske, Oslo, Rapport nr. 22-1975. 11 pp. (In Norwegian).

Borgstrøm R. 2003a. Midtre Grøndalsvatn 2003. Aurebestandar i Ullensvang statsallmenning, Faktaark nr. 1-2003. 2 pp. (In Norwegian).

Brabrand $\AA$, Heggenes J, Saltveit SJ. 1986. Mistevannføringer i Øystre Slidre-vassdraget: Virkninger på bunndyr, driv og fisk i forbindelse med overføring av vann fra Øyungen til Lomen kraftverk. Rapport, Laboratoriet for ferskvannsøkologi og innlandsfiske (LFI),
Universitetet i Oslo, 78. 58 pp. (In Norwegian).

Brabrand Å, Saltveit SJ. 1978. Fiskeribiologiske undersøkelser i Øyangen, Volbufjorden og Strandefjorden, Øystre Slidre. Rapport, Laboratoriet for ferskvannsøkologi og innlandsfiske (LFI), Universitetet i Oslo, 36. 58 pp. (In Norwegian).

Brinck P, Wingstrand KG. 1951. The mountain fauna of the Virihaure area in Swedish Lapland. II. Special account. Lunds Universitets Årsskrift N.F. Avd. 2, Bd 46, Nr 2. (Kungl. Fysiografiska Sällskapets Handlingar N.F. Bd 61, Nr 2). C.W.K. Gleerup, Lund. 70 pp.

Dahl K. 1915. En studie over grundaatens eller matfloens (Gammarus pulex) biologi og utbredelse i Norge. Særtrykk av Norges Jæger- og Fiskerforenings Tidsskrift 1915. 32 pp. (In Norwegian).

Dahl K. 1917. Studier og forsøk over Ørret og Ørretvand. Kristiania. Det Mallingske Bogtrykkeri. (In Norwegian).

Dahl K. 1932. Influence of water storage of food conditions on trout in Lake Paalsbufjord. Skrifter utgitt av Det Norske Videnskaps-Akademi i Oslo. I. Mat.-Naturv. Klasse. 1931. No. 4.53 pp.

Eidfjord fjellstyre 1995-2010. Diverse fiskerapporter. www. eidfjordfjellstyre.no (In Norwegian).

Ekman S. 1904. Die Phyllopoden, Cladoceren und freilebenden Copepoden der nord-Schwedischen Hochgebirge. Zoologischen Jahrbüchern 21 Abt. F. Syst. (1), Gustav Fischer, Jena. 170 pp.

Ekman S. 1922. Djurvärldens utbredningshistoria på Skandinaviska Halvön. Bonniers, Stockholm. 614 pp. (In Swedish).

Enerud J, Garnås E. 1988. Fiskeribiologiske undersøkelser i Bergsjø, Ål kommune, Buskerud fylke 1987. Rapport, Fylkesmannen i Buskerud, miljøvernavdelingen, 10. (In Norwegian).

Enerud J, Garnås E. 1992. Fiskeribiologiske undersøkelser i Storevatn, Hemsedal kommune 1991. Rapport, Fylkesmannen i Buskerud, miljøvernavdelingen, 19. (In Norwegian).

Enerud J, Garnås E. 1995. Fiskeribiologiske undersøkelser i Sudndalsfjorden, Hol kommune 1995. Rapport, Fylkesmannen i Buskerud, miljøvernavdelingen. 10. (In Norwegian).

Enerud J, Garnås E. 1995. Fiskeribiologiske undersøkelser i Vatsfjorden, Ål kommune 1995. Rapport, Fylkesmannen i Buskerud, miljøvernavdelingen, 9. (In Norwegian).

Enerud J. 1981. Fiskeribiologiske undersøkelser i Fundin og Einunna. Fiskerikonsulenten i Øst-Norge. Rapport. 36 pp. (In Norwegian).

Fjellheim A, Raddum GG. 2007. Nygård pumpekraftverk. Prøvefiske i Askjelldalsvatnet 2006. Kontrollfiske i Steinslandsvatnet og Stølsvatnet. Laboratoriet for ferskvannsøkologi og innlandsfiske LFI/ UNIFOB, Universitetet i Bergen. Rapport nr. 139-2007. 26 pp. (In Norwegian).

Fjellheim A, Tysse $\AA$, Bjerknes V, Wright RF. 2002. Finprikkauren på Hardangervidda. DN-utredning 2002-1. 58 pp. (In Norwegian).

Fürst, M. 1981. Results of introductions of new fish food organisms into Swedish lakes. Report, Institute of Freshwater Research, Drottningholm 59: 33-47.

Fängstam H. 1998. Njereujaure. Inventering sommaren 1997. Rapport, Länsstyrelsen i Västerbottens län, 2.22 pp. (In Swedish).

Fängstam H. 1999a. Guoletsjaure, Njarkajauretjärn 1, Moskosjauretjärn 1, Skiträsktjärn 1, Östra Gapsjaure och Skiermotjåltetjärnen. Inventering sommaren 1998. Rapport, Länsstyrelsen i Västerbottens län, 5. 33 pp. (In Swedish).

Fängstam H. 1999b. Nairekenområdets tjärnar. Inventering sommaren 1998. Rapport, Länsstyrelsen i Västerbottens län, 6. 26 pp. (In Swedish).

Gjøstein G, Hauge TA. 1994. Vandring hjå allopatrisk aure, Salmo trutta L. i ulikt tette bestandar, eit radiotelemetristudium i tre vatn på Hardangervidda. Norges landbrukshøgskole, Institutt for biologi og naturforvaltning. MSc thesis. $32 \mathrm{pp}$. (In Norwegian).

Gulbrandsen TR, Johannessen M, Kildal T, Kjellsen A, Kulsvehagen E. 1986. Forsuringssituasjonen på Hardangervidda - kjemisk vannkvalitet og fiskestatus 1983-1985. Rapport, Fylkesmannen i Telemark, miljøvernavdelingen, 2. 35 pp. (In Norwegian).

Gunnerød TG, Klemetsen CE, Møkkelgjerd PI. 1975. Fiskeribiologiske 


\section{Appendix I. Continued.}

undersøkelser i Begna- og Åbjøravassdragene i 1973. (Vangsmjøsa, Helin, Flyvatn, Storevatn, Tisleifjorden og Ølsjøen). Direktoratet for vilt og ferskvannsfisk. Reguleringsundersøkelsene. Rapport 2-1975. $27 \mathrm{pp}$.

Gydemo R. 1979. Populationsgenetisk undersökning av röding i Västerbottens län Del 2. Fiskenämnden och Lantbruksnämnden, Västerbottens län, Umeå. (In Swedish.)

Halvorsen G, Gullestad N. 1976. Freshwater Crustracea in some areas of Svalbard. Arch. Hydrobiol. 78(3): 383-395.

Halvorsen G. 1973. Crustacea from the High Mountain Area Hardangervidda, South Norway. Rapport fra Høyfjellsøkologisk Forskningssenter, Finse, Norge. 1973 (3). 17 pp.

Hammar J, Greer RB. 2013. The Arctic char of Lake Rostujávri - a completion and climate change induced enigmatic resource for anglers. Aqua Reports 2013:14, Swedish University of Agricultural Sciences, Drottningholm. 65 pp. (In Swedish with an English Summary).

Hammar J. 1978. Resultat av provtrålning efter Pallasea quadrispinosa Övre Umeälven. PM 1978.12.08. Sötvattenslaboratoriet, Drottningholm. 3 pp. (In Swedish).

Hansen J-H, Stubsjøen I. 1984. Savalen. Virkninger av vannstandssenkninger med 3.0/4.7 m på bunndyr og fisk. Norges landbrukshøgskole, Institutt for biologi og naturforvaltning. MSc thesis. 106 pp. (In Norwegian).

Hedlund M. 2000. Arevattnet och dess öring. Länsstyrelsen i Västerbottens län. Rapport Fiske (6). 16 pp. (In Swedish).

Hellen BA, Brekke E, Johnsen GH. 2001. Prøvefiske i 26 innsjøer i Hordaland høsten 1999. Rapport, Rådgivende biologer AS, 424. 164 pp. (In Norwegian).

Hesthagen T, Gunnerød TG. 1981. Fiskeribiologiske undersøkelser i Vinstravassdraget, Oppland sommeren 1980. Direktoratet for vilt og ferskvannsfisk. Reguleringsundersøkelsene. Rapport 6-1981. 43 pp. (In Norwegian).

Huitfeldt-Kaas, H. 1916. Om indsættelse av nye sorter fiskeaat vore fiskevand. Særtrykk av Fiskeriinspektørens indberetning om ferskvannsfiskeriene for 1912-1913. Kristiania 1916. (In Norwegian)

Hvidsten NA, Johnsen BO. 1976. Fiskeribiologiske undersøkelser i Nordre og Søndre Bjøllåvatn, Bjøllåga, Storrmdalsåga,Tespa og Øvre Ranaelva, sommeren 1975. Direktoratet for vilt og ferskvannsfisk, Reguleringsundersøkelsene i Nordland, 4-1976. 41 pp. (In Norwegian).

Jensen JW. 1973. Fiskeribiologiske undersøkelser i Åbjøravassdraget 1971 og 1972. Det Kongelige Norske Videnskabers Selskab, Museet, Universitetet i Trondheim. Rapport, Zoologisk serie 1973-17. 24 pp. (In Norwegian).

Jensen JW. 1974. En hydrografisk og biologisk inventering av Åbjøravassdraget, Bindal. Det Kongelige Norske Videnskabers Selskab, Museet, Universitetet i Trondheim. Rapport, Zoologisk serie 1974-4. 30 pp. (In Norwegian).

Jensen JW. 1975. Fisket $i$ en del av elvene og vatnene som berøres av Eidfjord-Nord utbyggingen. Det Kongelige Norske Videnskabers Selskab, Museet, Universitetet i Trondheim. Rapport, Zoologisk serie 1975-15. 37pp. (In Norwegian).

Järvinen A, Lakka H-K, Sujala M. 2014. The Arctic tadpole shrimp, a living fossil in mountain waters, again found in Finland. Nature Scientist 1-2014:19-24. (In Finnish).

Karlsson R. 1971. Verksamheten ovan odlingsgränsen år 1970. II. Fiskevatteninventering i Laisälvsområdet, fiskevårdsåtgärder och kontroll av tidigare utförda fiskevårdsåtgärder. 82 pp. (In Swedish).

Karlsson R. 1972. Fynd av Lepidurus arcticus i Norrbottens fjällområde. Unpublished manuscript with comments by P. Aass and N.-A. Nilsson. Fiskeriintendenten i Luleå. $10 \mathrm{pp}$. (In Swedish).

Kildal T, Kaasa H. 1973. Rapport fra prøvefisket i Briskevatn, Mellomhølen og Mørevatn. Rapport. 28 pp. (In Norwegian).

Kildal T, Kaasa H. 1975. Rapport fra prøvefisket i Honserud, Vollevatn og Tosketjønn. Rapport. 33 pp. (In Norwegian).

Kildal T. 1980. Fiskeribiologiske undersøkelser i Kvenna 1978
Fiskerikonsulenten i Øst-Norge. Rapport. 41 pp. (In Norwegian).

Kildal T. 1981. Fiskeribiologiske undersøkelser i Skvettavassdraget 1980. Fiskerikonsulenten i Øst-Norge. Rapport nr. 17-1981. 33 pp. (In Norwegian).

Kildal T. 1982a. Fiskeribiologiske undersøkelser i Kvenna og Bjønna 1978. Fiskerikonsulenten i Øst-Norge. Rapport nr. 1-1982. 45 pp. (In Norwegian).

Kildal T. 1982b. Fiskeribiologiske undersøkelser i Kvenna 1979. Rapport frå brukerundersøkinga i Kvenna 1979. Fiskerikonsulenten i ØstNorge. Rapport nr. 2-1982. 36 pp. (In Norwegian).

Klausen TR. 2012. Population regulation in the tadpole shrimp Lepidurus arcticus. MSc-thesis, Norwegian University of Science and Technology, Department of Biology. $25 \mathrm{pp}$.

Koksvik JA, Arnekleiv JV. 2001. Fiskeribiologiske undersøkelser i Fjergen sju år etter siste tilleggsregulering. Rapport, Det Kgl. Norske Videnskabers Selskab, Museet. Zoologisk Serie 1. 27 pp. (In Norwegian).

Koksvik JA, Dalen T. 1980. Ferskvannsbiologiske og hydrografiske undersøkelser i Hellemoområdet, Tysfjord kommune. Rapport, Det Kgl. Norske Videnskabers Selskab, Museet. Zoologisk Serie 10. 57 pp. (In Norwegian).

Koksvik JA, Nøst T. 1981. Gaulavassdraget i Sør-Trøndelag og Hedmark fylker. Ferskvannsbiologiske undersøkelser i forbindelse med midlertidig vern. Rapport, Det Kgl. Norske Videnskabers Selskab, Museet. Zoologisk Serie 24. 96 pp. (In Norwegian).

Koksvik JI. 1976.Hydrografi og evertebratfauna i Vefsnavassdraget 1974. Rapport, Det Kgl. Norske Videnskabers Selskab, Museet. Zoologisk Serie $4.96 \mathrm{pp}$.

Koli L. 1957. Beiträge zur Kenntnis der Euphyllopodenfauna Finnlands. Archiv Societatis Zoologicae Botanicae Fennica 'Vanamo'. 11:2 (Helsinki): 108-111.

Korsen I, Gjøvik JA. 1977. Undersøkelser i 10-års vernede vassdrag. Årsrapport 1977. Drivavassdraget, Todalsvassdraget. Direktoratet for vilt og ferskvannsfisk. Fiskerikonsulenten i Midt-Norge. Rapport. 114 pp. (In Norwegian)

Lakka H-K. 2020. Environmental Changes in Arctic Freshwaters. The Response of Indicator Species to Global Warming and Acidification in the Arctic. PhD-Thesis, University of Jyväskylä, 2020: 51 pp.

Lehmann GB, Wiers T. 2004. Fiskeressursprosjektet i Hordaland: Fiskeundersøkelser i regulerte innsiøer og vassdrag i Hordaland, juli 2002 - april 2003. Rapport, Fylkesmannen i Hordaland, miljøvernavdelingen. 1.79 pp. (In Norwegian).

Lien L. 1978. The energy budget of the brown trout population of Øvre Heimdalsvatn. Holarct. Ecol. 1: 279-300.

Lier-Hansen, S. 1980. Prøvefiske i Gøyst/ Strengevann. Rapport. (In Norwegian).

Lindås OR. 1993. Etterundersøkelser av regulerte elver og magasineri Øvre Otra, Aust-Agder, 1991. Rapport, Laboratoriet for ferskvannsøkologi og innlandsfiske (LFI), Universitetet i Oslo, 146.56 pp. (In Norwegian). Lindås OR. 1994. Etterundersøkelser I magasiner og regulerte elver i Øvre Otra, Aust-Agder 1993. Rapport, Laboratoriet for ferskvannsøkologi og innlandsfiske (LFI), Universitetet i Oslo, 152. 84 pp. (In Norwegian).

Lingdell P-E, Engblom E. 1990. Kräftdjur som miljöövervakare. Statens Naturvårdsverk PM 3811. 119 pp. (In Swedish).

Lingdell, P.-E. \& Engblom, E. 1990. Kräftdjur som miljöövervakare. Statens Naturvårdsverk PM 3811. 119 p. (In Swedish).

Løkensgard T, Rosseland L. 1963. Reguleringsoverføringer i Uvdalsvassdraget. Virkninger på fisket. Stensil. (In Norwegian).

Løkensgard T. 1975. Fiskeribiologiske undersøkelser av Hettefjorden, Eidsjåen og Kalven. Fiskerikonsulenten i Øst-Norge. Rapport, 7 pp. (In Norwegian)

Madsen J-P. 1970-1988. Diverse fiskeriundersøkelser på Hardangervidda 1970-1988. Hordaland landbruksselskap/ Fylkesmannen i Hordaland. Diverse befaringsrapporter. (Oppbevares hos Fylkesmannen i Hordaland. (In Norwegian).

Mollerud A. 1971. Rapport fra fiskevannsundersøkelsene i Skjerjavatnet, 


\section{Appendix I. Continued.}

Hol, sommeren 1970. Buskerud Landbruksselskap. Rapport. 9 pp. (In Norwegian).

Muniz IP. 1968. Rapport fra de fiskeribiologiske undersøkelser i Odda og Ullensvang statsalmenninger sommeren 1967. Konsulenten for ferskvannsfisket i Vest-Norge. Rapport. 77 pp. (In Norwegian).

Muniz IP. 1969. Rapport fra de fiskeribiologiske undersøkelser i Eidfjord statsalmenning sommeren 1968. Konsulenten for ferskvannsfisket $\mathrm{i}$ Vest-Norge. Rapport. 72 pp. (In Norwegian).

Myrvang R, Slettebø D. 2013. Historiske aurebestander (Salmo trutta) på Sentralvidda - Endringer i bestandsstruktur og livshistorietrekk som følge av endring i beskatning og variasjon i klimaforhold. Universitetet for miljø og biovitenskap, Institutt for naturforvaltning. Master thesis. 66 pp. (In Norwegian).

Nilsson N-A, Filipsson O. 1971. Characteristics of two discrete populations of Arctic char (Salvelinus alpinus L.) in a north Swedish lake. Report: Institute of Freshwater Research, Drottningholm, 51: 90-108.

Nilsson N-A. 1963. Interaction between trout and char in Scandinavia. Transactions of the American Fisheries Society 92(3): 276-285.

Nilsson N-A. 1965. Food segregation between salmonoid species in North Sweden. Report, Institute of Freshwater Research, Drottningholm, 46: 58-78.

NOU 1974. Norges offentlige utredninger. Hardangervidda. Natur Kulturhistorie - Samfunnsliv. Miljøverndepartementet. NOU 1974:30 B. 352 pp. (In Norwegian).

Nøst T, Koksvik JI. 1980. Ferskvannsbiologiske og hydrografiske undersøkelser i Nesåvassdraget 1977-1978. Rapport, Det Kgl. Norske Videnskabers Selskab, Museet. Zoologisk Serie 8. 52 pp. (In Norwegian).

Nøst T. 1981. Ferskvannsbiologiske og hydrografiske undersøkelser i Drivavassdraget 1979-80. Rapport, Det Kgl. Norske Videnskabers Selskab, Museet. Zoologisk Serie 10. 77 pp. (In Norwegian).

Primicerio R, Klemetsen A. 1999. Zooplankton seasonal dynamics in the neighbouring lakes Takvatn and Lombola (Northern Norway). Hydrobiologia 411:19-29.

Qvenild T. 1978. Fiskeribiologiske undersøkelser Uste - Nes, Hol kommune, 1976. Fiskerikonsulenten i Øst-Norge. Rapport. 44 pp. (In Norwegian).

Raddum GG, Fjellheim A. 1994, Fiskeribiologiske undersøkelser i Vassøyane - Raudbergvatn. Rapport, Laboratoriet for ferskvannsøkologi og innlandsfiske (LFI), Universitetet i Bergen, 83. 7 pp. (In Norwegian).

Rikardsen AH, Johansen M, Svenning MA. 2000. Fiskeribiologiske etterundersøkelser i Adamselv reguleringen 1999. Norsk institutt for naturforskning. Oppdragsmelding nr. 639. 34 pp. (In Norwegian with an English summary).

Rognerud S, Qvenild T, Fjeld E. 2005. Hardangerviddaprosjektet. Resultater fra undersøkelsen i 2004. NIVA Rapport L.NR. 5025-2005. 35 pp. (In Norwegian).

Runnström S, Määr A. 1950. Lepidurus arcticus PALLAS in Indalsälven and Faxälven watersystems, Sweden and Norway. Report, Institute of Freshwater Research, Drottningholm, 31: 147-150.

Saksgård R, Hesthagen T. 2000. Vannbiologisk overvåking. Fisk. Statlig program for overvåking. Årsrapport 1999. Statens forurensningstilsyn (SFT) nr. 804/00. (TA-1748/2000).

Saltveit SJ. 1985. Sundheimselva kraftverk, Vestre Slidre, Oppland. En vurdering av de fiskeribiologiske forhold og virkninger på fisk og næringsdyr i berørte innsjøer og elvestrekninger. Rapport, Laboratoriet for ferskvannsøkologi og innlandsfiske (LFI), Universitetet i Oslo, 74. 79 pp. (In Norwegian).

Sars GO. 1864.Beretning om en i sommeren 1863 foretagen zoologisk Reise i Christiania og Throndhjems Stifter. Nytt Mag. Naturvid. 13:225-260. (In Norwegian).

Sivertsen E. 1962. Namsvatn - Fiskeribiologiske undersøkelser etter at vannet var regulert. Årbok, Det Kgl. Norske Videnskabers Selskab, Museet: 37-66. (In Norwegian).
Sivertsen B. 1973. The bottom fauna of Lake Huddingsvatn, based on quantitative sampling. Norw. J. Zool. 21: 305-321.

Sjursen AD, Arnekleiv JV, Kjærstad G, Rønning L. 2010. Fiskeribiologiske undersøkelser i Fjergen 2009. Rapport, Det Kgl. Norske Videnskabers Selskab, Museet. Zoologisk Serie 3. 44 pp.

Solhøi H. 1995. Fiskeressurser i regulerte vassdrag i Telemark. Rapport, Fylkesmannen i Telemark, Miljøvernavdelinga. 178 pp. (In Norwegian).

Svenning M, Klemetsen A. 2001. Overbefolka røyevatn i Nord-Norge (ORN). Norsk institutt for naturforskning. Sluttrapport fra ORNprosjektet: 21-47. (In Norwegian).

Sømme ID. 1931. Nærings- og gytevandring hos ørreten på Hardangervidda. Norges Jæger- og Fiskerforenings Tidsskrift: 381402. (In Norwegian).

Sømme ID. 1936. Fortsatte undersøkelser over ørretens vandringer. Norges Jæger- og Fiskerforenings Tidsskrift: 296-304, 338-349. (In Norwegian).

Sømme S. 1934. Contributions to the biology of Norwegian fish food animals I. Lepiduruas arcticus Pallas 1793. Avhandlinger utgitt av det Norske Videnskaps Akademi i Oslo. I. Matem.-Naturvid. Klasse 1934. No 6: 1-36.

Tysse Å, Garnås E. 1994. Fiskeribiologiske undersøkjingar i Halne, Heinog Krækkjavassdraget i Hol og Nore og Uvdal kommuner 1992/ 93. Rapport, Fylkesmannen i Buskerud, miljøvernavdelingen, 16. 33 pp. (In Norwegian).

Vasshaug Ø. 1970. Fiskeribiologiske undersøkelser 1967-69. Fiskerikonsulenten for Vest-Norge. Rapport. 67 pp. (In Norwegian).

Walseng B, Halvorsen G, Schartau AKL. 1994. Ferskvannsbiologiske undersøkelser i Kvenna, 1978. NINA Oppdragsmelding nr. 321-1994. 33 pp. (In Norwegian).

Walseng B, Raddum G, Saksgård R, Schartau AKL. 1996. Ferskvannsbiologiske undersøkelser i Kvenna 1995, med fokus på indikatorarter som redskap i forsuringsovervåkingen. NINA Oppdragsmelding $433.36 \mathrm{pp}$. (In Norwegian).

Wiers T, Hylland S. 2001. Prøvefiske i Ullensvang, Hardangervidda 2000. Veivatn, Bersarvikvatnet, Holmavatnet, Austmannavatnet, Hanasteinsvatnet, Tresnutevatnet og Skinnhovdavatnet. Naturoppdrag. Rapport nr. 32-2001. 42 pp. (In Norwegian).

Wiers T, Hylland S. 2002. Prøvefiske i Ullensvang, Hardangervidda 2001. Langavatnet, Vasslivatnet, Reinavatnet, Busetevatnet, Vetlavatnet og Vatnasetvatnet. Naturoppdrag. Rapport nr. 35-2002. 30 pp. (In Norwegian).

Økland J, Økland KA. 2002. Funn av skjoldkreps og tusenbeinskreps i Norge - sluttrapport. Biologisk institutt, Universitetet i Oslo. 16 pp. 


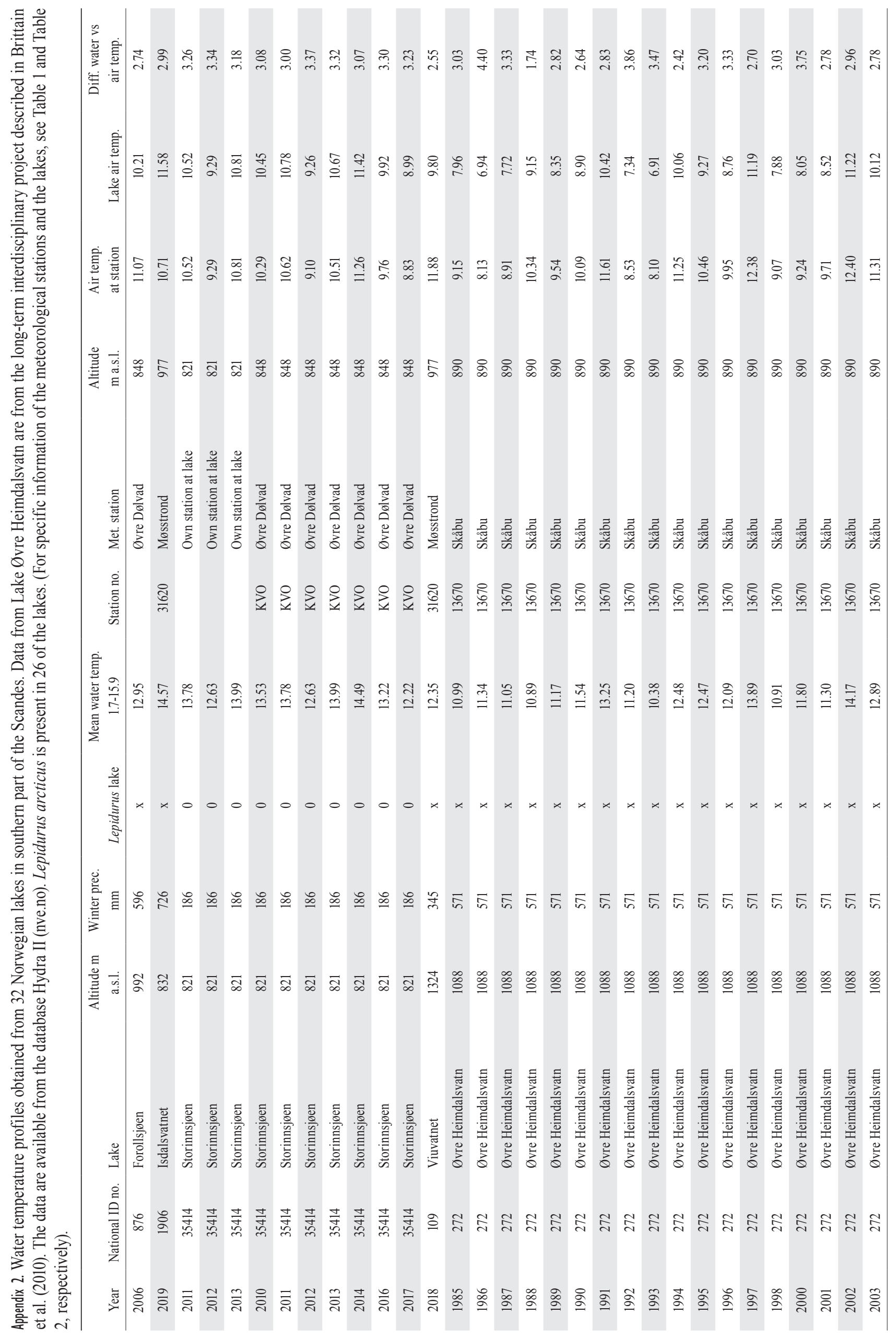




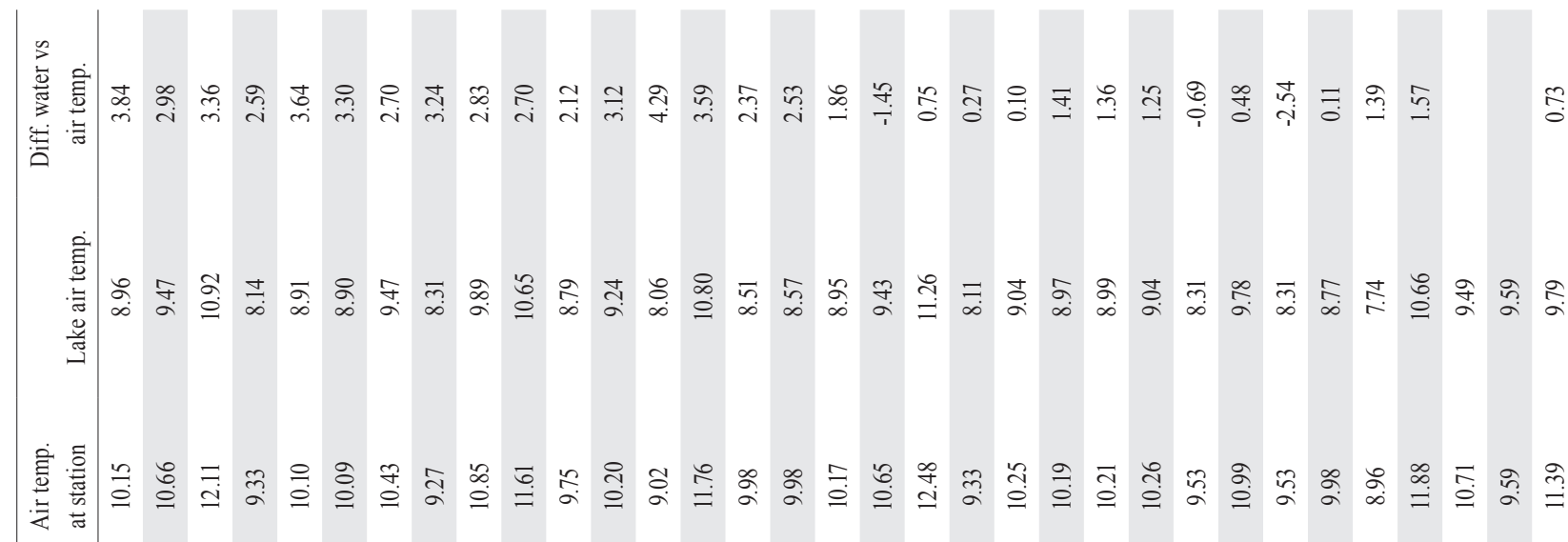

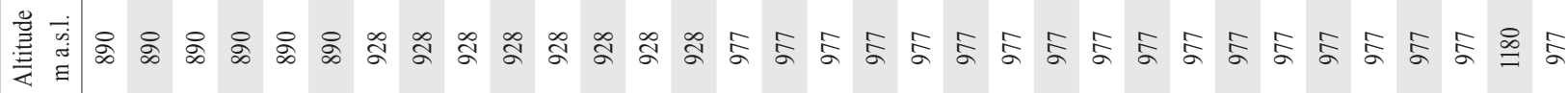

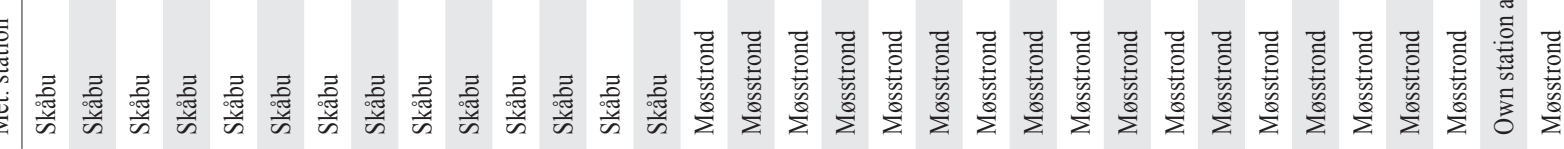

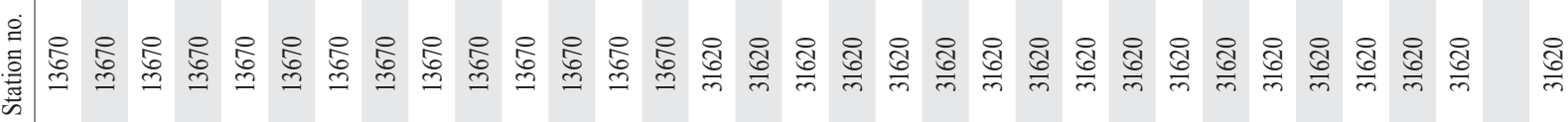

言

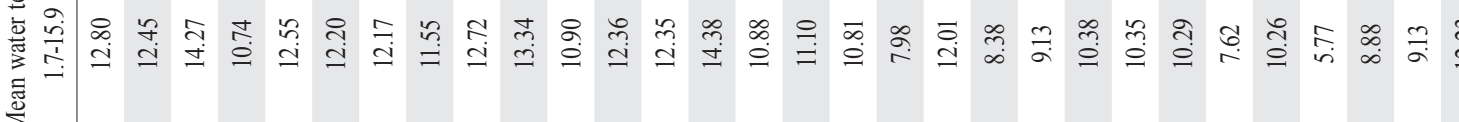
宽

흔

害

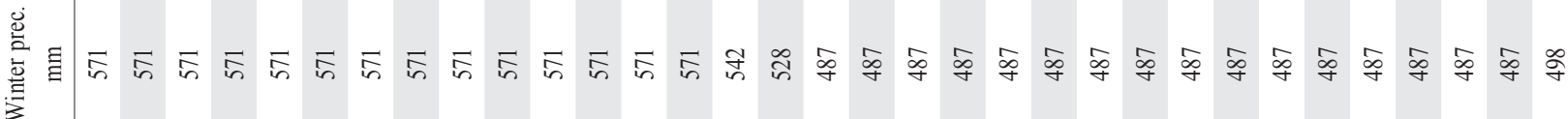

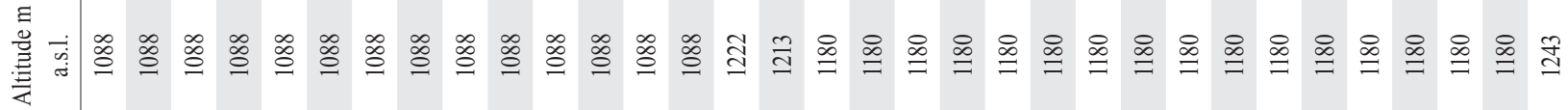

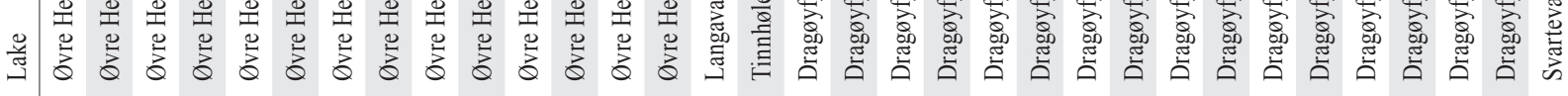

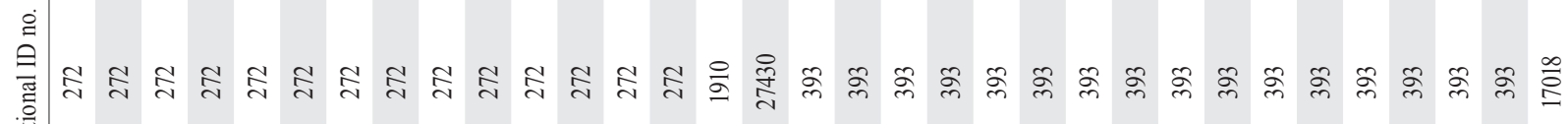
总

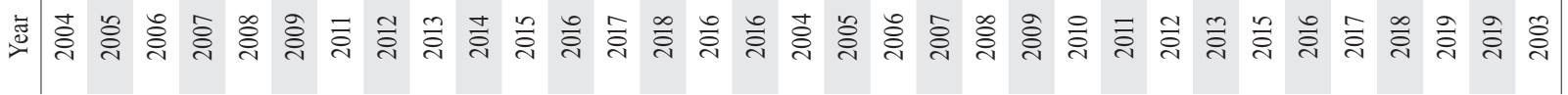




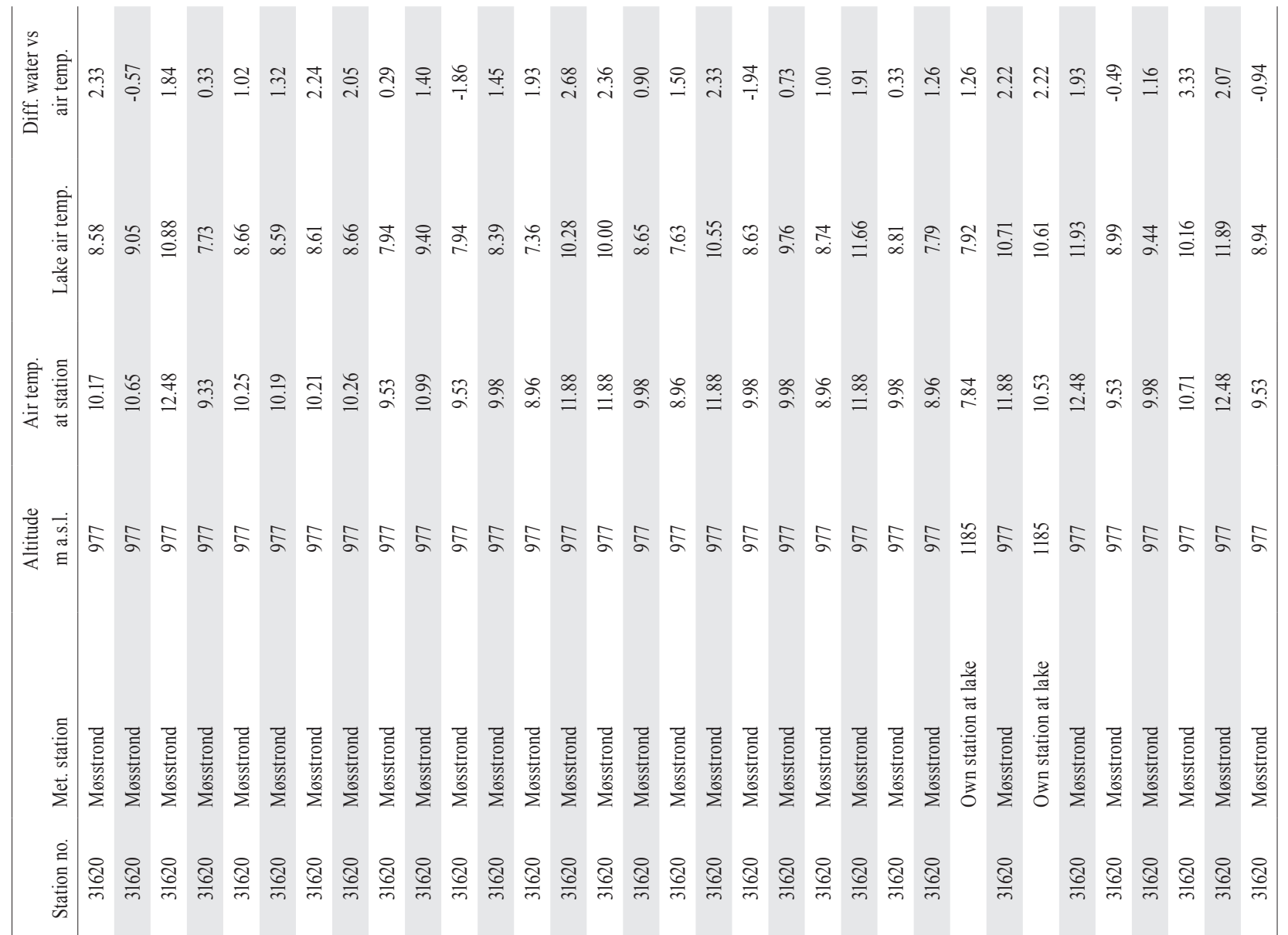

言

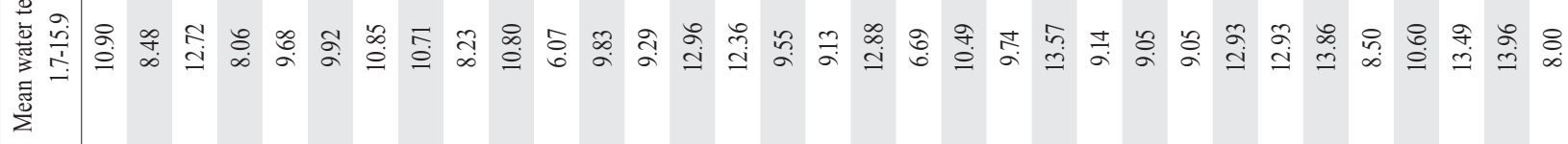

产

童

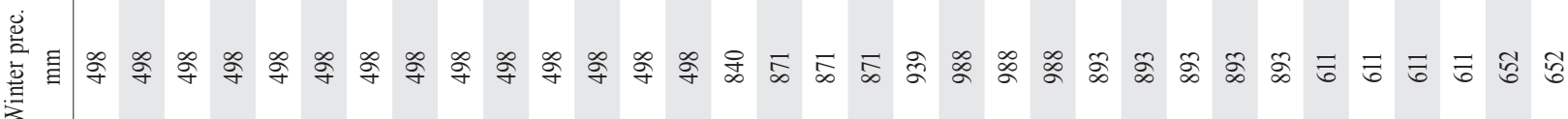
爱 


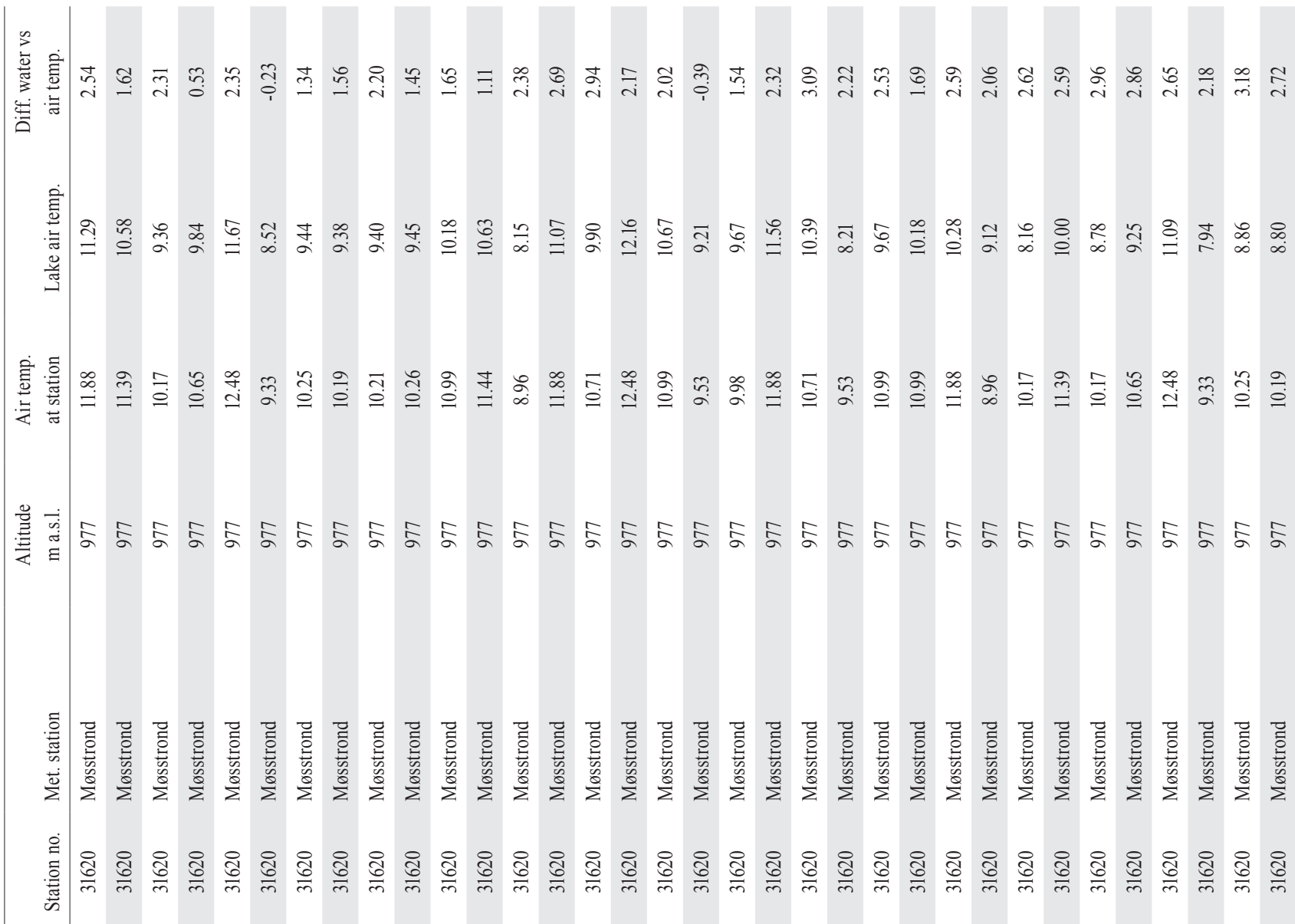

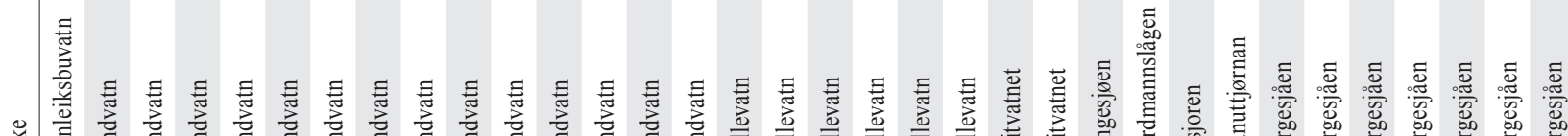

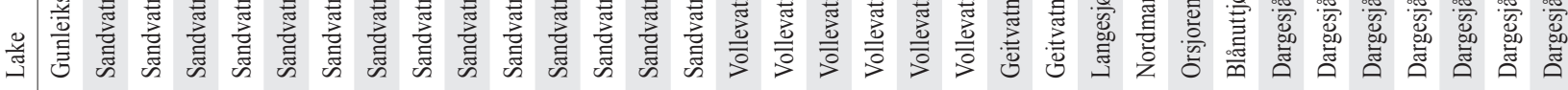

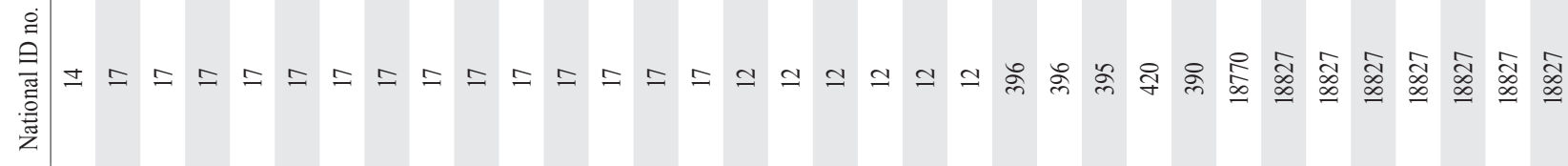

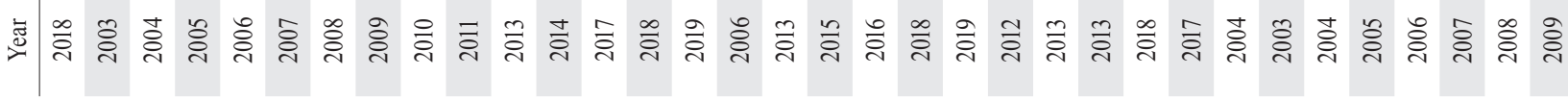




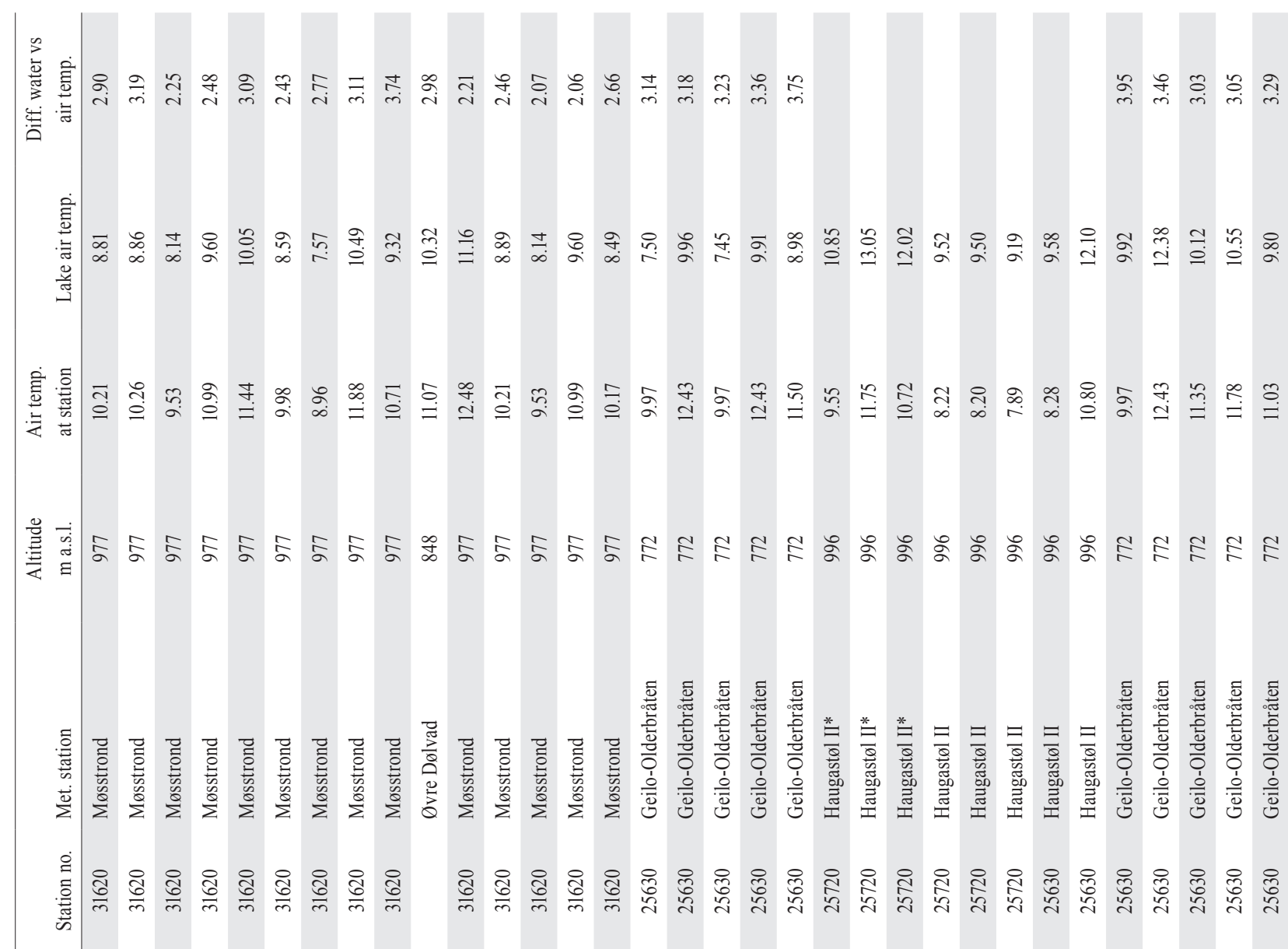

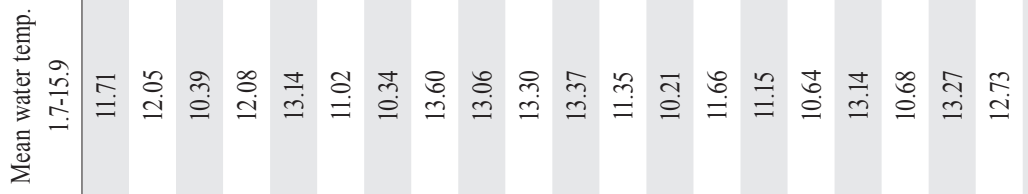

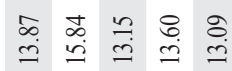

$\frac{\frac{2}{5}}{5}$ 意

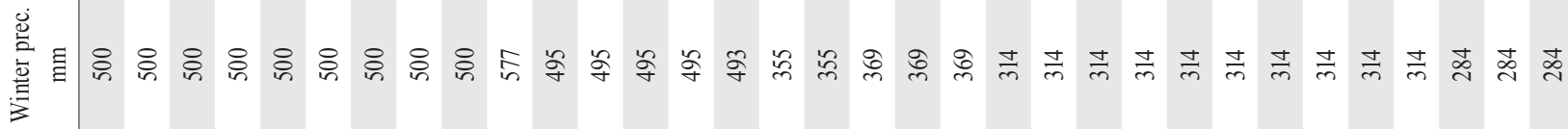

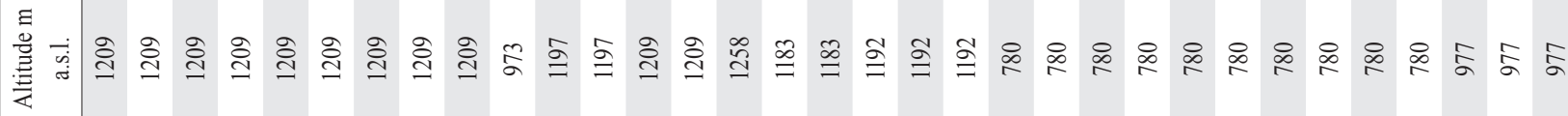

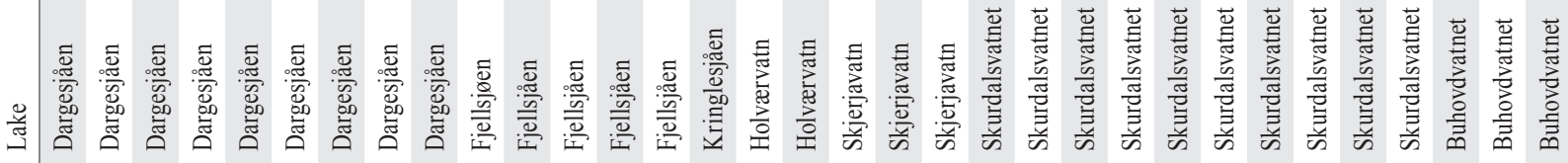

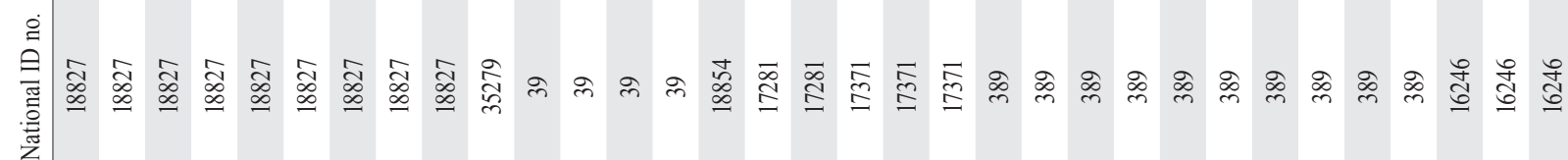

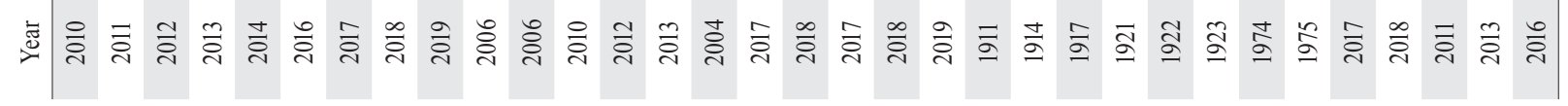




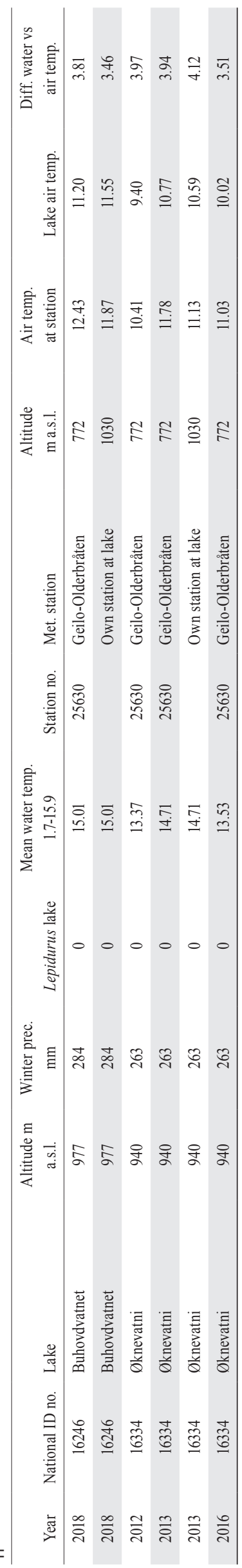

